University of Rhode Island

DigitalCommons@URI

Open Access Master's Theses

1997

\title{
Myths and Facts About Cluster Development: A Case Study of Two Rhode Island Towns
}

James A. Lucht

University of Rhode Island

Follow this and additional works at: https://digitalcommons.uri.edu/theses

\section{Recommended Citation}

Lucht, James A., "Myths and Facts About Cluster Development: A Case Study of Two Rhode Island Towns" (1997). Open Access Master's Theses. Paper 707.

https://digitalcommons.uri.edu/theses/707

This Thesis is brought to you for free and open access by DigitalCommons@URI. It has been accepted for inclusion in Open Access Master's Theses by an authorized administrator of DigitalCommons@URI. For more information, please contact digitalcommons-group@uri.edu. 
Myths and Facts About Cluster Development:

A CASE Study OF Two Rhode Island TownS

BY

JAMES A. LUCHT

A RESEARCH PROJECT SUBMITTED IN

PARTIAL FULFILLMENT OF THE REQUIREMENTS

FOR THE DEGREE OF MASTER OF

COMMUNITY PLANNING

UNIVERSITY OF RHODE ISLAND

1997 


\title{
MASTER OF COMMUNITY PLANNING
}

\section{RESEARCH PROJECT}

\author{
OF
}

\section{JAMES LUCHT}

Approved:

Major Professor

Acknowledged:

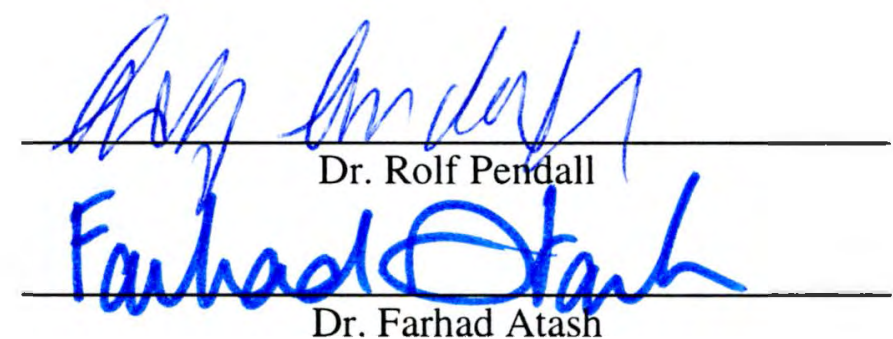




\section{ACKNOWLEDGMENTS}

I would first like to express my appreciation to my Major Professor Rolf Pendall, for helping me with this project and teaching with such incredible energy, enthusiasm, and devotion. I also give great thanks to my readers CPAD Director and Associate Professor Dr. Farhad Atash and Planning Director Richard Youngken of the Newport Collaborative Architects. Dr. Atash's patience and encouragement was very helpful to me in this arduous process, and Rich Youngken's hard work and enthusiasm is an inspiration for planning in Rhode Island.

A special thanks to Jennifer McCann and Virginia Lee of the University of Rhode Island Coastal Resources Center, where I did much of the background research for this project.

I also thank all of the professors, Suzanne Benson, and my fellow students at CPAD for their devotion to "Planning," that oft forgotten vocation.

Finally, I would like to thank Portsmouth Town Planner Bob Gilstein, Council President Byron Hall, Planning Board Secretary Glen Russell, and the rest of the people involved with making "Residential Open Space development" a reality in Portsmouth, RI. 


\section{TABLE OF CONTENTS}

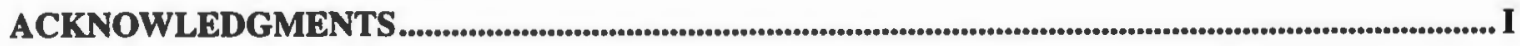

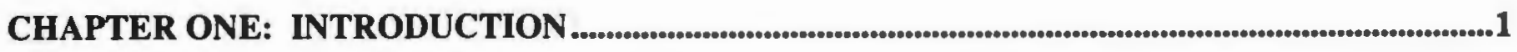

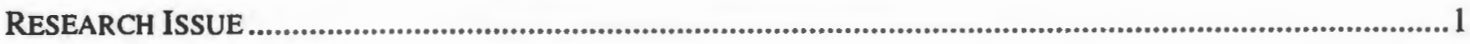

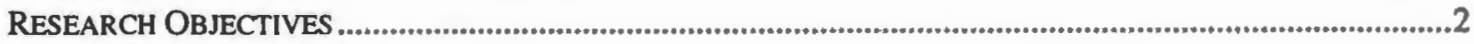

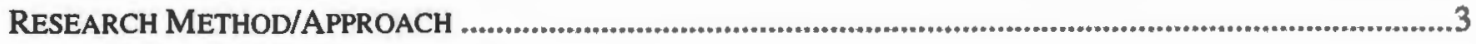

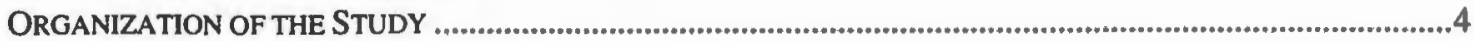

CHAPTER TWO: LITERATURE REVIEW

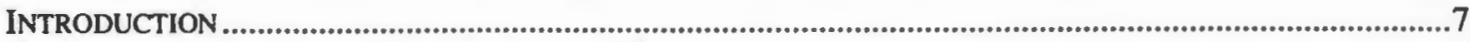

HISTORICAL CONTEXT: $19^{\text {TH }}$ AND EARLY $20^{\text {TH }}$ CENTURY ROOTS..................................................... 10

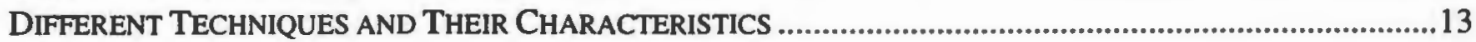

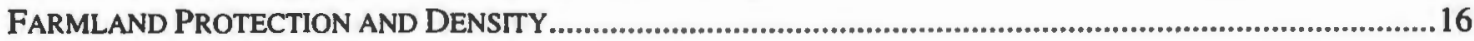

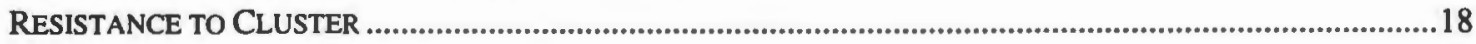

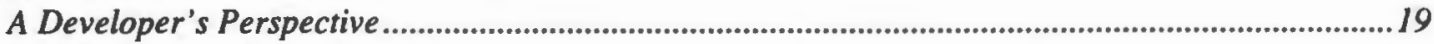

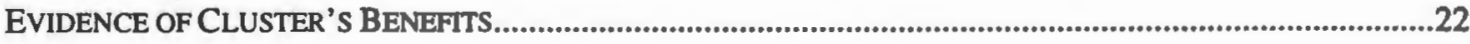

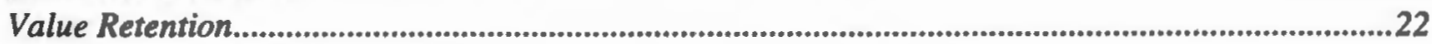

Comparison of Development Costs....................................................................................................223

CHAPTER THREE: METHODOLOGY..............................................................................................................25

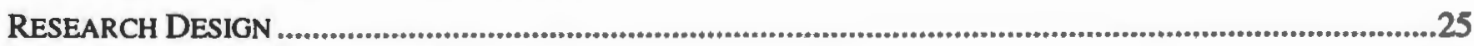

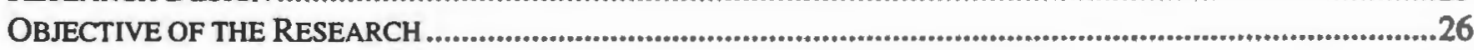

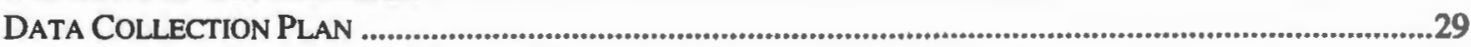

Materials Review List and Strategies:..........................................................................................................................30

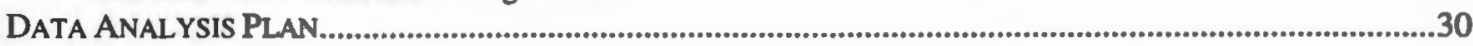

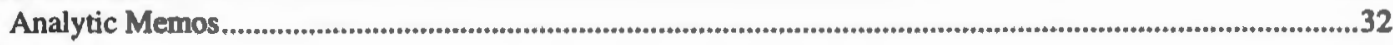

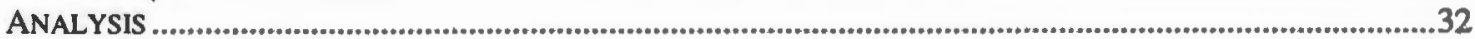

CHAPTER FOUR: TOWN PROFILES.......................................................................................................33

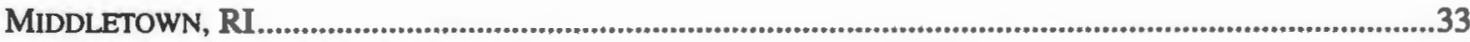

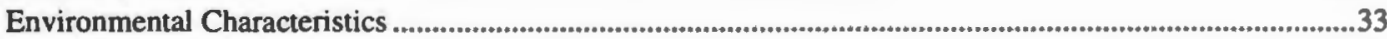

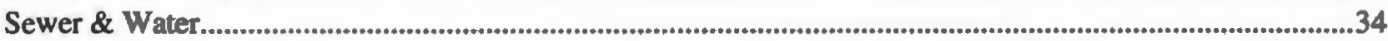

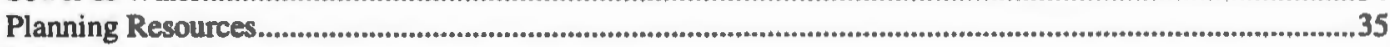

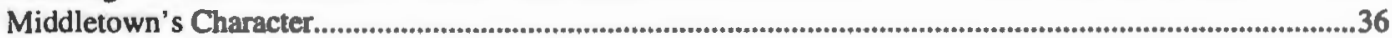

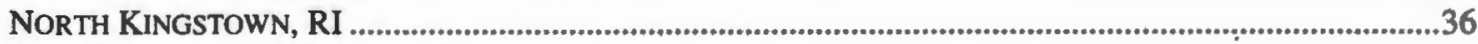

Environmental Characteristics ..........................................................................................................................................37

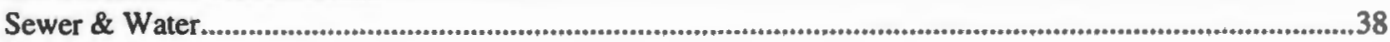

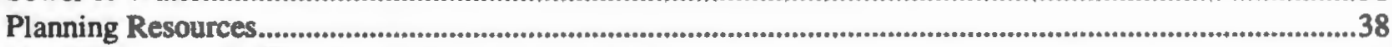

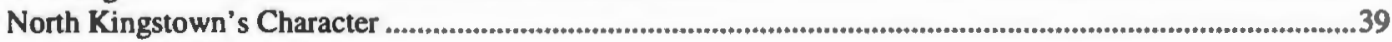

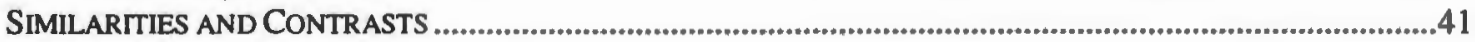

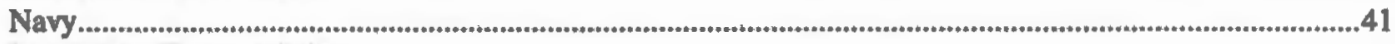

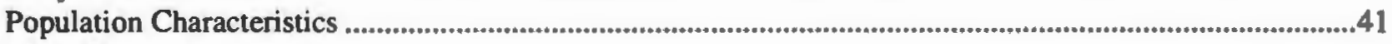

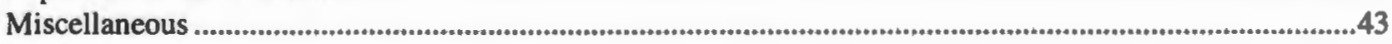

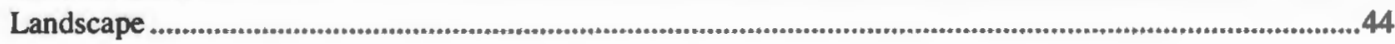

CHAPTER FIVE: DEVELOPMENT PROJECT PROFILES ...................................................................46

BROOKSIDE AT QUIDNESSETT ..........................................................................................................46

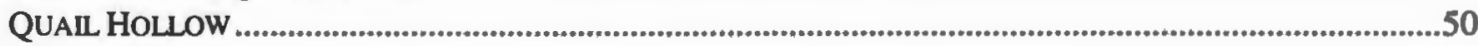

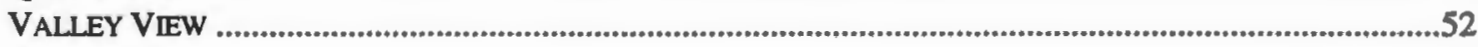

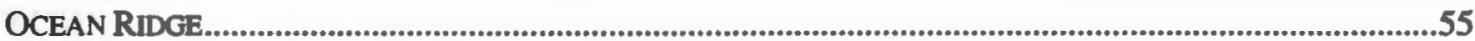

CHAPTER SIX: INTERVIEW RESULTS ...................................................................................................62

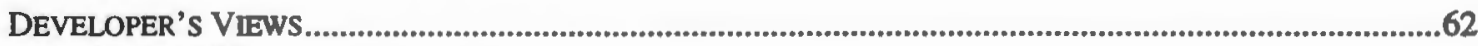

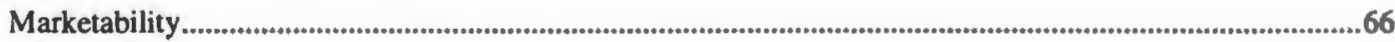


"The Path of Least Resistance" ..................................................................................................................69

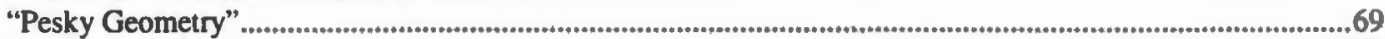

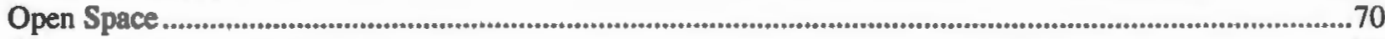

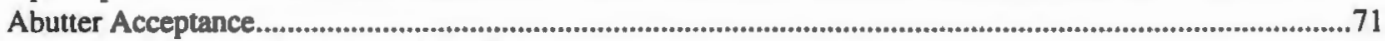

PLANNERS' AND BOARD MEMBERS' VIEWS ..............................................................................72

North Kingstown Planning Views ...................................................................................... 72

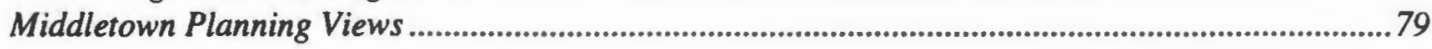

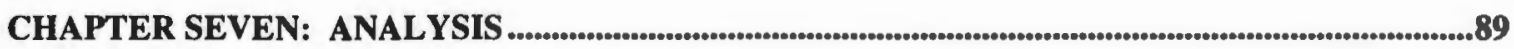

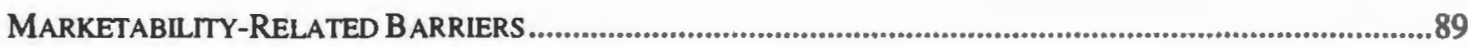

Homeowner's Associations .............................................................................................................89

House Size Limit ....................................................................................................................91

Developer Inflexibility ..................................................................................................92

Excessive Regulation ....................................................................................................................94

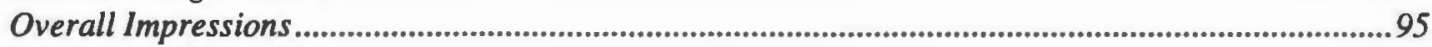

INSTITUTIONAL B ARRIERS ..................................................................................................95

Development Regulations .....................................................................................................95

Cluster as Stimulus for Development..................................................................................................97

Incentives ...................................................................................................................................98

Disagreement Between Town Departments .....................................................................101

General Questions ............................................................................................................102

Board Attitudes ...............................................................................................................103

The Most Prominent Barrier........................................................................................... 106

CHAPTER EIGHT: RECOMMENDATIONS..........................................................................107

HOMEOWNER'S ASSOCIATIONS ......................................................................................... 108

Buyers Concerns (Anticipated by Developers) ................................................................ 108

Coercion............................................................................................................................................. 108

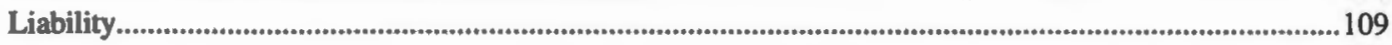

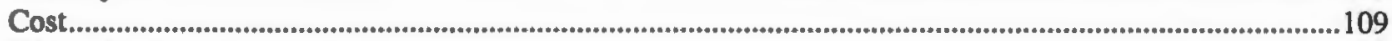

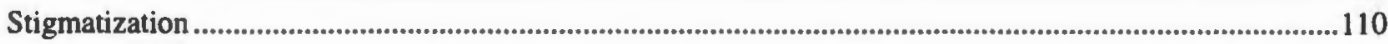

Town's Concerns ,.......................................................................................................111

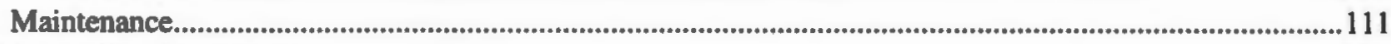

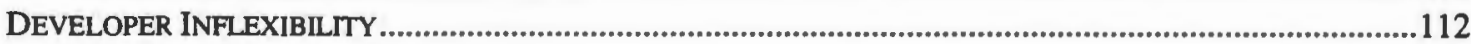

House Size Limit ..............................................................................................................112

Privacy ........................................................................................................................112

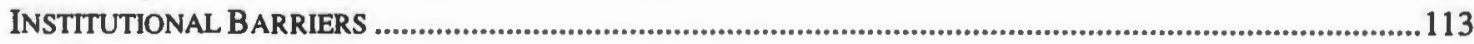

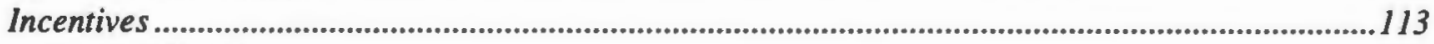

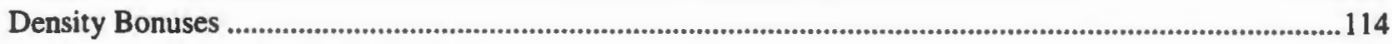

Development Regulations ..........................................................................................115

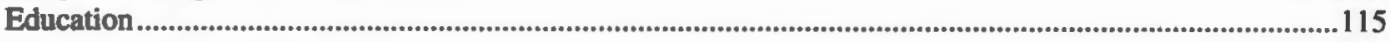

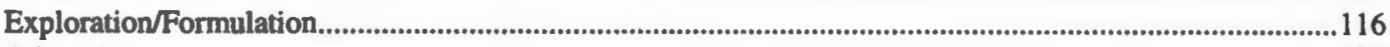

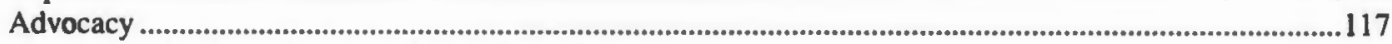

Lack of Coordination Between Town Departments ...............................................................118

Modified Standards..............................................................................................................................119

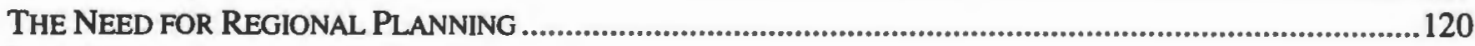

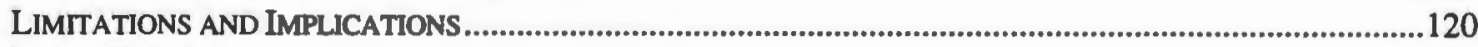

FINAL NOTES ................................................................................................................. 121

APPENDIX ONE: FIGURES

REFERENCES AND BIBLIOGRAPHY 


\section{CHAPTER ONE: INTRODUCTION}

\section{Research Issue}

Residential cluster development has been an option in many Rhode Island municipalities for many years. Despite this, many towns in Rhode Island fail to use the techniques much of the time. This failure raises questions, considering all of the benefits that supposedly result from creative development, especially protection of water resources and community character, goals which are often articulated in comprehensive plans. Conventional-style subdivisions continue to be the dominant form of residential development, and most present regulations could do much more to preserve rural character or protect water quality. Why are planners and boards not adopting regulations that could significantly advance their stated goals?

This research project is the result of my urgent curiosity to know why seemingly desirable potential good doesn't come to fruition. The "cluster" development technique is not a new idea. It seems to present an opportunity to develop land in a more environmentally and culturally sensitive way. It is used very effectively in many places under different conditions. So why isn't it considered the universal standard technique in Rhode Island where it is physically appropriate? If a town is dissatisfied with how it is being developed, shouldn't its planners and decision-makers be motivated to change in order to 
get what is most beneficial and fair? Is the ideal of sensitive development obtainable in the real world of dollars and cents?

Unfortunately it is not as simple as writing new regulations. Rather, towns have to promote clusters. But issues of fairness, balancing priorities, and design make such pro-activity complicated. The fundamental regulatory issue, as in much of planning, is how a town can regulate the unscrupulous while providing the flexibility necessary for creative design. As the reader will see, the local board's attitude seems to be the most significant factor in success. Attitude must feed into education, which in turn further affects attitude. Advocacy by the board is essential because the act of changing development trends involves personal and political debates, requiring powers of persuasion augmented with technical prowess and visual explanation.

\section{Research Objectives}

The research project will attempt to determine the most prominent perceptions towards cluster development in Rhode Island, and how these perceptions promote or discourage use of more innovative residential subdivision design methods. The research will focus on perceptions and attitudes related to cluster held by professional planners, planning board members, and developers. While the attitudes themselves may not always be barriers, planners attitudes and their perceptions of both tangible and intangible 
aspects of projects affect what types of land development policies they advocate. This advocacy or its absence influences the types of ordinances a town will adopt, as well as how its planners will educate their boards.

No studies up to now have specifically measured attitudes or perceptions of individuals involved in cluster development. The aim of this study is to begin to fill that gap. It will attempt to determine the nature, strength, and origin of each perception, and then sort the perceptions hierarchically according to frequency of occurrence and importance in the decision making process. It concludes with recommendations for clearing up misapprehensions and overcoming genuine barriers.

\section{Research Method/Approach}

This study uses a qualitative, exploratory case study approach. It studies examples of conventional and cluster subdivisions in North Kingstown and Middletown, RI. One project of each type is reviewed in each town, and planners, board members, and developers connected to each case are interviewed. Prominent perceptions and potential barriers are identified and substantiated with examples from interviews and case studies. 


\section{Organization of the Study}

The literature review (Chapter Two) outlines the historical roots of cluster development from the planned residential communities of the nineteenth century to the environmentally sensitive and community-character-saving subdivision design techniques that developed in response to unrestrained suburbanization. It also covers the recent debate over cluster's usefulness in farmland preservation, which highlights the need for regional planning with appropriate densities. This is an important issue in Rhode Island, where agriculture is in a steady decline. Finally it discusses investigations of barriers to cluster development, as outlined by Wyckoff (1992) and Arendt (1994) from the planner's perspective, and Lloyd (1965) on the developer's side.

The project's qualitative case-study methodology is outlined in Chapter Three. This interview and record-review technique proved interesting and effective, firmly substantiating some initial theories and presenting new issues.

Chapter Four describes the physical, demographic, and institutional context of the two subject towns. It illustrates similarities and important differences that directly affect conservation priorities, the usefulness of certain design techniques, institutional capacity, and political climate.

The case studies are introduced in Chapter Five. One cluster and one conventional subdivision from each town are examined. The cluster examples do not represent the "cutting edge" of context-sensitive design techniques, but 
rather illustrate typical projects in each town, and how town goals and developers wishes synthesize in what is built.

Chapter Six describes perceptions of cluster as expressed in interviews with planners, board members, and developers related to the cases in the previous chapter. Their words revealed a great deal, pointing to the connection between attitudes and results. The chapter sheds some light on the developer's perspective, which is essential to understanding their reactions to town demands. It also reveals some individuals' dissatisfaction with cluster's results and desire to get something more from their development regulations.

Chapter Seven is an analysis of the interview content in the general context of the case studies. Potential issues, or "barriers," are divided into two major areas. Market issues involve hesitation by the developer to do a cluster subdivision because they either think the process is too expensive or the product is undesirable. Institutional issues involve the capacity of the planning department and board, or nature of the regulations or process. Institutional issues seemed to contain more actual barriers, while marketing issues arose often in conversation but in the final analysis do not seem to present a substantial barrier to cluster.

The last chapter presents recommendations for overcoming the most prominent barriers revealed by the analysis. The most prominent marketing concerns involved homeowners associations and lot sizes. Developers can address these concerns through careful establishment of associations and 
thoughtful design. Both measures must be attuned to the market through thorough research.

Institutional barriers are more difficult to overcome. Education and extensive advocacy are required to develop appropriate regulations and processes. Incentives are a powerful tool for towns to get what they want, but their demands have to be economically feasible.

Resistance to change seems to be a prominent human trait. But the resistance to change manifested by communities in active anti-development attitudes and passive "head in the sand" denial may result in resistance to regulatory and procedural changes that would give them more power to shape development according to their aesthetic, ecological, and social preferences. The choice is up to the planners and boards. They not only are in the best position to begin the necessary changes, but they also are absolutely essential to overall success. 


\section{CHAPTER TWO: LITERATURE REVIEW}

\section{Introduction}

A house in the country has been an ideal for many generations. This ideal has drawn a large portion of the U.S. population to the countryside, creating a landconsumptive suburban development pattern on almost every urban fringe. Since the 1960 's, the general public has developed a greater awareness of the need to protect the natural environment, preserve open spaces and agricultural lands, and respect natural landmarks and historic and cultural features.

A municipality's protection priorities are manifested in what type of alternative development options it makes available and how its particular regulations are written. These priorities may be community character, open space for active or passive recreation, farmland protection, natural area protection, watershed protection, or infill development. For example, a town may prioritize protecting its rural character by placing minimum setbacks, requiring the retention of stone walls and mature trees, or adopting "right to farm" provisions. Another town might require open space to connect to planned future greenway networks. One valuable technique that can help further these goals is cluster/open space zoning.

Although residential cluster development has been an option in many Rhode Island municipalities for many years and the State Enabling Acts were rewritten in the early 1990 's to be more accommodating to cluster development, the 
technique is not used very often. For example, even though their comprehensive plans put high priority on preserving rural character, the Rhode Island towns of Exeter and West Greenwich have no cluster provision in their ordinances. On the other hand, Scituate and Portsmouth have recently adopted "cutting edge" open space zoning provisions. Municipalities in Massachusetts and Pennsylvania have included the option of using sophisticated cluster development techniques in their regulations for a few years, and many of these projects have been built (Arendt 1994; Corser 1994).

Even though good examples of these developments exist and there are many popular sources of information on the topic, creative development techniques remain the exception rather than the rule in many communities. Why is this the case? The answer must lie with individual and collective preferences and prejudices of planners, board members, developers, and citizens. These preferences and prejudices are based on knowledge, experience, and a resulting level of comfort with unconventional subdivision techniques. Unfortunately these perceptions, even when based on sound experience, can create barriers that preclude the use of a whole class of effective development techniques. The research question for this project is "what are the most prominent barriers, real and perceived, to the use of more innovative open space and community character-saving residential subdivision design methods?"i

A great deal of literature has been produced since the late 1980's regarding creative development techniques, but most deals exclusively with technical 
rather than social aspects of this development type (Arendt 1994,1996,1997; Yaro 1988; Young 1995; Porter, et al. 1988; Porterfield and Hall 1980; Knack 1990,1991; Heyer 1990). Most explain what to include in the zoning ordinance, such as procedures, performance standards, density calculations, dimensional flexibility, architectural standards, and septic requirements. Some explain the benefits of cluster using both systematic and anecdotal evidence. Others explain where the technique is most appropriate, or attempt to illuminate cost or marketability issues.

Only three sources treat "barriers" to cluster specifically. Rural by Design (Arendt, et al. 1994) anticipates many objections to cluster and proposes specific design and procedural solutions. It uses a series of real and hypothetical case studies to illustrate major concepts. Mark Wyckoff (1992) briefly outlines what seem to be the foremost obstacles. Lloyd (1965) examines barriers from a developer's perspective. While these and many other sources are excellent resources, they clearly come from an advocacy position and fail to systematically address the full range of real and perceived barriers in an "objective" manner. This project will help shed light on some of these barriers through literature, case studies, and interviews. But first, where did the conception of the "ideal residential environment" come from? 


\section{Historical Context: $1^{\text {th }}$ and Early $20^{\text {th }}$ Century Roots}

The ideas of common open space, harmony with natural surroundings, and single-family homes in close proximity have all been utilized in suburban areas for well over one hundred years. The ideal of suburbia has always been a blend of the best of both the urban and the countryside. The product of this striving has taken many forms. Residential subdivision design can all be seen to fall somewhere along a continuum. At one end, there is the conventional "cookiecutter" layout with typically rectilinear streets and lot lines, with the only open space existing in private backyards. At the other end, there is the "ideal" with curvilinear streets lined with mature trees, mixed with tasteful housing types with varying setbacks, and at least some shared or public open space.

With every pursuit of ideals, there have been varying levels of success. One significant attempt at the ideal is Frederick Law Olmsted's Riverside, first planned in 1868. Unlike the earlier planned community Llewellyn Park, Riverside did not merge lots into a continuous landscape. Almost half of the project's 1500 acres was to be common open space (Fishman 1987; 130).

Olmsted's idea was not exactly original, however. He was heavily influenced by Uvedale Price and William Gilpin's seminal works on the English picturesque, epitomized by the early London suburbs.

This idea of a "cottage in the garden" was even further advanced by the brilliant but sadly misunderstood Ebenezer Howard. Initiator of the garden cities Letchworth and Welwyn, Howard is often thought of as a physical 
planner, but he actually advocated physical planning to obtain radical social goals. He envisioned his creations as "merely the vehicles for a progressive reconstruction of capitalist society into an infinity of cooperative commonwealths" (Hall 1988: 87). While this was of course a socialist idea, it was tempered by Howard's rejection of centralized authoritarian government control that subordinated the will of the individual to that of the group (Hall 1988: 91). Howard's creation, Letchworth, was initiated in 1903 but was very slow growing. It was eventually completed with the help of Raymond Unwin and Barry Parker, who are also known for their earlier garden village of New Earswick, where they worked out many of the designs they were to later use in Letchworth (Hall 1988: 97).

New Earswick was bounded by a greenbelt which hosted both active and passive recreational opportunities, and laid out single family homes around common open space and pedestrian paths. It also contained a village green and "folk hall" community center, and even used culs-de-sac in later stages; it integrated natural features throughout (Hall 1988; 99). New Earswick had what Unwin and Parker called "reposefullness," a calming quality for which any planned residential community should strive. One common feature with all of these planned communities was lack of affordability and accompanying exclusionism. Even where housing for the working class was provided, it was set off from that of the higher classes (Hall 1988: 101). The garden city idea was also pursued at Suresnes in France and very well in Margaretenhohe in Germany 
which was "essentially a garden suburb at the end of a tram line" (Hall 1988:

115). This seems to have been a precursor to Peter Calthorpe's (1993) "pedestrian pocket" concept, a dense pedestrian and transit-based development design.

Another example of this concept, this time back in America, is Henry Wright and Clarence Stein's Radburn. Started in 1928, Radburn used a superblock design combined with cluster housing and measures to exclude automobile traffic. It was the first planned community to use a hierarchical road arrangement. Its general configuration was of modest houses clustered along short culls-de-sac, with pedestrian and bicycle paths equipped with underpasses. Stein also consulted on two similar projects Chatham Village in Pittsburgh (which had low rent and was close to jobs), and Baldwin Hills Village in Los Angeles, both of which were very successful (Hall 1988; 127).

Finally, no survey of the roots of clustering would be complete without mentioning Rexford Guy Tugwell's greenbelt cities of Greenbelt, Maryland, Greenhills, Ohio, and Greendale, Wisconsin, begun in 1935. These projects were characterized by swaths of open space and four to eight houses per acre, with priority put on pedestrian access (Hall 1988; 130). All of these later projects reflect an earlier tradition, and are related to subsequent cluster developments through shared amenities, common open space, unified design, and sensitivity to site characteristics.

Just after the Second World War, the United States experienced an incredible housing boom that completely changed both the American landscape and the 
normative expectations of subsequent generations regardless of class or creed. This post war boom left no time for the developer to be sensitive because of the overwhelming demand for inexpensive, mass-produced housing (Jackson 1985).

With the 1960 's came a new environmental awareness that raised concern for wetlands, forests, rare species, and other ecological values. Planning adopted an environmental dimension. The essence of this movement is epitomized in the work of Ian McHarg, who in his seminal book Design With Nature linked ecology to planning by illustrating concepts and techniques of environmental suitability analysis and development based on carrying capacity (McHarg 1967).

Landscape architecture became more common in residential site design as legally protected ecological values and aesthetics became important considerations to a new group of middle-class home buyers. Cluster zoning in its various forms is planning's response to these influences, as conventional subdivision just did not have the flexibility to deal with environmental constraints and aesthetic longings.

\section{Different Techniques and Their Characteristics}

Cluster Development: "A development approach in which building lots may be reduced in size and buildings sited closer together, usually in groups or clusters, provided that the total development density does not exceed that which could be constructed on the site under conventional zoning and subdivision regulations. The additional land that remains undeveloped is then preserved as recreational land." (Listoken \& Walker 1989).

Clusters can be both single-family and attached unit, and can range from as few as a half-dozen to hundreds of units. Standard cluster saves between twenty and forty percent of the open space on average, and some ordinances provide 
density bonuses as an incentive. Areas with wetlands, severe slopes, and bad soils are typically subtracted from the developable area and only a limited amount of these constrained areas can be included in the open space. Density is often determined by a yield plan, which determines how many houses can fit on the particular site in a conventional subdivision scenario considering development constraints. Under the broad term "cluster development," there are a number of related terms that describe its various manifestations.

Planned Unit Development (PUD) describes a technique that has been used in various forms for many years. PUD's are closely related to cluster, in that they both use a concept called "density zoning." In this process, the developer gains flexibility in design by varying lot sizes and sometimes housing types to preserve areas of open space, while the density proscribed by underlying zoning remains the same. Residential clustering is one of the techniques used in PUD's, but the latter usually include a mix of uses. In addition, PUD's are seen as a modification of existing zoning rather than a technique used within existing zoning (Rohan 1996: 12-32). They have the advantage of having no lot lines or very flexible lot lines that allow creative and sensitive site design. PUD's have similar issues to residential clustering with individual lots, but are not treated specifically in this project because they have different origins. Residential clusters are more a continuation of the garden suburbs of the nineteenth and early twentieth centuries, while PUD was more of a response to single-use autooriented suburbia of the fifties and sixties (Bookout and Wentling 1988). 
Open Space Zoning or Open Space Development Design (OSDD) is a unique form of development advocated by individuals such as Randall Arendt (1994), Robert Yaro (1988), and others. It requires conserving at least fifty percent or more of the land in a development as open space, while striving to preserve scenic, historic, and ecological values identified in the initial planning process. The ideas upon which it is based are not new, but the specific steps in the process are contrary to those typically taken in a conventional subdivision. First, all scenic, historic, and ecological values are identified and the most inappropriate areas for development are determined. From what is left, the most appropriate areas are designated for house siting according to views, physical context, etc. Density remains the same as under conventional zoning, and a conventional "yield plan" is produced to determine the number of buildable units. After houses are placed, roads, driveways, and paths are determined. Finally, lot lines are drawn to fit in the most appropriate fashion. This progression differs markedly from the conventional subdivision process, where roads and lot lines are drawn first according to strict dimensional standards, and the housed are placed near the center of each lot without regard to context.

Other forms of creative development include "Neo-traditional" and Rural Residential compounds. Neo-traditional developments require relaxation of typical regulations to allow re-creation of compact traditional pedestrianoriented neighborhoods with small lots and setbacks (Handy 1991). Remaining open space can then be used as formal parks with both active and passive 
recreation. Rural residential compounds are an alternative subdivision technique where a handful of lots are typically developed at very low density utilizing a narrow, unpaved private road with minimal drainage provisions.

\section{Farmland Protection and Density}

An important debate regarding the effects of cluster zoning and its usefulness for farmland protection was recently illustrated by two articles in the Journal of the American Planning Association. Thomas Daniels (1997) has serious reservations about using the cluster technique in agricultural areas, stating that it still leads to a dispersed settlement pattern and loss of prime agricultural land, and may not help at all to protect a community's working agriculture. He sees the main problems with cluster as excessive density, inappropriate location, and unreasonable expectations about what it will do. Daniels sees problems with limited development schemes as well (where the farmer develops only a limited number of units and sells development rights on the remainder so it can still be farmed), because even with the reduced density there is still potential for conflict between uses. He feels that open space/cluster zoning is in some cases "being offered as a quick fix for local... officials... who are faced with difficult choices as to how much development to allow, where the development should go, and who will make money from selling land for development." The only place he feels it 
might be appropriate is in rural fringes of weak farming areas, where it can create open space and provide small areas for low-impact high-value specialty crops.

Randall Arendt (1997) defends cluster, stating that the problem is not with the technique but with the predetermined density set by existing zoning. Arendt also states that criticisms of cluster based on past techniques are well founded. Both procedures and requirements were inadequate to conserve open space, historic or cultural settings, and visual amenities. He also admits that clustering "should not be seen as a farmland preservation technique, but as a way to save rural character and open space." Arendt states that cluster "is definitely a second best technique, if not third best" for farmland protection. He goes on to say that if people really want to save farmland, they have to implement agricultural zoning at around one unit per twenty-five acres. Two or three acre zoning simply will not preserve the large tracts of land needed for large industrial farming operations. Once the density issue is dealt with, the task is to "ensure that the pattern of distribution of that density... makes sense from the perspective of resource conservation." In addition to agricultural zoning for true farming areas, Arendt advocates limiting lot size to one or two acres and also governing location of residences to minimize potential conflict.

In areas that stand little chance of implementing agricultural zoning because of suspicion of "snob zoning" or emphasis on property rights (such as Massachusetts, Rhode Island, or Connecticut, for example), open space/cluster 
zoning might be the only effective way to protect substantial amounts of open space and farmland. Because of the denser zoning and high development potential, purchase of property or development rights is often too expensive for a community to save substantial amounts of land. Some preservation is better than none, and creative development techniques based on sound comprehensive planning can save large amounts of land that is going to be developed regardless. Low-impact agriculture can still occur adjacent to well-buffered residences.

In summary, planners should not tout open space/cluster zoning as an effective farmland preservation technique, but should advocate it when coupled with good comprehensive planning in areas where it is the most appropriate option. This seems appropriate in Rhode Island where it might be difficult to implement agricultural zoning, and agriculture probably would be considered weak when compared to places like Lancaster, Pennsylvania.

\section{Resistance to Cluster}

Considering the advantages and amenities of residential clustering, it is a wonder that cluster has not been universally accepted and applied. People resist cluster and build conventional subdivisions with no public open space and little consideration of environmental characteristics or community character. 
There are many potential reasons for this phenomenon. It could be regulatory barriers; the perception that a cluster plan will fail to go through; or boards or developers who project their own residential preferences on the public by restricting development types. These key players in the development process might feel that people simply do not want to live in a cluster situation. Other reasons might be fear of potential incoming groups of lower socio-economic status, lack of trust that local government planners and developers will do the right thing, fear that somehow the developer is getting more units than in a conventional development, or simple fear of something different.

\section{A Developer's Perspective}

Gerald Lloyd (1965) gives a very insightful look at the barriers a developer faces when attempting a planned unit development (PUD). He sees one of the primary obstacles as people's familiarity with single-family large-lot developments combined with an uncertainty about something new. Developers are familiar with construction costs and procedures, lender acceptance, and agency attitudes. Another main obstacle he sees is existing regulations and master plans, which he calls "bulwarks against the innovator." He sees a lack of trust from planners, boards, and abutters caused by suspicion of the developer's motives. Innovative proposals can also be seen as a threat to a politician or 
administrator that has to review them. These "guardians of the public good" see any flexibility as "a liberalization of the zoning ordinance."

Another threat to the developer is the vulnerability to legal challenge of any proposal that doesn't fit exact criteria. This works both ways, in that municipalities hesitate to put flexible elements into their regulations that developers might use to pose a legal challenge.

Other factors that weigh heavily on the developer are the time taken and changes made in negotiation (Lloyd 1965: 8). This is especially prevalent if the decision-making body is separate from the hearing body. Conditions and allowances made at the hearing are not always understood by the entity making the final decision. In Rhode Island, this may play out as the need for a zoning board's or Town Council's final approval on a PUD or zone change related to the project. Approvals also have to be attained from the health department, town engineer, solicitor, and fire department. Lloyd feels that oftentimes the planning board expects developers to obtain all of these approvals themselves, and sees no responsibility to advocate a mutually created design. Communication among all of these entities in the early planning stages is essential for a successful project. He states that PUD requires both a mature builder and a mature administrative system. Professional full-time staff to aid the board is essential in his opinion, as the planning board needs the expertise and communication skills of professional planners. 
Other areas where developers run into barriers to PUDs are in financing and production. Lloyd states, "Unfortunately, bankers have little experience with the valuation for mortgage purposes of environmental design, open space, common recreational facilities, and other comparable amenities" (Lloyd 1965: 10). This was his view in 1965, and it is probably true today. He gives an example of one of his development proposed with a four-acre park. The town loved it but the bank saw it as a "meaningless nuisance" and would approve of the project only if the town accepted dedication. Production problems stem from use of subcontractors. Here the familiarity problem arises again. Creative development may require subcontractors to deal with estimates on unfamiliar techniques, union issues, and initial lack of efficiency before they become familiar with new techniques and materials. They would also question the long-term benefits of learning specific new techniques.

The last major barrier Lloyd outlines is the "great gamble of market acceptance." Although the PUD concept has been around for many years, it is still thought of as a gamble. Towns almost insist that the project that they are approving be planned from start to finish. Once approved, change is a difficult prospect. Approvals are sometimes based on preliminary plans that do not take into account all of the possible factors that arise with actual construction. These factors can drive costs up or require substantial modification, both potentially affecting market acceptance. 
In summary, Lloyd believes that we need to "revamp our entire planning and zoning structure." He states that "When control stifles creation, it is time to throw the book away and rely on judgment, humanity, and basic standards to create a new framework for regulation." He calls for coordination of administrative authorities, professionalization of processing, and stronger regional planning to avoid localism. Last, he sees the need for more flexible, performance-based standards along with recognition of their legitimacy by the courts.

\section{Evidence of Cluster's Benefits}

\section{Value Retention}

Cluster has many benefits. First, cluster subdivisions seem to retain value. Jeff Lacy of the Center for Rural Massachusetts sought to determine whether cluster developments retained value as well as conventional developments by comparing cluster and conventional development in the Massachusetts towns of Concord and Amherst. Lacy found that for Concord:

"The prospective home-buyer, selecting residential property as an investment in 1980, would have received a higher rate of return on that investment in 1988 by purchasing the "average" home in Meriam's Close (the cluster), versus the "average" home in the Town of Concord as a whole. A home sale occurring in any year during that period, with the exception of 1982 , would also have produced the same result" (Lacy 1995).

For Amherst, Lacy found:

"The cluster/open space Echo Hill development exceeded its conventional counterpart, Orchard Valley, in open-market, sale-price appreciation during the 
period of 1968 to 1989 . Based upon this analysis, the purchase of the average home in the open-space community would have yielded a higher rate of return on investment than one in the conventional development, despite the nearly 2:1 lot-size differential."

He concludes that:

"Other studies have shown that proximity to protected open space and the provision of some basic recreational facilities enhances residential property value (Correll, et at 1978). This study suggests benefits that can transcend even a significant reduction in house-lot size: The design flexibility inherent in an openspace layout leaves room for integrating the undeveloped lands into and around the groupings of structures. This ensures ready access to considerably more open land than would be possible on a given, albeit larger, residential house lot. Finally, as this research indicates, the home-buyer, speaking in dollar-terms through the marketplace, appears to have demonstrated a greater desire for a home with access and proximity to permanently-protected land, than for one located on a bigger lot, but without the open-space amenity."

His conclusion seems to follow common sense. Preservation of natural amenities and ready access to large, permanently protected open spaces make a better and more desirable (therefore more valuable) environment.

\section{Comparison of Development Costs}

Clusters also offer advantages because they cost less on a number of factors such as utilities, site development, and some regulatory considerations.

Armstrong (1992) compared the development cost of five different types of development: a simple lot split (six lots), standard subdivision (forty lots), cluster condominium development (forty lots), subdivision with open space (six lots), and condominium with open space (six lots). She found that, as one might 
expect, the simple lot split was the cheapest alternative because it requires no road and drainage engineering or site improvements. Costs per lot for the standard subdivision and the cluster were almost the same, with the cluster actually coming in slightly cheaper (holding sanitary sewer and water costs constant). Some of the savings derive from avoiding legal cost to prepare plat documents and attain approvals. In the forty-lot developments the cluster provided substantial cost savings because of reduced infrastructure. While design costs are a large component of development costs, capital expenses for roads and utilities are more often the critical factor in a project's financial feasibility (Armstrong 1992: 10).

These savings could be increased if road width were reduced and different drainage options were allowed for private roads. Regarding septic waste disposal, individual systems are the cheapest alternative, short of connecting to a pre-existing municipal sewer. Clusters are less costly when sewers are required, again because they need less infrastructure. In conclusion, Armstrong feels that there is great savings potential in clustering, but return on investment relies on sales potential. Sales potential in turn relies on good design. She also feels that acceptance of cluster in rural areas relies on providing both aesthetic incentives to customers and residents, and monetary incentives to developers. The former relies on requiring good design and sufficient open space, while the latter might require reduction in private street and drainage standards or slight density bonuses. 


\section{CHAPTER THREE: MeTHODOLOGY}

\section{Research Design}

This research project uses a quantitative exploratory case study method to focus on issues related to four residential housing developments in two towns. It explores attitudes of individuals connected to cluster and conventional development projects in the Rhode Island towns of North Kingstown and Middletown. Sayer and Morgan (1995) state that "in all empirical research there is a three-way interaction between method, theory, and policy conclusions or evaluations." This philosophy is reflected in this project, and has ramifications in how data was defined, modified, and collected.

In-depth case studies are an excellent method for studying attitudes and perceptions because they allow the examiner to interact with the subject and ask penetrating questions that are easily avoided in other forms of research. In a narrow case study the interviewer has more time to get to know the subjects and their mannerisms, making it easier to derive an idea of the individual's true perceptions. North Kingstown and Middletown were selected for the study because they have both experienced rapid growth in the last ten to fifteen years and different levels of success using cluster development. 


\section{Objective of the Research}

The ultimate objective of the project is to identify the most prominent perceived barriers to the use of residential cluster development. "Prominence" in this study means how much those attitudes are detected during interviews and document analysis. The term "barrier" in this context means a perception that contributes to or is the sole reason for discouraging use of cluster development. I examine individual barriers within both their current and historical context.

The following is a preliminary list of issues that potentially foster negative attitudes towards cluster development. These are focused on first as a framework for exploration, leaving room for refinement, expansion, and discovery of additional issues, barriers, and related perceptions:

1. Lack of public and municipal board understanding of concept and benefits

2. Issues surrounding ownership and liability regarding preserved open space

3. Concern over market and value retention for cluster housing

4. Cost/ scale considerations

5. Issues surrounding density bonuses and other incentives

6. Administrative review difficulties, such as requiring a special permit

7. Putting the burden of proof on the developer that cluster is superior to conventional subdivision design

8. Hesitance to join a homeowner's association (affects perception of marketability)

Each of these issues is important and each may contain a number of different barriers that need exploration. Planners, other town officials, developers, and citizens may perceive them to varying degrees, and these perceptions may become stronger through interaction with others that have the same perception. 
In order to expose and illuminate these perceptions of barriers, I attempted to paint a picture of reality by providing information on both the technical and physical aspects of each case as well as position-based perception or attitudes (e.g. planners v. developers) and individual and collective meaning. It is important to provide this background so that the cases involved in the study can be easily compared and contrasted with other cases.

It is important to explain the historical and present context, and how it affects individual's perceptions regarding what they are comfortable with allowing in their towns and what they are not; this should be closely related to what they have allowed in the past and where these trends (if identifiable) are presently heading. This helps determine how much attitudes are based on actual past experience with cluster and how much is based on hearsay or unawareness.

The research process was open to modification along the way and receptive to unexpected discoveries and what interviewees say. This was both to create new conceptual categories and to modify existing categories. Some of the new or evolved categories are not fully exploreable within the scope of this project. The preliminary categories are explained below in the Data Analysis section.

Individual Cases: what I learned; why I learned it that way.

"Answers" to questions about the barriers appear in several different forms. Sometimes they are answers at face value to questions posed during interviews, subtle clues revealed through conversation and reaction to certain questions, 
comparison of past recorded accounts and current interview answers, disparity or agreement between parties on various issues, and how present perceptions are related to past experiences.

The proposed case studies present a variety of elements that will reveal a wide range of attitudes. I chose Middletown for the study because I had prior experience with Middletown's planning board regarding the cluster issue and have a general familiarity with planning issues there. I chose North Kingstown for the study because I was aware of its preference for cluster; over ninety percent of subdivisions built there since the early 1980's have been clusters (Whitaker 1997).

Both the Towns and the cases are very different. The Towns are different institutionally and have different histories of acceptance of unconventional residential development. They also differ demographically. Individual projects differ markedly as well, with Middletown's cases being much more modest than North Kingstown's, where both developments houses are in the $\$ 350,000$ $\$ 450,000$ range. While these cases are not comparable in certain aspects, they yielded valuable insights through this type of research. For example, North Kingstown's extensive use of cluster in the past and well-staffed planning department are likely to foster a different attitude towards the technique in planning boards, councils, and citizenry, in comparison with Middletown, which has not used the technique as extensively and has a single planner. 


\section{Data Collection Plan}

Although the literature review conducted for this project uncovered no studies specifically related to measuring perceptions, it serves as a good starting point for a technical understanding of the wide range of techniques, their associated benefits, and conditions of application. Literature was collected and reviewed throughout the project process.

For each case, I collected different types of data under three broad categories: background, process, outcome. Interviews with key informants were used throughout. "Key informants" are planners, developers, board members, council members, and citizens. Background includes a basic history of residential development in the towns and an analysis of socioeconomic status and residential mobility using 1990 census data. It also includes a brief history of the development site including past uses and development proposals. Process information included project file review, analysis of institutional capacity (workload v. staff resources), meeting minutes, zoning and subdivision regulations, and analysis of how negotiation over how to design around site opportunities and constraints. Outcome data includes final design, concessions, and information on homeowner's associations and maintenance agreements. For example, wetlands and stone walls are site characteristics that may affect the placement of homes in a development. Cluster provides the opportunity to design the development to protect or take advantage of these features by careful allocation of open space. How much this connection is made by the individuals 
doing the negotiation is an important indicator of their perception of cluster as a means to achieve these ends.

Materials Review List and Strategies:

Documents: Public domain documents were reviewed and contents summarized.

This helped to establish facts and process of the cases, as well as helped gauge attitudes where prevalent.

Literature: Literature was sought and reviewed throughout the process.

Audio: Recorded interviews were analyzed in detail. This is particularly important in gauging attitudes, as they may reveal content left out of the written minutes, as well as voice inflections that indicate strength of conviction.

Interview Strategy: Interviews were based on a set of standard themes, but not exactly the same questions as in a survey. I took care to focus on key questions, however, so I could gather a complete range of data.

\section{Data Analysis Plan}

Due to the amorphous nature of the subject of the research question, data analysis requires a very special approach. The process of conceptualizing, measuring, and evaluating attitudes requires a constant feedback process between organization and analysis. Considering this requirement, this project 
employed a standard data coding system leading into a successive approximation analysis.

\section{Coding}

Coding was used to consolidate and analytically categorize data. The initial coding scheme grouped data according to preconceived attitude categories, which were pared out or added to as the project progresses. Some examples of these categories were developer influences, or those of planners, decision makers, citizens, or neighborhood groups. Special attention was paid to data that crossed conceptual categories.

Data were coded using the standard open, axial, and selective sequence. This process was somewhat cyclical, with each periodic coding cycle building on the last as more data were collected. Open and axial coding occurred primarily in the initial cycles, where I established most of the final conceptual categories and established the order. The axial coding step was helpful to determine how the data would help answer the research question. Relationships were revealed by "multiple instances of empirical evidence," and efforts at further investigation were prioritized through this process (Neuman 1995: 424).

Finally, selective coding derived the major themes and helped determine the overall focus and structure of the final product. For example, major themes included fear of administrative difficulty by the developer and the dissatisfaction with open space configurations. 
Analytic Memos

Analytic memos were used to clarify concepts and relationships throughout data collection, coding, and data analysis processes. Memos were written on legal pads, and filed according to category with cross-reference notes.

Refinements were made on a word processor for ease of transferal to the final report.

\section{Analysis}

Successive Approximation was used to analyze data. Research began with a broad but concrete research question along with a pre-written framework of assumptions and concepts regarding stakeholders in the residential development process and their attitudes. The coded data were then reviewed to see whether the concepts were supported. Concepts were put aside or solidified according to evidence, and assumptions were confirmed or denied according to how they support or modify the concepts. After initial clarification, more research was undertaken in needed areas. As generalizations developed, they were refined to better reflect evidence (Neuman 1995: 428). This went on until a subject area was saturated. When all areas were saturated, the final analysis and synthesized write-up was performed. 


\section{CHAPTER FOUR: TOWN PROFILES}

Note: Maps are in Appendix A

\section{Middletown, RI}

Middletown is a socially and physically diverse community of approximately 19,500 persons (1990) located on Aquidneck Island in Rhode Island's beautiful Narragansett Bay. Its name is appropriate, as it occupies the middle of the Island with rural-suburban Portsmouth to the north and the bustling historic City of Newport to the south.

There are a handful of large employers on the Island, the most substantial serving needs of the Navy, which has installations spread throughout the three communities. Middletown's entire western shoreline is occupied by the Middletown Navy Base. While Newport has many auto-oriented commercial establishments, Middletown serves as the Island's main local commercial center due to its accessibility and proliferation of suburban strip commercial development along East and West Main Roads. Land use in Middletown was almost entirely agricultural until the military build-up before and during the second world war.

Environmental Characteristics

Middletown's topography consists of gently rolling hills and small valleys, becoming more gradual towards the southern and western parts of town. There 
are very few steep slopes and like much of New England, almost all of the town has been cleared for agriculture at some time. Most soils have severe limitations for ISDS because of slow permeability and wetlands. This is aggravated by the presence of a hard, impermeable fragipan layer which causes a seasonally high water table and potential lateral flow of septic effluent. The soils are excellent for agriculture and much of Middletown is cultivated for vegetables and nursery stock.

Bailey Brook, whose watershed contains the most heavily used commercial land uses, serves as a major conduit for most of the Island's drinking water supply. Clean water flows from reservoirs in Little Compton and Tiverton, through a pipeline under the Sakonnet river to reservoirs in Portsmouth, where some is distributed to customers in the north of the Island. It then is channeled south through Bailey Brook, where it inevitably picks up a host of contaminants, to holding reservoirs served by Newport Water Department treatment facilities. After treatment, water is distributed to customers in Middletown and Newport.

Sewer \& Water

All of the western half of Middletown is served by sewers, which extend substantially into the eastern half of town in two areas. The town does not plan to pay for sewer line extension, but capacity exists for developer-funded expansion. The town has a utility tax which they assess according to length of 
frontage served, which landowners may perceive as an incentive for development because they must pay whether the land is slated for development or not. In essence, the additional tax in a way reclassifies raw land as "land to be developed." Water service is less extensive, but still serves the majority of the western half of town. Private wells in some of central Middletown have had problems with pesticide contamination due to past agricultural use. All but one of Middletown's wells are in the south central section of town, which is still being actively developed.

Planning Resources

Middletown has a seven-member Town Council and a Town Administrator, Michael Embury, who has a master's degree in community planning. The planning board is a mixture of ages and occupations, consisting of two engineers, a marine construction contractor, a school teacher, a housewife, a contractor, and a lobsterman. The planning staff consists of the single town planner, Charles Silvia. The town has an extensive GIS system which is used for planning and assessing purposes. The town's comprehensive plan was accepted by the state in 1994, and includes many goals and policies that cluster development techniques can help further. 
Middletown's Character

Middletown's character has at least four distinct elements. In the western part of town, land use is characterized by the Navy Base with adjacent high density government and private housing and strip commercial development. Just to the east and spreading to the north and south is a growing band of mostly singlefamily detached houses, slowly consuming the town's remaining farmland. This farmland constitutes the third element of the town's character. Patches are cultivated throughout the town, but most are concentrated in the northeast. The eastern shore is dotted with small estates and vineyards, representing old money and new enterprise. The final element of Middletown's character is epitomized by its southern coastal beaches and Norman Bird Sanctuary/Sachuest Point, a large preserved natural area.

\section{North Kingstown, RI}

North Kingstown is a community of just under 24,000 (1990), situated on the western edge of Narragansett Bay. It is surrounded by East Greenwich to the north, Exeter to the west, and South Kingstown and Narragansett to the south. Like Middletown, development activity was closely linked with military activity. One major difference in development history, however, was the proliferation of mills and mill villages. North Kingstown has eleven distinct villages which are 
denser and have more diverse uses than the surrounding agricultural settlement. An overriding theme in the comprehensive plan in fact, is to pursue a "village planning concept" that promotes infill development and rehabilitation of old structures.

Similar to Middletown, Naval presence at Quonset Point and Davisville spawned considerable strip commercial development along Route 1. The Naval realignment in 1974 had a great impact on the town, reducing the population by 10,000 and dealing a major blow to the local economy (NK Comp. Plan; B 1-2).

The best known spot in North Kingstown besides Quonset Point is the seaside Village of Wickford. Starting out as a summer resort and point of departure for Newport, it now serves as the town center and a major tourist attraction.

\section{Environmental Characteristics}

North Kingstown is characterized by gently rolling hills, meadows, forests, and farms. This terrain creates many separate drainage basins (NK Comp. Plan; B 2-1). According to the town's Comprehensive Plan, "a vast amount of the community qualifies as prime farm land, and lies within the path of development" (NK Comp. Plan; B 2-2). Most soils have only slight to moderate development constraints, but there are a substantial number of wetlands, riparian areas, and floodplains. 
Sewer \& Water

There is no public sanitary sewer service in North Kingstown. A $2.3 \mathrm{mgd}$ capacity primary treatment plant serves Quonset Point and some adjacent high density residential developments, but the town and State have not allowed any new connections. The town is contemplating package plants and tie-ins with adjoining towns to serve high density village and commercial areas (NK Comp. Plan B 7-4).

North Kingstown's water system relies exclusively on groundwater drawn from the Hunt, Annaquatuckett, and Pettaquamscutt aquifers, with a maximum safe yield of $7.9 \mathrm{mgd}$.

Planning Resources

North Kingstown has a five-member Town Council and a Town Manager. The five-person planning department consists of the planning director Marilyn Cohen, Planners Ray Whitaker, Ed Pimentel and Pat Nickles, and Karen LaPolice, the long time Office Supervisor. The town does not currently have GIS capability, but desktop GIS is slated as the department's next big investment.

The town has overlay districts to help regulate for "development limitations," steep slope, groundwater recharge, groundwater reservoirs, and special flood hazard. The ordinance also provides for residential compounds and historic district zoning. North Kingstown's comprehensive plan was accepted by the 
state in 1995. The latest cluster ordinance was adopted in 1980; the original cluster ordinance was introduced in 1968 and amended in 1971. When asked why they thought North Kingstown has had a cluster ordinance for so long, both the board members and planners cited progressive thinking on the part of board members and strong conviction of past planning department personnel.

The present commission has a very high level of environmental awareness. It is comprised of design professionals: two highway engineers, a sanitary engineer, an architect, and a landscape architect.

The long-time chairman, Jim Dobson, recently retired. He is a service station owner and knowledgeable citizen planner who served as chair for ten years. The present chair is Mike Desmond, a private traffic engineering consultant who has served on the board for eight years.

\section{North Kingstown's Character}

The town's agricultural and mill history provides an interesting mix of landscapes. In a survey performed as part of the comprehensive planning process, residents expressed that they liked the town most because of its "clean, country-like living" and "its location in the State and ... by the water." They also felt "most concerned about continuing development that may erode the small town atmosphere." 
The several major elements of the town's character include the waterfront village and estate, the old farm (epitomized by Casey Farm on Route 1A), eyesore strip commercial along Route 1 , scattered medium and low density residential developments, historic mill villages, and small forested hilly areas. Most of the residential development is along the town's main collector streets or along the coastline (NK Comp. Plan B 4-1). The advent of scattered subdivisions is changing this pattern as many former agricultural fields are developed as lowdensity upscale housing.

There are some high-density developments adjacent to Quonset Point that are served by the former base's utility network and sewage treatment plant. Agriculture is still active in a handful of locations for general crops, and there is a thousand-acre turf farm in the southern end of town. According to the comprehensive plan, all of this land is under continuous development pressure. Commercial development is mostly along Post Road (Rt. 1) and is a concern due to lack of sewers, which would handle commercial effluent better than septic systems. Most of the major mill structures are gone, but much of the accompanying development remains, providing compact areas of affordable housing. 


\section{Similarities and Contrasts}

Navy

Both towns have been affected by Naval presence since the Second World War. The needs of military personnel helped spawn strip commercial development on major roads close to the bases. There is still a substantial Naval presence in Middletown, but all that remains in North Kingstown is an Air National Guard facility in part of Quonset Point. The rest of the Quonset facility was turned over to the state and is used as an industrial park. The Davisville portion of the facility will come under state control within the next year.

Population Characteristics

North Kingstown has three distinct areas of high socioeconomic status, where Middletown has only one large area taking up the eastern half of the town. North Kingstown has four areas of highest home values, where in Middletown it is concentrated in the eastern half, with the exception of a small enclave in the northwest corner of town. This area is unusual in that it has high income and home values coupled with low levels of college education and professional/managerial status. The reason for this may be that it is home to high ranking Navy officers.

North Kingstown has a higher percentage of population born in Rhode Island, spread liberally throughout the town. Taking into account percentages of 
persons moved in before 1960 and after 1984, North Kingstown has a much less mobile population than Middletown. The only area in Middletown where over half of the population were born in Rhode Island is a small, dense neighborhood on the Newport border. This neighborhood also has many pre-1960 and fewer post-1984 residents. The eastern half of Middletown also has these latter characteristics, but with a lower native Rhode Island population.

One area of North Kingstown, Saunderstown, has the least mobile and highest socioeconomic status of either town. There is some overlap of low mobility in other rich areas of North Kingstown. A notable exception is the area in and around Wickford, which has many newcomers of high socioeconomic status. Considering the character of the area, this suggests gentrification of neighborhoods in the historic center.

Middletown on the whole is much more residentially mobile than North Kingstown. This may be because of higher availability of affordable housing in Middletown. This assumption is supported by its lower median home prices and income compared to North Kingstown.

In sum, the spread-out pattern of high socioeconomic status and low residential mobility in North Kingstown may combine to form a townwide concern for planning and development in order to preserve the "old days" for long time residents and property values for the higher-ups. This is where their concern converges. Both towns have a firmly rooted stake and affection for their town, and have the drive, numbers, and resources to pursue their collective 
values. This affects the makeup and ability of the planning board and town council.

While there are many old-time residents in Middletown, their concern seems to be focused on the eastern half of town, which has never been seriously threatened by higher density residential and commercial development that characterizes the west because of large-lot zoning and lack of sewers. Middletown's primarily new or transient population may have something to do with the development pattern as well. New and transient residents may not have a firm political foothold from which to preserve values sympathetic to the land, and the fewer long-time residents may feel overwhelmed by a constant influx of different needs and interests. Lower home value and income may ultimately translate to lower tax base and less ability to hire planning staff and provide resources.

Miscellaneous

Both towns serve as a pass-through for tourists. North Kingstown is on the way to South County beaches and attracts many tourists to Wickford.

Middletown is on the way to Newport and has some beaches and other amenities, but is not a tourist destination per se.

Impending big-box commercial development is a political issue in both towns. Wal-Mart came into the quaint mill village of Lafayette in North Kingstown 
despite a prolonged hail of protest. The town ended up attaining a host of concessions from the developer including historically sensitive architectural details, excellent landscaping, and a mini-park with an amphitheater in the parking lot. Middletown is expecting a BJ's Wholesale Club on one of two sites in an already heavily developed section of town. This will add more impervious surface to the Bailey Brook watershed, but there is nothing really standing in the way except rezoning necessary for each site, which gives the town a bargaining tool.

Regarding transportation access, North Kingstown is more convenient to Providence and is therefore a more desirable bedroom community. Middletown serves Providence and Fall River, but bridges and lower capacity roads make commuting more burdensome.

\section{Landscape}

There is a dramatic difference between the landscapes of these two towns. Middletown's ideal soils and gentle terrain have left a dominant agricultural landscape, characterized by long views of fields and former fields only occasionally interrupted by small stands of trees and low vegetation. North Kingstown, while having had substantial agriculture in the past, has a much more dramatic landscape which makes farming more difficult. There are many more steep slopes and older trees than in Middletown, giving the towns very 
different visual characters. Both towns have many beautiful fieldstone walls along roadways, in open fields, and in woods that are a critical part of the cultural landscape. 


\section{Chapter Five: Development Project Profiles}

Note: Maps and photographs are in Appendix A

The purpose of the project review profiles is to explain the nature of each project including review history, physical characteristics and context, and reasons for either using a cluster design or not. I picked projects randomly from planning department files with the exception of Ocean Ridge, which I knew was a controversial project from a Middletown planning board meeting attended in July of 1996.

\section{Brookside at Quidnessett}

The first development proposed for this North Kingstown site was a subdivision called "Treasure Wood." It was proposed for one of the lots (a twenty acre piece) in 1987, but this project never got off the ground. Brookside began life in January of 1990 as "Seafields," a proposed seventeen-lot conventional subdivision. The site was composed of three lots equaling just under fifty-seven acres.

The site consisted of a two-family home and a cottage (one occupied by the landowner) and barn toward the front of the lot with a large gently sloping field behind it, leading towards a woody area with wetlands at the far southern end of the site. Trees surround most of the periphery of the site. Environmental constraints included approximately four acres of wetlands and some areas with a 
seasonally high water table. These areas were primarily towards the rear or southern end of the site, with some on the northeastern border as well. The brook, which forms the property boundary in one area, is a tributary to Allen Harbor. Because of the project's proximity to the brook and potential environmental effect on Allen harbor, project required review by RI Coastal Resources Management Council (CRMC). The presence of wetlands on the property required project review by RI Department of Environmental Management (DEM).

The landowner, Mr. Berube, presented a preapplication proposal with two conventional schemes. When asked why he only proposed conventional, he said that he felt that "the area was composed of large expensive homes ... and that cluster did not work as well with this site and the surrounding area." A discussion ensued about the "creativity allowances" possible through cluster zoning. The developer stated that he wanted his subdivision to resemble a nearby subdivision that has large lot zoning and large homes. He also stated that he felt that the cluster zoning category does not work well with large lots. The planning board expressed concern with traffic and the length of the cul-de-sac, which would be over 2,000 feet. Board member Mr. Vernon noted that the site had an "antiseptic look," but that he understood why the developer designed it that way. In this scheme, access would have to be provided by tearing down the barn at the front of the site. The development would require a variance for the 
entrance grade, which exceeded the three percent maximum. The board recommended that the developer proceed to the preliminary review stage. Instability apparently caused by the Rhode Island "banking crisis" that occurred in the early 1990's resulted in Mr. Berube losing the majority of the land. The parcels were then acquired from DEPCO and Mr. Berube by GMB Partners, LLC, who put together their own development proposal. The project resurfaced as a eighteen-lot cluster project called "Meadowcrest Estates" in November 1994. The applicant presented both a conventional yield plan and a cluster design, both based on a single long cul-de-sac. The primary developer, Mr. Baker, expressed that there was not much else that could be done with the design besides a long cul-de-sac due to the narrowness of the site. They proposed homes with two car garages and frontages ranging from 140 to 150 feet, trying to keep with the character of the neighborhood and the target market, averaging $\$ 400,000$ and up.

At the Conservation commission hearing, the drainage basins were explained, effect on wetlands was reviewed, and the project was recommended for approval. The Platting Board of Review granted a variance for the length of the cul de sac (2080 l.f.).

The cluster design allowed house placement away from wetlands and entirely out of the floodplain. It also provided almost twenty acres of open space preserved by an easement held by both the town and CRMC. The open space consisted of a seventy-five foot wide buffer along the periphery of the site, 
leading to a large area containing the brook and floodplain towards the rear.

The design failed to provide a vegetated buffer from the roadway, so the development still had substantial visual impact on the local area, which includes a proposed "agricultural historic district."

At the final approval hearing, several abutters were present to ask questions. One questioned the distance to the brook, and another was concerned about the size of the lots. The planning board explained that the cluster scheme placed houses as far as possible from the brook, and that the permanently preserved open space would offset the smaller lots and benefit neighbors as well as residents. The final plat was unanimously approved with fee in lieu of land dedication.

Houses at Brookside are in the $\$ 400,000-\$ 450,000$ range. It looks very much like a conventional subdivision because of sparse vegetation, acre lots, and large frontages. If the character the town wished to preserve was that of tract mansions, that has been achieved. They could have attained a more rural character by bringing the houses closer together towards the back of the site and restoring either the original barn or farmhouse as a dwelling. They might have even sacrificed two lots towards the road to give a wide open field effect. Unfortunately, the original farm structures were very deteriorated and the town didn't offer any incentives to design the site differently. 


\section{Quail Hollow}

Quail Hollow in North Kingstown was first proposed in November 1987. The 180 acre site consists of woodlands and nursery stock on dramatic rolling terrain. A stream runs through the site, and there are a substantial amount of wetlands, including a large wooded swamp. The site also lies within the Narrow River Aquifer, a protected area.

At the preapplication hearing, the developer Mr. David Cote presented several 63-68 lot conventional schemes that included twenty-four frontage lots. The development was proposed in phases. The commission didn't like the idea of so many frontage lots and requested fewer (perhaps shared) driveways and also wanted the developer to explore a cluster scheme. Apparently the discussion was rather heated, and Mr. Cote was resistant to the idea of clustering.

At the continued hearing a new conventional plan was presented. Mr. Cote presented a cluster design and it was "viewed from a marketing and phasing standpoint" (Minutes of North Kingstown Planning Commission meeting, 12/1/87). The developer stated his preference for conventional development. The Commission approved frontage lots and told the developer to proceed to the preliminary review stage for Phase I, which eventually received final approval. The commission could not force the developer to go with a cluster scheme and in essence gave conceptual approval for the entire subdivision as conventional, 
completed in phases as wetlands approval allowed. Phases two and three were approved and built conventionally.

One important issue that came up during phase two involved placement and maintenance of a large ( 1.5 acre) wet detention basin. The minutes state that the town will have responsibility of maintaining the basin because it "will become part of the overall drainage for the townwide system." The planner Mr. Peters thought that it should be located on town property, not on two private lots as proposed. The commission disagreed, stating that the town would not want the liability of owning the basin and so it should be located on private property. They said that it was "a marketing problem for the developer to worry about." The Commission eventually approved the plan as proposed, but began to discuss reviewing the remainder of the project as a whole before any more phases were allowed. Interestingly, there was no comment at all from the public during the hearing, suggesting no resistance. Ironically, at the same meeting the commission viewed the videos "Growing Smart" and Randall Arendt's slide presentation on cluster zoning by the Center for Rural Massachusetts.

In June of 1996, Mr. Cote submitted frontage lots for approval which were originally part of phase four. He proposed this because the remainder of the site has serious wetlands constraints. He received approval on the five frontage lots, and recently obtained approval for all of Phase IV. 


\section{Valley View}

A concept plan for Valley View was first presented in July of 1991, but the project really did not start until February of 1995 . The site is in central Middletown, surrounded by medium density residential with some roadside commercial to the east. All utilities are available to the site, but town water became an issue because an easement was required to connect to the high pressure line. There was a low pressure line easily available to the site, but this was insufficient because the site is on top of a hill. Until recently the land was used for agriculture, and consists of a gently sloping field leading down to the east branch of Bailey Brook. This brook serves as a major conduit for much of Aquidneck Island's water supply, so the site fell within Zone A of Middletown's watershed protection ordinance. Soils on the site are listed as highly erodable and potentially highly erodable according to the SCS Soil Survey.

At the preapplication conference, the developer's attorney presented a conventional plan with fifty-four lots and a cluster scheme with sixty-three lots, based on almost the same road pattern. The planner Mr. Silvia informed the developer that there was a mistake in their density calculation for the cluster, because there is no bonus for R-20 zoning even when utilities are available. This cluster plan has to use density based on a conventional yield plan. The result of the conference was that the board "moved to accept the cluster concept with changes to the road and cul-de-sac scheme, based on the 54-lot conventional subdivision plan." Mr. Silvia was not satisfied with the design, however, and 
commented to the board. First he asked what advantage was to be had to the town for going with the cluster if the similar road scheme doesn't reduce the amount of impervious surface. He also pointed that the amount and layout of the open space was almost the same as the conventional as well, except for the thin wetland buffer strip to the south. This would have been part of some people's back yards instead of one practically unusable continuous strip. While this does help protect the wetlands some, the cluster was not really designed specifically as a cluster; it is essentially a shrunken-lot conventional design with the road layout inherited from the conventional yield plan, which happened to have open space set aside. Middletown planning board Bill Stratford thinks it retained this design as a cluster because of the sensitive area constraints on the property. The developer had an engineered design that worked well for him, and the cluster made it that much easier to deal with the "riverbank wetland" area on the north and the small marshes and drainage issues on the south end. The developer, in fact, inherited a legal obligation to correct drainage problems on some adjoining property, and the plan they developed served all of the needs.

There also was controversy surrounding the actual allowable density because the developer included within the developable land area the hundred foot strip adjacent to the brook which was designated "riverbank wetland" according to a recently changed DEM regulation. The developer argued that it was only a buffer and could be counted, but the Town Planner Mr. Silvia held firmly and the board agreed with him, eventually disapproving the plan at the preliminary 
hearing for this reason. Ultimately the developer got the density he wanted. The Zoning Board of Appeals gave him a variance, and the developer effectively subverted DEM regulations. Mr. Silvia also found many other faults with the developer's submission that were eventually corrected, and the plan went for final approval in the summer of 1996 . In the period leading up to the final approval, the board and abutters raised a lot of concern over the open space configuration regarding use, maintenance, and plantings. Details regarding mowing, plantings, and fence placement were worked out but the cluster design remained basically the same, receiving final approval on July 10, 1996. Several abutters turned out at this meeting concerned with the disposition of the open space that would abut their property. Some were also concerned with erosion and impact to the brook and wetlands. Homes in this subdivision range in price from $\$ 137,900$ for a 1600 s.f. unit to $\$ 177,900$ for a 1825 s.f. unit with a two-stall garage. The houses come in a variety of classic-looking designs with substantial rich detail.

This seems to be a case where the developer had a lot invested already in the design and was unwilling to change it because of the investment in engineering. With R-20 zoning, there may not have been many more possible design configurations. The planning board doesn't know this, however, unless they require more than one cluster design. 


\section{Ocean Ridge}

Development of Ocean Ridge began as a single fifty-acre parcel of agricultural property known as Furtado Farm purchased by an investment group made up of physicians. The original proposal in December 1988 was for an assisted-care congregate living facility. This met with some resistance from abutting property owners. The developer withdrew the proposal and came back with another proposal for an eighty-four unit combined townhouse/single family cluster project, which again drew fire from the abutting property owners. The developer then fell into financial trouble and the parcel was acquired by West Meadow Partnership.

This developer proposed a conventional subdivision, and according to planning board chairman William Stratford, "they didn't want any part of a cluster subdivision." He feels that the developer was used to building "low to moderate income housing" on conventional lots, and had done two of these developments in neighboring Portsmouth. Many issues were brought up in the meetings leading up the final approval. Preliminary approval was given in January of 1993 after considerable debate over drainage issues and the need to extend a high-pressure town water line. The developer, Gerry. Warren, also agreed to conserve some open space, and there was concern from the board and Mr. Silvia over who would own and maintain it. Mr. Warren promised that he would work it out to the town's satisfaction. Another issue that arose in June of 1993 involved the developer illegally removing topsoil from the site. It lies 
within the jurisdiction of the Town's Erosion and Sedimentation Control Ordinance, so it was illegal for the developer to perform any excavation until he received final subdivision approval. In September of 1993, nine abutters came to the planning board meeting for Ocean Ridge with concerns about long-term island open space needs, traffic issues, housing types, dust issues, concern over wetlands, and drainage issues with a house built on adjoining property by the same developer.

The planning board gave final approval for Ocean Ridge in October 1993. Two planning board members, Heddy Bennett and Frank Mello, had to abstain during the whole process due to conflicts. Ms. Bennett stepped off because she owns property adjacent to the site, and Mr. Mello abstained apparently because one of his relatives also owns an adjacent parcel. Board member Dennis Klodner opposed the approval, probably because he was displeased with the open road leading to Morrison Ave.

According to the next day's Newport Daily News, Helga Lustig, an abutter in the Whitehall Farms development, raised concerns about open space. The planning board chair William Stratford was quoted as saying that "the developer already left fourteen acres as open space." This apparently is mostly unbuildable wetlands, with some upland lawns that will be maintained by a homeowner's association. The paper also noted that the board had to "twist the developer's arm to bring in water"(Newport Daily News: 10/14/93). 
The developer requested that the board allow the development to be done in two phases in April 1994. This request was granted, and the first phase was completed in a conventional manner.

Activity on the second phase began in July of 1996. Mr. Warren had since left the partnership, and Frank Boucher, a steel contractor, was left to finish the development. The conventional development was all approved, but for some reason $\mathrm{Mr}$. Boucher came in to the planning board with a detailed concept plan for a cluster design and a request for a zoning change recommendation from $\mathrm{R}$ 40 to $\mathrm{R}-30$. He needed the zone change because the Middletown zoning ordinance only allows cluster in R-10, R-20, and R-30 districts. The developer's proposed cluster plan retained the R-40 underlying density, and he stated that he was not looking for any more units than those he could build if cluster was allowed in R-40. The ordinance allows a $15 \%$ density bonus, so the number of units would increase from thirty-four to thirty-nine.

The cluster plan reduced the length of roadway from 4400 to 2900 feet. Catch basins would also be reduced from 32 to 19 . The cluster design would have provided approximately 22 acres of open space. The homes were going to be as nice as or nicer than the ones in the adjacent first phase. The developer's attorney explained the benefits of cluster (quite a thing to witness) and added comments about "the desire of people not to have one-acre lots" and how his client has difficulty marketing one-acre lots. 
The majority of the citizens present were residents of the first phase, built by the same developer. The developer's engineering consultant (Northeast Engineering) explained the layout of the development and open space, how the $\mathrm{R}-40$ density (plus bonus) would be retained, and all of the advantages of less impervious surface and less disturbed area. When the floor was opened for comments, there were major objections.

First, several people were angry because houses "on smaller lots" were going to be put adjacent to theirs, which were in an R-40 district. No amount of explanation by the consultant could convince them that the overall density (with a five unit bonus) would be retained as if it were still R-40, and that everyone would benefit from the open space. The developer even offered to sign an agreement to ensure that he would keep to the R-40 density, and that the only reason he was asking for the zone change was so he could use a cluster design.

There was also concern about Temic (an insecticide) contaminating nearby wells because the development site along with much of the surrounding area had been a potato field for many years. The were concerned that site disturbance would cause trapped Temic to be released down into the groundwater. The consultant explained very clearly that in the conventional development, all but 4.66 acres of land would be disturbed. In the cluster, much less of the area would be disturbed, providing even less of a chance for temic infiltration. But the people, one woman in particular, continued to object to any changes in the proposal. 
In the end, the planning board suggested that the developer withdraw his plan. During the whole hearing, the board members barely spoke. Two members, one of them an engineer, had to step off due to potential conflict of interest (Heddy Bennett and Eric Offenberg, who works for Northeast Engineers, the firm representing the developer). The only words of support came from one citizen, who said that the whole thing made perfect sense to him, and that the area needed to retain open space. Planning board Chairman William Stratford stated that the development has a long history of various proposals, culminating in a conventional plan that represents a lot of work from town officials and board members. He also talked about the people living in the first phase, who bought their houses with the understanding that the rest of the subdivision would be built as planned. He felt it would be unfair for the board to change everything now, and drag the development process out any longer. The developer's attorney said he "was getting the message" and that he would withdraw the request. 
Table 5.1 Project Information Matrix

\begin{tabular}{|c|c|c|c|c|}
\hline Item & Brookside (Cluster) & Quail Hollow & Ocean Ridge & Valley View (Cluster) \\
\hline Applicant & $\begin{array}{l}\text { GMB Realty Partners, } \\
\text { LLC }\end{array}$ & Quail Hollow Associates & West Meadow Partnership & Lawrence Leblanc, Builder \\
\hline Site Size & 45 acres & 180 acres & 50 acres & 43 acres \\
\hline Existing land use & Three unit dwelling & $\begin{array}{l}\text { Nursery stock and } \\
\text { undeveloped woodlands }\end{array}$ & Agriculture/crops & Active agriculture \\
\hline Zoning & Rural Residential & Rural Residential & $\mathrm{R}-40$ & $\mathrm{R}-20$ \\
\hline Comp. plan designation & Low Density Residential & Low Density Residential & Low Density Residential & Med. Density Residential \\
\hline Density/ \# Lots & $\begin{array}{l}17 \text { proposed; } 18 \text { cluster } \\
\text { would fit, } 22 \text { conventional }\end{array}$ & 68 lots & 46 lots & 56 lots \\
\hline Location & $\begin{array}{l}\text { Fletcher Rd, NK; AP 163, } \\
\text { Lots } 1,5\end{array}$ & $\begin{array}{l}\text { Shermantown and } \\
\text { Congdon Hill Roads, NK; } \\
\text { AP 35, lots } 8 \text { and part of } 5\end{array}$ & Paradise and Prospect Aves. & $\begin{array}{l}\text { Off Valley Rd. north of } \\
\text { Longmeadow Ave. }\end{array}$ \\
\hline Topography & $\begin{array}{l}\text { Gen. level with gentle } \\
\text { slope to south towards } \\
\text { brook }\end{array}$ & $\begin{array}{l}\text { Gently rolling with some } \\
\text { severe slopes }\end{array}$ & $\begin{array}{l}\text { Gently rolling with some } \\
\text { slopes }\end{array}$ & $\begin{array}{l}\text { Gently rolling with some } \\
\text { slopes up to } 15 \%\end{array}$ \\
\hline Soils & $\begin{array}{l}35 \text { acres have no } \\
\text { development limitations }\end{array}$ & $\begin{array}{l}1 / 2 \text { of the site has } \\
\text { seasonal high water table, } \\
1 / 4 \text { has slow } \\
\text { permeability. Erosion } \\
\text { potential. }\end{array}$ & $\begin{array}{l}\text { Severe septic constraints. } \\
\text { High erosion potential. }\end{array}$ & $\begin{array}{l}\text { Silty loam w' high erosion } \\
\text { potential, slopes towards } \\
\text { Bailey Brook }\end{array}$ \\
\hline Amount of wetlands & $\begin{array}{l}\text { Along west and east } \\
\text { boundaries, but most on } \\
\text { south boundary. }\end{array}$ & $\begin{array}{l}\text { Large wooded swamp in } \\
\text { northern part of site } \\
\text { (Phase IV) }\end{array}$ & $\begin{array}{l}\text { Small "cow ponds" } \\
\text { scattered throughout site }\end{array}$ & $\begin{array}{l}\text { "Riverbank wetland" area } \\
\text { in north of site }\end{array}$ \\
\hline Historic/cultural elements & $\begin{array}{l}\text { Old farmhouse } \\
\text { (Demolished) }\end{array}$ & $\begin{array}{l}\text { Old farmhouse } \\
\text { (Demolished) }\end{array}$ & None & Stone walls \\
\hline Utilities & Water & Water & Water and sewer & Water and sewer \\
\hline Drainage structure reqd? & $\begin{array}{l}\text { Yes, closed system with } \\
\text { detention ponds }\end{array}$ & $\begin{array}{l}\text { Yes, closed system with } \\
\text { detention ponds }\end{array}$ & $\begin{array}{l}\text { Yes, closed system with } \\
\text { detention ponds }\end{array}$ & $\begin{array}{l}\text { Yes, closed system with } \\
\text { detention ponds }\end{array}$ \\
\hline Floodplain & $\begin{array}{l}\text { Yes, in southwestern part } \\
\text { of site }\end{array}$ & No & No & $\begin{array}{l}\text { Yes, some on northern part } \\
\text { of site }\end{array}$ \\
\hline
\end{tabular}


Project Information Matrix,

Cont.

\begin{tabular}{|c|c|c|c|c|}
\hline Item & Brookside (Cluster) & Quail Hollow & Ocean Ridge & Valley View (Cluster) \\
\hline General site conditions & $\begin{array}{l}\text { Majority large open field, } \\
\text { with trees along } \\
\text { boundaries and around } \\
\text { wetland areas }\end{array}$ & $\begin{array}{l}\text { Dramatic terrain, lots of } \\
\text { steep slopes and trees }\end{array}$ & $\begin{array}{l}\text { Large open field, former } \\
\text { potato farm }\end{array}$ & Large open field \\
\hline $\begin{array}{l}\text { Adjoined neighboring } \\
\text { open space. }\end{array}$ & $\begin{array}{l}\text { Yes, not permanently } \\
\text { protected }\end{array}$ & $\begin{array}{l}\text { Yes, not permanently } \\
\text { protected }\end{array}$ & $\begin{array}{l}\text { Yes, cropland, hayfield, and } \\
\text { land bordering wetlands }\end{array}$ & No \\
\hline $\begin{array}{l}\text { Adjoins other } \\
\text { developments? Size, } \\
\text { character? }\end{array}$ & $\begin{array}{l}\text { Yes, low density } \\
\text { residential }\end{array}$ & $\begin{array}{l}\text { Yes, Neighborhood } \\
\text { residential }\end{array}$ & $\begin{array}{l}\text { Yes, similar density } \\
\text { residential }\end{array}$ & $\begin{array}{l}\text { Yes, similar density } \\
\text { residential, }\end{array}$ \\
\hline $\begin{array}{l}\text { Next to active farmland- } \\
\text { buffer issues }\end{array}$ & No & No & Yes & $\begin{array}{l}\text { No, was the last active } \\
\text { farmland in the } \\
\text { neighborhood }\end{array}$ \\
\hline $\begin{array}{l}\text { In any type of priority } \\
\text { protection area, protected } \\
\text { or not? }\end{array}$ & No & No & $\begin{array}{l}\text { Within wellhead protection } \\
\text { district }\end{array}$ & $\begin{array}{l}\text { Yes, watershed protection } \\
\text { zone } 1 \text {. Within wellhead } \\
\text { protection district. }\end{array}$ \\
\hline $\begin{array}{l}\text { Historic element } \\
\text { protection, stone wall or } \\
\text { scenic view ordinance? }\end{array}$ & No & No & No & No \\
\hline Surrounding zoning & Rural Res, RR Cluster & $\begin{array}{l}\text { Rural and Neighborhood } \\
\text { Residential }\end{array}$ & R-40, R-20, R-30 & R-20, LB, GB \\
\hline Surrounding land use & $\begin{array}{l}\text { Single family, } \\
\text { agricultural, undeveloped }\end{array}$ & Residential & $\begin{array}{l}\text { Residential, commercial to } \\
\text { the east, intensive farming to } \\
\text { the west. }\end{array}$ & $\begin{array}{l}\text { Dense residential, } \\
\text { commercial to the north. }\end{array}$ \\
\hline $\begin{array}{l}\text { Previous development } \\
\text { proposals that would effect } \\
\text { attitude towards site }\end{array}$ & $\begin{array}{l}\text { Yes, conventional } \\
\text { subdivision proposed }\end{array}$ & No & Yes & No \\
\hline
\end{tabular}




\section{CHAPTER SIX: INTERVIEW RESULTS}

In order to assess perceptions about cluster, I interviewed four developers (one for each of the case studies, three planners, and three planning board chairs).

\section{Developer's Views}

The first developer I interviewed was Larry LeBlanc, who developed "Valley View" in Middletown. He is one of the largest and most successful builders in Rhode Island, and had plenty to say about cluster development. One of the shortcomings he and other developers mentioned was that drainage is sometimes more difficult to design and maintain in a cluster. There is also conflict and confusion sometimes between what the planning board or staff wants to see and what other town departments require. Road standards are a typical example of this, where what seems to be good functional or aesthetic design to the planners conflicts with public works or the fire department (LeBlanc 1997).

Another situation that results in uncreative and therefore unsightly and less marketable developments is when inexperienced developers let their engineers design their development all by themselves, as they tend to be "driven by geometry" (LeBlanc 1997). Good planning input regarding aesthetics and ecological values is necessary to avoid a purely functional rigid subdivision. One seemingly small but important advantage to open space buffers is because "sometimes surveyors make mistakes and they tend not to be bonded." The open space serves 
as a legal buffer as well, so homeowners don't feel shortchanged if the property line is a few feet off.

LeBlanc indicated that in his experience, most planning boards would rather see cluster primarily because of the preserved open space and the reduced amount of street that the town has to maintain. All boards are different, however. Some are very political and all have varying levels of expertise. Some towns have a strong planner who influences the board, others have a very strong board member or town solicitor with great influence. LeBlanc feels that boards don't always understand all of cluster's potential benefits and applications. This really depends on the individuals on the board.

On the balance according to Mr. LeBlanc, cluster is definitely more positive than negative not only because of environmental and aesthetic values that are enjoyed by everyone, but also because of higher resale value. In his experience clusters or "mini-PUD's" are the best method to develop because of both flexibility in design and the control afforded by the homeowner's association. He says flexibility in design allows the developer to place houses on good soils as well as provide open space buffers, both of which create a higher quality development. The homeowner's association provides an official mechanism for common property maintenance and an either formal or informal mechanism to ensure maintenance of individual's properties in order to maintain neighboring property values. LeBlanc feels that covenants for maintenance and other issues are a good idea not just for clusters, but for all developments. 
"Brookside" developer Mike Baker emphasized that one of the primary benefits of cluster to all parties involved is the ability to build away from wetlands. From the developer's standpoint it makes permitting much easier because larger buffers are created. Large buffers make both DEM and the local Conservation Commission happy. He stated that "In every project we've done we've been able to stay away from formal wetlands applications because we've had more flexibility by using a cluster, whereas if we did traditional and I was forced to max out and get the lots I needed to make it work by going through wetlands, I would have been forced to do it." Easier permitting saves both time and consulting costs, and since time is money in the development business, there is a dual economic benefit. It is "a two way street" because the public also benefits from having its wetlands better protected, and from the additional wildlife habitat provided by the open space.

The last three or four developments Baker has done in North Kingstown have been clusters, and he definitely thinks that the benefits outweigh the costs "in most cases." Most properties for development he has seen have some types of restrictions that cluster helps accommodate.

Among the shortcomings of cluster, Baker notes that like their conventional counterparts, clusters tend to be "over-engineered." By this he means that road widths are sometimes excessive and drainage requirements are too elaborate and inflexible in many cases. The primary shortcoming he sees is inflexibility of regulations. He termed it as a "bureaucratic mentality that this is what the regulations say and whether it makes sense or not that's what we've got to do." He 
recalled the example of Brookside where "for years there was no discussion or no desire to put in sidewalks, especially in dead-end culls-de sac, and all of a sudden someone decided we want sidewalks." All of a sudden it was a big issue, and to Mr. Baker it seemed to come out of nowhere. He doesn't know of any cases in a situation like Brookside where lack of sidewalks have ever been a problem. Even in the more traditional neighborhood in which he lives, where it is much denser and the town beach is nearby, people don't use the existing sidewalks. Children play in the street and adults wander down the middle of the road to the beach.

Another example of a regulation that is perhaps unnecessary in some situations is the requirement to submit multiple cluster schemes in the preapplication stage. If the "developer really knows what he wants to do, and it meets the requirements, I'm not sure why the board [should say] we'd rather just for aesthetic reasons or personal preference... see this plan than that plan; I think that kind of issue is really up to the developer." While this may raise planner's ire, an experienced developer with good design sense might in some cases be better qualified to make that decision than a citizen board. This may actually be a barrier, where the developer is afraid to put a lot of resources into designing something the board is just going to redesign anyway. 


\section{Marketability}

Regarding cluster's marketability, Mr. LeBlanc thinks it is good, but it requires the developer or real estate agent to educate the consumer and point out benefits. He indicated that it was easier to sell as it got older because the site vegetation matures and the whole development is maintained. It could also become more valuable with age because neighboring areas are developed and all unprotected open space disappears.

Dave Cote felt that cluster housing seems to be "accepted very well" and pointed out that in one North Kingstown cluster, Wickford Highlands, over one hundred thirty lots were easily sold within three years. This is substantiated by North Kingstown planner Lee Whitaker, who adds that all North Kingstown clusters are filling up quickly.

Larry LeBlanc thinks there is some sales resistance because "people don't want to buy into a commune" (regarding homeowner's association obligations). The enforcement aspect of the HOA is a turn-off to some people, and others simply want absolute personal control of the land. They are literally seeking "the American dream," and this does not include shared ownership of land or a "shadow government" to take care of it. Mike Baker sees this as "an issue," but not as a barrier. He thinks that buyers are "much more sophisticated now and most buyers are going to know and understand it before they make their decision." One must take into account that Mr. Baker does sell at the high end of the market, however. 
"Quail Hollow" developer Dave Cote pointed out that while cluster is undoubtedly a good concept, it "just doesn't work everywhere." Some boards want to see conventional developments for whatever reason, it seems. One potential reason for this pointed out by LeBlanc is past bad experiences by board members with cluster. Inadequate regulations can be the cause of this, and the town may be unwilling to change the regulations because they fear it might stimulate development. No change seems safer than meddling and perhaps making things worse. Mr. Cote also noted that there will probably always be a market for conventional developments just because of people's preferences. They "love their two acres" even though they may not use it all. In this case the development "still has open space, it's just in people's own yards" (Cote 1997).

Mike Baker thinks that cluster "seems to have worked in North Kingstown." $\mathrm{He}$ sees frontage width as a major factor in marketability, where wider frontages are easier to sell because people really value their breathing space and privacy. $\mathrm{He}$ brought up Wickford Point (an upscale neo-traditional development in North Kingstown) as an example, saying that "I think ultimately they'll get there and fill the thing up but to me it's a real gamble and you would have to have a lot of money and a lot of patience to develop a piece of property that way. Down there I think the same thing's happened though, their prime land really isn't as clustered, it's more in line with what I'm talking about here where the lots on the end are fairly good size and have some privacy, have some separation, whereas going in to the property the first seventy or eighty lots are real tight and the marketability of a sixty-five foot 
frontage lot; I wouldn't want to be in that situation." He sees lot size as very important as well, and feels that once you get into the one-acre range where people begin to get that "envelope," it doesn't matter if the space in back of them is owned by the homeowner's association or not.

He thinks "there's a misconception out there in places where it [cluster] is not encouraged or understood that somehow the developer is getting more density or more units in a cluster where really, at least in North Kingstown, it's not the case. It's not any easier, the only benefit financially is the length of the roads, and to me that's a tradeoff on the value of the lots because I think a two-hundred foot frontage lot is more valuable than a one-hundred foot frontage lot." He was surprised to find out that Middletown has a density bonus, and wasn't sure how much that would mean to him.

He stated that he "knows that there's the perception, when you start hearing towns talk about it, you know Exeter just hasn't done anything with cluster either and they have this fear that it's going to destroy their rural character; I don't think it needs to if they do it right, and I don't think there necessarily needs to be a bonus for the developer in the number of lots you get; I don't think you should be penalized either..." 
"The Path of Least Resistance"

Both developers Dave Cote and Larry LeBlanc expressed that the biggest factor in acceptance of any development is the planning board's attitude. The importance of this can not be overstated. Simply put, any good developer quickly realizes that time is money, and they can't afford unnecessary delays. Developers can be creative within limits, but the true trick is to "find the point of least resistance." Resistance in any form is potentially dangerous. Developers should know that the "preferred process will be accelerated." Planners and boards typically let the developer know what their preferences are, and have the means to enforce their will. LeBlanc expressed that in this way "good planning works." By this I believe he means that planners and boards have to be proactive and let their preferences be known right up front. The developer can not afford to guess and keep coming back. Many developers will even give up acreage to attain quick approval (LeBlanc 1997). Both Dave Cote and Mike Baker think that the North Kingstown planning board does advocate cluster and that they definitely understand the concept and applications.

\section{"Pesky Geometry"}

One definite disadvantage to cluster pointed out by Dave Cote is that by reducing the lot size, the size of the house footprint is also reduced. Depending on setbacks and floorplans, one can start to have problems when the house goes over 
approximately 2,800 square feet. This house size may sound huge, but with twoacre minimum zoning in some towns it only pays for the developer to put up houses in this class. Between regulations and property taxes, towns are effectively "regulating rich neighborhoods" (Cote, 1997). By this he means that developers are unable to build houses in the lower end of the market because zoning requires such large lot sizes.

When asked if there were any conditions under which cluster would be less marketable, Mike Baker responded that "probably in a situation without a lot of development restrictions, where [conventional] worked well, where you had a large enough piece that was not oddly shaped that you could fit those larger pieces in to... up to a two-acre subdivision I can see it making sense on some pieces, but when you get into four-acre or five-acre zoning I think, depending on what you are trying to create I would lean towards keeping [lot sizes] two acres and keeping the rest common land in a cluster." In talking about towns that don't have the cluster option, he said "I get less excited about a large piece of property when I know I have to do a traditional."

Open Space

Commonly held open space could potentially be a barrier to using cluster because of perceived effects it has on marketability and perhaps because of the unwillingness of the board to create a potentially burdensome legacy. The buyer would have 
concerns about liability, taxes, and maintenance (these are "red flags" in Mike Baker's terms). Mr. Baker doesn't think the costs outweigh the benefits, though. He says that "once people find out that they can get an insurance policy for their association [they realize that] they can be protected on those issues." The maintenance, he feels, depends on the particular property and what the residents want to do. He doesn't see the HOA as an active force; they simply do what is necessary for reasonable upkeep for minimum cost. This seemed to be echoed by North Kingstown planner Lee Whitaker, who lives in a cluster. He says the fee is reasonable and that it accounts for necessary insurance and maintenance.

\section{Abutter Acceptance}

The developers did not see any problem with abutters, and in their experience abutters prefer cluster because of natural buffer areas. The only problems they could see is possible concern about reduced lot sizes and just a general misunderstanding of the cluster concept by the public. Ignorance seems to be the biggest problem, so in the end it becomes an education process. 


\section{Planners' and Board Members' Views}

\section{North Kingstown Planning Views}

To assess views of cluster in North Kingstown from the planners' point of view, I interviewed two planners and the present and immediate past planning board chairs. Planner Lee Whitaker has been planning since 1973. He has worked for various divisions of the Rhode Island Department of Environmental Management, and also in a private consulting firm for seven years. He has been with North Kingstown for three years, but did subdivision review for the town while in the private sector. He seems to wholeheartedly support cluster, and described many substantial benefits. He feels that cluster can help produce a "more livable community" for both residents and the town as a whole.

When asked whether he thought the present regulations could stand any improvement, he noted that they had recently drafted changes in the zoning ordinance and subdivision regulations to make them consistent with the comprehensive plan. He said that there is also talk of going to three or five acre zoning in some areas, but they would have to see how the present cluster regulations would work with those lot sizes. The planning department is also looking at Randall Arendt's work and the Newport Collaborative's Rural Design Manual. They are presently considering flexibility in certain regulations, leaning more towards performance and design standards to avoid some of the less fortunate results gained from strict standards. Mr. Whitaker gave one example based on the 
present regulations where a cul-de sac can be designed so that one house's backyard looks straight into the side of another. He thinks flexible standards can help avoid this kind of result.

Whitaker said that from his experience local developers tend to know what's going on in a particular community and follow the trends, and it takes a little time for innovations to catch on. Developer Larry LeBlanc stated the same thing but from the other side: that "there are trends in planning" and the developer has to follow them once they are established. One of the most important elements, it seems, is for a planning department and board to establish a good trend in the direction that they want to go (North Kingstown has done this). This sounds trite, but perhaps it is worth exploring what makes and breaks trends.

Whitaker thinks the major shortcoming of cluster is acceptance in the marketplace, but as time has gone by there seems to be much more willingness to accept cluster subdivisions. "Developers seem to feel there's a clear benefit to them by not having to pay for all of the infrastructure that would normally be associated with a conventional subdivision." He also thinks the prospective buyers are realizing the benefits of the open space, and that more developers are taking advantage of it by creating foot trails and other amenities.

Whitaker feels that cluster does make it easier to develop some parcels because it allows developers to handle wetlands and archeological issues better. Overall density is calculated through a yield plan taking placement of houses and septic systems and proximity of wetlands into account, but cluster provides the 
opportunity to design higher quality houselots with more usable land. It also makes DEM Wetlands Division and CRMC review easier because buffer zones can be expanded. This is very valuable to the developer because these reviews can take a substantial amount of valuable time. He says "it gets increasingly difficult to justify a standard, conventional subdivision for any reason other than that's the market you want to go for."

North Kingstown Planning Director Marilyn Cohen has been involved in planning for approximately seventeen years, and has worked for the town for the last ten. She thinks the main disincentives to cluster are responsibilities associated with the Home Owner's Association and that sometimes lots are a bit too small and either limit or don't match house size. Present North Kingstown planning commission chair Mike Desmond agreed with Ms. Cohen that one shortcoming is that the lots are sometimes too small for the houses that are built on them: "these humongous houses on these little lots; if you drive through there it looks kind of funny."

In one case, for example, a developer wanted to farm the undeveloped land in a proposed cluster, but didn't want the land to be held by a homeowner's association. Ms. Cohen thinks there should be a mechanism for something like this if the result is consistent with community goals. For instance, a negative easement could be put on the land removing the development rights, but the farmer could own the land and be responsible for it. The state Enabling Act currently does not allow this, but Ms. Cohen thinks something might be worked out using transferred development rights. 
The town's strategy to preserve open space involves acquisition of development rights.

Ms. Cohen attributes North Kingstown's early adoption of cluster to the fact that the town had progressive planners working in the office who provided information to council and commission members and citizens. Like most of the other interviewees, Ms. Cohen felt that abutters don't like any development and they object to the reduced lot sizes in the cluster because of their lesser value. They will explore the "flexible zoning" concept as presented by the Newport Collaborative's work sometime in July 1997. She thinks the planning department will have to test the concept by designing a few sites in-house to make sure it works well. Flexible zoning will help designers configure the open space more creatively than the existing ordinance, which according to Ms. Cohen, sometimes produces conventional-looking subdivisions with the houses closer together.

When asked if she thought requiring a special permit for cluster would be an unnecessary hurdle, Ms. Cohen agreed. She said that the only provisions in their regulations that might inhibit clustering is that some developers sometimes think they may lose lots by going with cluster because of the way soil constraints are calculated in the North Kingstown cluster regulationsii. Ms. Cohen feels that it is not the case, especially in areas that are reliant on septic systems. She added that she thinks developers feel burdened by having to prepare a conventional scheme to demonstrate how many lots they can get. 
Ms. Cohen thinks there are enough incentives to do cluster but that developers may have a different opinion. Surprisingly, the developers did say that there are enough incentives. The planning department has looked into density bonuses, but they found that the ability to better deal with environmental constraints is enough incentive to cluster. On the issue of sidewalks, Ms. Cohen mentioned that both the planning commission and the school department favor them.

When asked why Quail Hollow went conventional, Ms. Cohen said that the developer is well respected in the community and knows what his market is. She expressed that Mr. Cote probably would have had much less of a problem getting wetlands permits and gotten the same number of lots if he had gone with a cluster design. She recalls a fairly heated preapplication meeting where the commission tried to convince the developer to do cluster, but he did not want to.

Jim Dobson was the North Kingstown planning commission chairman for ten years. He sees cluster as a way to create a better environment for the cluster neighborhood itself as well as a way to give the developer an opportunity to be innovative. He also sees benefits for the overall environment such as less impervious surface and lawns.

Regarding innovation, he said, "If a town doesn't provide them [the developer] with innovative opportunities, it isn't that they haven't thought about it, it's that they get frightened by it. A developer isn't going to go into a community for example, that may not have some innovative thinking and [the developer] is not going to present a proposal that's innovative for fear of being shot down... for fear of 
being radical in their proposal, so they're going to come in with whatever the community is going to construe to be acceptable." This agrees completely with what Larry LeBlanc and Dave Cote said about "the path of least resistance."

He emphasized that a development does not necessarily have to be a cluster to be innovative. He sees some cases (such as a reclaimed gravel pit) where cluster might not make sense because there are no constraints, significant vegetation, or valuable natural areas. In these cases he sees an opportunity to do something that isn't either a cluster or a conventional but uses any number of design innovations to create something unique. He sees the board's role as encouraging innovative thinking on the development team's part with the promise that "we're not going to whack you on this." He thinks it's very important that towns remember that the third option exists.

He sees his role (at its best, I think) as "working with these people [developers], not in opposition, but together to try and create an environment." He sees it as "providing them an opportunity to understand what's beneficial to them," and feels that the architects and engineers working for the developer understand creative solutions. He also advocates simple solutions, such as tagging and keeping track of trees to ensure they aren't cut if they enhance the site environmentally. He also feels that the whole board understands design issues and the importance of providing innovation opportunities. 
Regarding marketability, he has gathered from the input he's received over the years that clusters tend to be more marketable in the lower-range price categories (quarter-million and under).

Mr. Dobson attributes cluster's success in North Kingstown to "coming out of the box faster," through the work of enlightened planning commission chair, John Kupa. Curiously enough, Dr. Kupa was a professor in the University of Rhode Island's graduate planning program. He and Aristis Monteresy, who also has a planning background, initiated the cluster ordinance (perhaps they were instrumental in revising the zoning ordinance in 1980). He said that "because we had some successes early, we saw the ramifications of the cluster ordinance, and in 1985 or $86 \ldots$ we saw the open space we were able to garnish as a result of the cluster ordinance as well, [so] why wouldn't you want to pursue it." "Not to mention the terrain, and that's once again critical; we have terrain in this community that obviously lends itself to clusters." Mike Desmond noted that "it [cluster] was the prevailing thinking when I came aboard."

Mr. Dobson does think the cluster ordinance should not penalize the developer through the way restrictive soils are discounted, but he doesn't see the present method as a hindrance. Developers are required to bring both cluster and conventional plans to the preapplication conference, and it becomes an issue of what is appropriate for the particular site. If the commission feels that cluster is appropriate in that situation (as it almost always has), that's the design they are going to push for. Considering the developer's comments above, if they know what 
is good for them they will do what the board says. Mike Desmond thinks that there are definitely enough incentives to do cluster, and says this because "they typically come in wanting to do the cluster." Both the planning commission and staff know which plan the developer prefers because it is usually the only plan that has been rendered (colored).

Mr. Desmond isn't sure that the town really needs to change the regulations per se to get what the town wants. He seems to think that the town has and will continue to have success encouraging developers to come in with innovative plans and then "working with them," rather than trying to force them to do something. He contrasted the need for rules to restrain unscrupulous developers with the need for flexibility. This view supports the idea that Arendt advocates of having the strict conventional regulations (perhaps even with disincentives), with the option of creative conservation design incorporating general performance requirements with maximum flexibility (Arendt 1994; 21).

\section{Middletown Planning Views}

Charlie Silvia has been involved in planning for ten years as the Middletown Town Planner. He has no formal planning degree, but was involved in plans and operations while in the US Navy, where he was also a pilot.

He sees the greatest benefit, or at least the first one he thought of, as the reduction of the cost of house lots. He also mentioned reduction of impervious surface and noted that it can create a more attractive subdivision. 
He sees the main shortcoming as "that developers oftentimes use it as a method of squeezing in houses that perhaps they couldn't squeeze in otherwise." This is both through the density bonus and through different utilization of land. Even though there is a yield plan, Charlie gets the impression that the developer is somehow gaining more than is fair. An example of this might be that while particular lots near wetlands or with severe slopes may be legal dimensionally, they may not be usable, problem-free lots. What may pass by the planning board on paper may not get through DEM on the ground, at least not without difficulty. He also mentioned that you end up with smaller lots, which may or may not be a shortcoming, depending on your point of view.

He then indicated that "maybe it's just been our experience that we haven't been too good at making a cluster really look like a cluster. We tend to sometimes bunch the houses on one portion of the site, and have the open space removed from a good many of the houses. That's a shortcoming we've tried to improve over time by making our rules more specific on how the open space should be."

He thinks it's just as marketable as a conventional subdivision because from his experience of late a good many people don't care to have as large lots. "They get the house they want, except they don't get as large a yard. But, with the proper open space, they get the feeling of having the same size yard without actually owning that portion; again, depending on the subdivision layout."

He believes that the town has accepted clusters, but "sometimes, maybe, when looking at it, we may create some factors that discourage the developer from doing 
it, but I think for the most part, when people come in for cluster subdivisions they have been getting them. I don't think we've encouraged or discouraged them."

One of the factors Charlie sees as potentially discouraging for developers is that when all is said and done, sometimes the road system doesn't change much between the two types of development, so the infrastructure savings are not there, and the developer says "why don't I just do a conventional." Valley View is a good example of this.

He sees no negative bias against cluster by board members, but he doesn't think they advocate it either. When asked why, he said that "as much as anything else past experience with some cluster developments that haven't worked out the way they anticipated and it's gotten to the point that they would just as soon see a conventional subdivision. It's past experience." He cited problems in the past with "oftentimes you can't get an appreciation for the open space and how it works with the subdivision." He believes that the board understands the potential benefits and applications of cluster and this is why they got rid of the density bonuses "because it was too beneficial to the developer and not beneficial to the town."

Under the older regulations, they used to encourage developers to do clusters because they got a density bonus. Cluster used to be an option in all districts ( $R-60$ being the largest), with a $25 \%$ bonus for parcels in R-30 or above with sewer and water, $20 \%$ with either water or sewer, and $15 \%$ in neither. The new ordinance (changed 11/89) allows cluster only in R-10, R-20, and R-30 zones, with a 15\% density bonus only in R-30 if it has both sewer and water. Mr. Silvia is generally 
supportive of the regulations how they stand right now, but he would recommend they get rid of all density bonuses and allow cluster in R-40 and R-60. When asked if he thought he would see resistance to the changes, he said no. I then asked if it just hasn't been a priority item because of the type of development coming in, and he agreed. I asked if there were any initiatives now to change the regulations, and he said that "next time we have a zoning ordinance change we will have changes to the cluster ordinance. I think we'll see a little more flexibility." Some elements of flexibility he named were "to think about the requirement for underground utilities" and the 26 foot roadway width. A primary concern would be (especially in the east) to use flexibility to preserve farmland. He placed emphasis on the importance of making the saved farmland contiguous to make it easier (even just worth it) to farm. He says that his board seems to be "Hard and fast on road width." Regulations require the same size road in both conventional and cluster. He doesn't think the board wants to reduce it, but they "have never really sat down and discussed the issue."

Properties without municipal sewer and water are pretty much disqualified for cluster because of anticipated septic system problems and well conflicts, but they only very seldom approve any subdivision of any size without these utilities.

"In many cases [cluster] is received pretty well [by abutters] because they find that they have larger buffers between them and the next subdivision." When asked if he thought they would rather see a conventional go in, he said that he really couldn't say, but implied that they really don't want anything going in next to them. 
Mr. Silvia brought up the fact that the lay of the land in Middletown, which is typically wide open fields, often doesn't support cluster because there is no mature vegetation to help hide houses. Middletown's topography and vegetation make it very easy to "take a wide-open lot, cut it up, put streets in, and be done with it; of course, it doesn't make as attractive a subdivision. Some of the clusters over the other side are pretty darn good because they are able to [use the land to an advantage]"(Silvia 1997).

He said that he "almost gets the feeling that the developer feels that it's less complicated and cumbersome do a conventional rather than a cluster subdivision, therefore they opt for an easy way out." I asked if it was because of less time in front of the board and not having to worry about open space and he agreed. He added that it was less homeowner covenants as well, and that the developer would "just as soon get the land, cut it up, sell it, and be done with it."

He doesn't think the developer has to make the case for cluster per se. If they come in and meet the criteria, they can go ahead and do it. He doesn't think there are any barriers, except perhaps in the developer's understanding of what he has to go through.

Mr. Silvia named "a feeling of openness" and water quality advantages as the benefits of shared/preserved open space. He sees smaller lots as a disadvantage, sometimes making the house appear too big for the lot and too close together. 
William Stratford has been on the Middletown planning board for seventeen years, nine of them as chairman. He has no formal planning background, and practices what he terms "common sense planning." He works as a marine contractor and has been involved in construction for forty-three years. He was born and raised in Middletown, and feels he knows the needs of the town very well. He applied to the planning board in response to the real estate boom when "developers were starting to rape the environment and the town." He says he felt strongly about "protecting open spaces and sensitive areas."

He feels that as chairman he potentially has great influence on the policy of the board and the direction it goes on particular issues. He says he tries not to influence the board in this way, and tries to solicit everyone's input. Very rarely do they get a vote that is not unanimous.

He says that "different people have different concepts of cluster development, and unfortunately the rules and regulations of cluster development [presumably Middletown's] don't define a cluster exactly how we would really like to see a cluster." Mr. Stratford related that they have two or three supposed cluster subdivisions in town that he "doesn't believe are true cluster subdivisions." He feels that they have a very good example of a cluster, the Whitehall townhouse development. He believes this is a good example because the units are truly clustered together and approximately seventy percent of the land was preserved as open space. He noted how this example really reduced the amount of impervious surface, and how it "is the type of cluster I envision and would like to see take 
place." He doesn't favor townhouses per se, and said single family home clusters are fine "if you can dedicate the open space equally among the subdivision so all of the people have benefits... and it gives a little more openness to the development." He named the example of "Windham Hills," where the houses are on 20,000 s.f. lots in R-60 zoning. There are fourteen acres of open space on the far eastern side of the property managed by the home owner's association and used for agriculture. The problem he sees is that the residents of the subdivision don't get the true benefit of the open space that they expected they were going to get from the cluster. He thinks it would benefit the residents more if the open space was "dedicated in smaller areas throughout the subdivision."

The first benefit of cluster he named was water quality due to the reduced impervious surface. He also said that it adds aesthetically and has a positive effect on property values. In addition, he feels that in a cluster "people have a tendency to be more in tune with keeping their yards and their grounds more pristine and manicured."

As for shortcomings, he sees nothing serious from a planning perspective. One potential shortcoming he sees from a homeowner's standpoint is that "once you sign on the dotted line and become a member of a home owner's association... you're bound by a set of rules and regulations that you have to live by that's not incorporated in living in a conventional subdivision where you own your property and there's no home owner's association to deal with." He also mentioned that on 
top of having two sets of rules (the HOA's and the town's), the assessed fee is another thing to deal with.

He noted that most of the land left in Middletown is in R-40 and R-60 zoning, so he can see "as the town grows, some of the forty and sixty thousand zones being reduced as soon as the sewer and water is extended out." He sees this "as a good opportunity for us to have a good cluster ordinance in place so we can control the sprawl of conventional subdivision." He thinks that the town council will definitely reduce the lot size when utilities are extended, based on past council statements and concern from the public that sixty-thousand s.f. lots were too big and "who the hell wants to cut grass on a sixty-thousand square foot lot." The past council president's feeling was that they were using the large lots "to keep the control of the subdivisions going into areas that aren't serviced by sewer and water." He feels that sewer extension to the east and lot size reduction is "a given."

When asked if his board advocates cluster, Mr. Stratford responded "very much so." He also thinks that the board definitely understands all of the potential benefits and applications of cluster.

He feels cluster is received very well by abutters, but usually the board serves to educate them. He has only seen one case (Ocean Ridge) where abutters came out against a cluster subdivision, and "it wasn't that they were against... the cluster subdivision concept." What they were concerned about was after two years of work, everyone had finally agreed on a subdivision and it was all approved. Then the developer came back with a cluster plan for the second phase. Mr. Stratford felt 
that first it would be "economically crazy" for the developer to do this because he would have had to do all of the engineering work and approvals over again.

Secondly, he said that the people who bought in the first phase felt that a cluster with its smaller lots would reduce their property value.

An example he gave of a "horrible" cluster is "Oak Forest" on Oliphant Lane (built ten or twelve years ago, just after the cluster ordinance went in). He said that "we [the town] got beat up on that one... maybe we weren't quite up to speed on what a cluster subdivision should have been at that particular time; we let that one fall through the cracks." He said that there isn't enough open space and that what is there is not in the right locations.

He thinks that the present regulations are "pretty good... some people disagree with me but everybody's got a right to their own opinion." He thinks a small density bonuses should be reinstated. He feels that this is needed as an incentive because "there are circumstances in a conventional where [the developer] would not have to spend that much more money to but in the infrastructure... versus a cluster and some developers just don't understand clusters... they don't want to know; all they want to know is how much money I'm going to make."

When asked if there were any provisions in the regulations that hindered cluster use, he noted that it wasn't allowed in the larger lot size zones. He said that the rationale behind that was that with the larger lot sizes, cluster isn't needed because there is plenty of pervious surface. He then started to describe a limited development concept proposed by some people in town where with a very large 
block of land (say 100 acres) a developer would be able to divide it into five-acre per unit density and cluster the units in groups of three or so around the large parcel, saving the remainder for agricultural use or horses, for example. They would have a smaller lot size, but the "rest of the land would be dedicated to agriculture and also give them relief on their taxes. That's one of the things I think we should look at. And something like that might keep the infrastructure from traveling out into our less populated areas, too" (Stratford 1997).

He thinks the biggest objection or barrier to cluster development "is a lack of education... the developers should be a little more in tune with what a cluster subdivision should be [rather than] looking at the dollars and cents." He feels that developers should bring very preliminary sketches and ideas into the town administration (planner, administrator, and public works) before they have anything invested in them so the town can show the developer the benefits of cluster and other creative development ideas and how much they could actually save. “Once something's started, [the developers] don't want to change, they can't see change and that's the sad part about it." 


\section{CHAPTER SEVEN: ANALYSIS}

For the purpose of analysis, issues and potential barriers to cluster development were divided into marketability and institutional factors. Marketability issues deal primarily with developer's perceptions of what they are able to sell. Marketability is affected by location, density, surrounding land use, previous experience, and present trends. It is also affected by the bank's willingness to finance certain types of projects. Institutional factors include planner and board member attitudes, state of current regulations, availability of incentives, the nature of the town's interaction with the developer, and conflict with other town departments.

\section{Marketability-Related Barriers}

\section{Homeowner's Associations}

Nearly everyone I asked about cluster's shortcomings or marketability limitations mentioned the drawbacks of homeowner's associations for buyers and towns. They named a few reasons for this. Buyers dislike being coerced into a collective. It is apparently an ideological issue, where individuals feel that they don't want longterm obligations to their neighbors attached to their home purchase. Prospective owners also worry about liability regarding the open space. Owners are afraid that they are opening themselves up to lawsuits from other residents, visitors, or outsiders that may get injured using common open areas or walking trails. 
Towns worry that the residents will not maintain the open space, and it will become an eyesore. The town does not want this responsibility. Buyers also do not want to, or cannot, pay for dues; they also worry about other buyers' willingness to pay. The last potentially negative aspect of a homeowner's association mentioned by interviewees is that some towns require the developer to put up a sign at the entrance to the subdivision stating that common land is owned and maintained by a homeowner's association. This seems like a stigma, but may be a status symbol to some people. It is a small issue, but the sign is very visible and unusual.

Larry LeBlanc supports homeowner's associations and deed covenants because they help preserve property values by assuring maintenance of the open space. He also sees them as a forum where residents can enforce deed restrictions related to personal property maintenance. He thinks that they only add value because they give residents control and make preserved and well-maintained open space possible.

Mr. LeBlanc seems to be correct, but it does not change the ideological issue. Some people simply want complete control of all land that they have an interest in, even if they do not really use it. If they cannot use the land, they feel that they have less than full ownership of it. Because of this, there will always be a market for conventional subdivisions. This view was expressed in some form by most interviewees. This ideology of "absolute land control" counts as a prominent barrier to cluster subdivisions. 
The liability issue is a less serious barrier. Insurance policies are available for homeowner's associations for very reasonable rates and are paid for as part of the annual dues. Once this is explained it becomes less problematic. The association can only be sued if the plaintiff can prove negligence, not for general accidents such as a hiker tripping over a root on a walking trail (Arendt 1994: 248).

The cost of association dues was mentioned as a marketability concern, and this seems to make sense. But when homeowner's associations are established correctly (with adequate enforcement but limited scope), they are generally not a burden when their sole purpose is to maintain open space. Associations charged with maintaining common recreational facilities such as pools and buildings are much more burdensome. The two most important aspects of a successful homeowner's association are automatic membership for all property owners and effective enforcement through the ability to place liens on the property of members who fail to pay dues (Arendt 1994: 247). While these aspects may discourage some, it seems a small price to pay for the benefits of protected open space.

\section{House Size Limit}

One developer mentioned cluster's limiting house size because of smaller lots as a potential shortcoming. A planning board member mentioned that sometimes large houses clustered together on small lots looks "kind of funny." Both of these concerns count as potential barriers, but both can probably be mitigated through 
design techniques. In Brookside, for instance, Mike Baker had no trouble fitting in very large houses because he retained sizable frontages. He was also able to avoid the development's "looking funny" through this method. Brookside, in fact, looks very much like a conventional subdivision. At the opposite end of the spectrum, if a developer wants to save maximum open space and minimize utility length, he/she could go to a truly "neo-traditional" design and pack large houses together on grid or modified-grid pattern streets. This would not look "funny" but familiar, since it is a traditional urban form of development beautifully illustrated in Portland, Maine, and many other well-preserved older cities (Duany and Plater-Zyberk 1992). These neo-traditional designs are not possible under existing regulations in either town, however. Regulations in both towns seem to be formed by a preconception of ideal residential environments that is at odds with the large, closely packed houses and modest setbacks of a Victorian-era neighborhood.

\section{Developer Inflexibility}

Sometimes developers simply insist on conventional subdivisions because of familiarity or perceived market need. Developers are more comfortable doing what they and their lending agencies are used to despite the fact that it conflicts with a planning board's established trend. Quail Hollow is a good example of this, where Mr. Cote had always built conventional and pushed for the conventional plan despite the planning commission's efforts. By all accounts he produced a very nice 
looking subdivision that took advantage of the topography and vegetation, but its biggest shortcoming is that natural open space is replaced by excessively large lawns. This, combined with many frontage lots and the three-year wetlands permitting process Mr. Cote encountered in Phase IV, suggests that both the town and the developer would have been better off with a cluster.

In Ocean Ridge, the developer really didn't have a choice to do a cluster even if that was what he wanted. Taking into account Mr. Warren's past development experience (all conventional subdivisions), the town's restriction of cluster to R-30 zones and smaller, and many developers' tendency to follow "the path of least resistance," there was little chance of this becoming a cluster. So why did the developer come back with a cluster plan? He would only have gained a few more units, not nearly enough to justify a whole new engineering and permitting process. Frank Boucher (who took the project over from Gerry Warren) stated that he proposed the cluster because he thought it was what the town wanted, it was better for the environment, and he believed the smaller lots were more marketable.

Unfortunately the site history and abutter resistance were too strong and his time and resources were wasted.

Another potential reason for a lack of openness to cluster is that perhaps developers project their own values on to the perceived customer. They want to build not only what they think will sell, but what they believe in and will carry out to the end. For example, if the builder and most of his/her friends are fiercely independent, they are not going to value a situation where they have to rely on the 
services of a homeowner's association. The HOA could be seen as a threat to their sense of freedom, and they may not want to impose this threat on others.

Charlie Silvia thinks that the largest barrier to good cluster subdivisions is lack of developer awareness and creativity. I think he would like to see developers come in with more creative ideas instead of trying to get as many lots as possible. The creative process requires both a supportive regulatory environment and willing and confident individuals however, and there are some measures that could be taken to improve the existing situation (see recommendations in Chapter Eight).

\section{Excessive Regulation}

Some developers complained about having to produce yield plans and multiple cluster concept plans. This can drive up the cost of cluster, but if the board prefers cluster, it is usually the best route and will save the developer time and money in the long run. The yield plan is "the cleanest, clearest, and fairest" method to determine conventional density, although some formulae produce comparable results (Arendt 1994: 235). A disadvantage to formulae is that they do not graphically illustrate how the conventional design will look, and this is a powerful tool to convince people of cluster's benefits. Both towns use yield plans and are satisfied with this method.

The issue of multiple concept plans is less straightforward. This does seem like a burden to the developer and does add some cost to the final product, but it probably 
helps the creative process and satisfies the board's curiosity to have several cluster configurations. They may like some features of each and ask the developer to combine them if possible. Mike Baker raised a point though, in saying that design issues should be left primarily to the developer because it affects marketability. The town has the obligation to protect both resources and residents, however, and therefore has a legitimate role in design.

\section{Overall Impressions}

All of the interviewees expressed that on the whole, cluster is more positive than negative. They also believe that cluster is marketable despite concerns over lot size and homeowner's responsibilities, but that there will always be a market for conventional subdivisions. Mike Baker summed it up well stating that these concerns are "issues" rather than barriers.

\section{Institutional Barriers}

\section{Development Regulations}

Planners and board members from both towns expressed satisfaction with their existing cluster regulations, but some named potential improvements. North Kingstown had just completed a draft of an updated zoning ordinance to make it consistent with the comprehensive plan. Marilyn Cohen said that her department 
and commission wanted more flexibility in their cluster regulations, and planned specifically to start exploring possibilities over the next month.

North Kingstown interviewees viewed their policy of subtracting constrained soils from developable area in cluster as a potential barrier, but the record shows that cluster has prevailed in almost all subdivision proposals since the early nineties. This trend substantiates their views on incentives; they haven't needed any density bonus or reduced infrastructure requirements to get developers to build clusters. It seems to have been purely the will of the board that produced cluster in so many cases.

One very interesting barrier voiced by Marilyn Cohen is the inability to do more creative land ownership arrangements that would reduce the tax burden on project residents but keep some tax revenue coming in. In particular, she mentioned an example of a cluster land ownership arrangement where a farmer owns the title but no development rights on the dedicated open space. This arrangement is not legal under the current Zoning Enabling Act. Similar arrangements can be made for agriculture with the homeowner's association retaining ownership, however, as is done in Middletown.

Charlie Silvia supports Middletown's regulations in general, but feels that the density bonus may not be necessary. He also feels that cluster should once again be an option for R-40 and R-60 zones. Bill Stratford has the opposite opinion, however. He opposes inclusion of low-density zones for cluster, and feels the density bonus is an important incentive. But Middletown does not seem to be getting enough for 
their density bonuses. Perhaps a compromise could be made between these two views where cluster would be allowed in all zones with a density bonus only if the developer agrees to follow a special set of design guidelines where maximum open space is conserved and the town can influence the character of the houses.

Cluster as Stimulus for Development

Some board members expressed that they may be afraid of cluster in large-lot zoning because they see it as a way for a developer to develop where they normally could not. For instance, some people argue that two-acre and larger lots discourage development because land costs and large frontages (requiring more costly utilities and longer roads) make development less economically attractive to developers. It follows from this argument that the savings that result in a cluster design short circuit the growth-retarding effect supposedly gained from large lots. One shortcoming with this argument, however, is that if market conditions are right (and they certainly have been in North Kingstown at least in two-acre zones), the land gets developed anyway. Quail Hollow is a good example of this. The market is apparently able to accept its large houses on two-acre plus lots, costing between $\$ 350,000$ and $\$ 450,000$. The argument may hold true in lower density categories, where for example five-acre zones with three-hundred foot minimum frontages probably do control growth by discouraging subdivision development (Eccleston 1997). These large lot sizes do not discourage development on existing roads, 
though, which can erode rural character as every frontage lot is eventually developed. If a town wants to remain rural it should have true rural zoning densities such as one unit per twenty acres (see Chapter Two for discussion of appropriate rural zoning densities). One option is to limit clustering to two-acreand-under zoning districts, where development will most likely occur anyway, and keep five-acre or larger lots in other areas perhaps with minimum setbacks to preserve views on designated scenic roads. However, none of these solutions is a substitute for good regional planning with designated conservation and growth areas backed by solid regulations and programs (such as urban growth boundaries, transfer of development rights programs, and impact fees). This is a critical issue, but further discussion is beyond the scope of this paper because the subject towns are poised for inevitable growth.

\section{Incentives}

The general consensus from North Kingstown was that incentives are generally not necessary; shortened utilities and the ability to handle environmental constraints better provide enough incentive to make cluster more profitable. This was true even in the Brookside case study, where the developer was still able to get the large frontages he felt he needed for marketability.

In Middletown, Bill Stratford expressed that he thinks the density bonus is an important incentive for cluster. He thinks it is necessary because in some cases there 
is little difference in street layout between a cluster and a conventional development, and it doesn't make sense for a developer to go through the bother of designing a cluster if he or she is not going to save any money. In the case of medium to high density developments this is probably true, but in lower density zoning this seems unlikely. Higher-density clusters are probably what Middletown is used to, though, and this probably forms their perception of cluster in general.

Mr. Stratford's point about lack of infrastructure savings could be applicable for some of the more "cutting edge" rural subdivision designs where fields are preserved and houses are clustered towards the rear of the property (if sewers are even used). A long road and utilities are needed to reach the houses, negating any savings gained from clustering. In cases like this, the town would have to provide other incentives such as reduced road width and drainage structure requirements. I would not recommend allowing above-ground utilities due to their visual impact. This "field preservation" design may clash with Mr. Stratford's concerns regarding distribution and usefulness of open space, however. Creative design could provide a compromise, but the town's open space goals need to be taken into account.

Perhaps it is not realistic to think some rural character can be preserved in any of the remaining R-30 and under zoning districts. The town would have to study this by drawing up concept plans on actual parcels. It seems more possible to save rural character in the eastern part of town, where Mr. Stratford feels eventual sewer extension and upzoning are "a given." This is where incentives need to be considered. Perhaps these areas could be subject to an overlay district with special 
design guidelines for rural clustering. These guidelines could contain architectural standards, flexible setbacks and frontages, reduced road widths, and specific open space and vegetation requirements that would enhance the character of the development and conserve maximum open space (see recommendations in Chapter Eight).

Randall Arendt (1994) argues that short of mandating open space/cluster design, a board can provide other incentives such as density penalties for developers that insist on conventional subdivisions. In light of benefits from reduced infrastructure and smoother permitting process, this is probably unnecessary and would probably face strong opposition.

I get the impression that Middletown interviewees feel that they receive few benefits from cluster. The open space is typically small, odd-shaped, and unusable, causing an unrewarded maintenance liability. Because of Middletown's landscape of open fields, there is really no way to retain density while saving natural appearance or open areas using the present regulations because there isn't enough mature vegetation to break up fields of view. A tight village concept such as that used in Pennsylvania (Arendt 1996) might work in the largest zoning categories where cluster is not an option, so the regulations would need to change in this regard. They would also have to provide more dimensional relief to get the closeness of a village, specifically side and front yard setbacks. This would be a very special development for a specific clientele that may not exist in Middletown. Middletown is very different from North Kingstown socio-economically. The 
present market consists mostly of "starter home" buyers interested in as much usable land as possible within their small lots. People can only buy what is available, however, and it seems few developers will take a chance when there is so much conventional competition.

Another opinion that was universally held by interviewees is that cluster allows the developer to handle environmental constraints better, making permitting easier. This is particularly true with wetlands, where the buffers provided by cluster reduce the typically lengthy state permit review time. Several of those interviewed saw this as so strong an advantage that other incentives aren't necessary.

\section{Disagreement Between Town Departments}

One of the most important barriers to creativity in subdivision design mentioned primarily by developers and hinted at by others is disagreement among town departments over road, drainage, and other standards (LeBlanc, Baker 1997). Some planners and board members tend to favor reduced road width to reduce cost and amount of impervious surface. Public Works Departments tend to favor wider roads for safety and ease of maintenance. North Kingstown has reduced its minimum road width to twenty-four feet (including one foot Cape Cod berms on each side), but according to Charlie Silvia, the Middletown planning board remains "hard and fast" at twenty-six feet. 
Randall Arendt and others discuss this issue extensively (Arendt 1994;

Southworth and Ben-Joseph 1995). This is a complicated issue, but in the end it comes down to town priorities and particular site characteristics. In some creative designs, street usage and arrangement may allow reductions in width and drainage requirements. Both towns in this study should examine their policies of planning for the worst-case scenario while sacrificing livability, the environment, and the developer's purse (which is reflected in housing prices). They also need to weigh how reduced standards might encourage development.

\section{General Questions}

Is North Kingstown's ordinance producing good clusters with sufficient open space? Is Middletown's? What constitutes a good cluster? In North Kingstown's case, emphasis seems to be placed on preserving natural areas. At least that was the result of the low density example from the case study. In Middletown, where the case's density was greater, more emphasis was placed on use of the open space by the residents. This is supported by language from the ordinance: "The principal purpose of the open space is enhancement of the residential environment, and is restricted to the use and enjoyment of the residents..." This can be taken a number of ways, but priority of human use for open space was also emphasized by Mr. Stratford when he was discussing the example in Middletown where the open space is all to one side of the development and is used for agriculture. 
There seems to be a fundamental conflict between Middletown's desire for rural character as expressed in the comprehensive plan, and the apparent demand for dense affordable housing as demonstrated by its apparent willingness to upzone and allow sewer extensions. Perhaps rural character can only be achieved with townhouses hidden in the trees, or multi-family dwellings disguised as rambling farmhouses (Arendt 1994: 159).

\section{Board Attitudes}

Perhaps the most substantial barrier is the potentially distrustful and contentious relationship between the board and the developer. Some of the attitudes I heard betray an inherent distrust of developers motives. This distrust is shared by boards and citizens alike, and acts as a barrier to the two parties working together (cooperation is crucial to creative clustering). Board members don't want to be seen acting "buddy-buddy" with developers, because of the ever present innuendo that something is going on behind the scenes (Boucher 1997). Without cooperation and proactivity on the board's part, subdivision review takes on the flavor of a court proceeding, and what could be a creative design process becomes a rigid clerical exercise. Perhaps this is the way some boards would rather have it, because it is less challenging and takes less time and commitment.

Board attitudes have complex causes. They may stem from fear of the unknown juxtaposed to fear of having another bad experience in a seemingly similar situation 
(not wanting to be seen as making the same mistake again), unwillingness to take a chance (uncertainty), lack of confidence in the regulations being strong or flexible enough to get what the town really desires, or unwillingness to speak against current planning board or commission trends.

The board may be unwilling to pull together and advocate the cluster technique because influential board members may not feel the town is getting enough benefit, even though all of the board members generally accept cluster's benefits. Another factor might be unwillingness to withstand political pressure from people who are unaware of cluster's benefits, because no one on the board had solid positive examples to give or studies to cite. It would seem difficult to erase a readily admitted unsatisfactory past record, as in Middletown's case. Neither can we ignore the town's needs. The two towns are different both geographically and demographically. On the whole Middletown has a more mobile, less wealthy population that requires a less expensive housing stock. This is reflected in both Frank Boucher's comments at the July 11, 1996 Planning Board meeting about having trouble marketing acre lots, and William Stratford's comments about inevitable upzoning and "who the hell wants to cut grass on a sixty-thousand square foot lot."

It seems apparent in Middletown that Mr. Silvia, Mr. Stratford, and the board want the benefits of cluster but don't have the confidence in their regulations to get what they want. Mr. Silvia and Mr. Stratford both specifically expressed dissatisfaction with the configuration of open space in past clusters. They modified 
their regulations to prevent this problem in the future, but it is difficult to tell from the case study if the regulations are making any difference. One positive sign is the dialog that occurred during the meetings on Valley View regarding the open space. The minutes indicate concern from the board members over open space configuration and plantings, which seems to have been addressed as best they could considering the developer's inflexibility with the road layout. The regulation's language supports this conclusion:

"Arrangement of buildings must be environmentally sound with reference to continued groundwater and surface water quality and with reference to unique site features... Open space arrangements must be beneficial to the potential residents of the Cluster Development or the public at large... The arrangement of buildings, lots, and site plans must take into account the characteristics of the parcel and of adjacent land use. Buildings must be arranged in a way to ensure a harmonious blending between them, including adequate protective buffering."

More than others, smaller-lot subdivisions require clever design and flexibility.

This is a dilemma. If, in lower cost subdivisions, developers are less willing to hire design professionals to work with their engineers, then the result will be a purely "engineered" design. As Larry LeBlanc aptly stated, engineers tend to be "driven by geometry." If the town is unwilling to require a "design team" made up of engineers, planners, and landscape architects (which would most certainly be a barrier if only required for cluster), than the job (perhaps the duty) of good design rests with the planning department and planning board.

This raises the question of what level of comfort the planner or board feels with design, and also how willing are they to advocate a mutually derived design in front of an angry public. Based on interviews, abutters object not to cluster in particular, 
but rather to any development at all. They appear in most cases to receive cluster the same or better than conventional development once the concept is explained. If the developer can explain how the concept works in the plan with the help of the planning board, then creative design might be better accepted not only by citizens, but also by public works, the fire department, and environmental interests.

The Most Prominent Barrier

In the end analysis, the most prominent barrier to effective use of cluster development seems to be the planning board's attitude. From the comments of both developers and planning staff, the notion of "the path of least resistance" is prominent. Time is so important to developers that they will do everything they can to cooperate with the board and follow established trends. If that trend does not favor cluster for whatever reason, a developer is unlikely to propose it. 


\section{CHAPTER EIGHT: RECOMMENDATIONS}

Recommendations are organized according to issues or "barriers" identified in the analysis. Many recommendations are based heavily on ideas compiled or formulated by Randall Arendt, Elizabeth Brabec, Harry Dodson, Christine Reid, and Robert Yaro in their book Rural by Design. Many of the recommendations are aimed more towards Middletown, where judging from the interviews there is apparent dissatisfaction with cluster for a variety of reasons. North Kingstown, despite its apparent success with cluster, may want to examine some of the ideas presented. They may in fact already exploring some of the ideas, as expressed by Ms. Cohen and Mr. Whitaker in their interviews.

These recommendations only respond to issues brought to light by the series of interviews. They are by no means comprehensive, as there are many important details that are beyond the scope of this research project. I refer the reader to the many sources listed in the References/Bibliography for the project. Of particular interest is the Scituate Reservoir Watershed Zoning Project by the Newport

Collaborative Architects, et. al., and Portsmouth, RI's "Residential Open Space Development Ordinance." These are both examples of innovative development design in the Rhode Island context. 


\section{Homeowner's Associations}

Homeowner's associations stood out in interviewees minds as a significant potential barrier to cluster development. Basic recommendations follow, but for a thorough treatment see The Homes Association Handbook ( Hanke, et al. 1974).

Buyers Concerns (Anticipated by Developers)

\section{Coercion}

Fear of coercion, or unwillingness to buy into any collective organization, is a serious ideological barrier to cluster developments because of the need for at least a minimal homeowner's association. In order for a homeowner's association to be successful, mandatory membership and deed-backed enforcement power are required (Arendt 1994: 247). These tend to raise the ire of more independent souls. Some individuals simply will not subject themselves to this type of authority. The best thing the developer can do while setting up the association is to limit its scope and authority in the agreement referred to in the deed according to the demands of the particular market sector the developer is aiming for. The "minimal" association should only be responsible for specific maintenance tasks such as mowing grass and other small maintenance items. The developer should think carefully about further maintenance responsibilities and enforcement powers, such as appearance controls and personal property maintenance provisions. Some prospective buyers and residents are apt to resent these types of controls, while others will wholeheartedly 
support them. This depends on what type of market the developer is targeting. It is the developer's job to study the market and then clearly explain the services and benefits provided.

\section{Liability}

Fear of liability is a legitimate concern in cluster developments because the open space is for common use and it is difficult to control access by non-residents (if the association is so inclined). Fortunately, insurance policies are available at reasonable cost (Arendt 1994: 247; Whitaker 1997). Insurance claims are rewarded only if the plaintiff proves that the association was grossly negligent. To avoid such liability, facilities have to be carefully maintained. The best policy is to keep common property in a nearly natural state. If common recreational facilities are present, they should be kept simple for ease of monitoring and maintenance.

\section{Cost}

Costs are directly related to the type of common property. Naturally, facilities such as pools and recreational buildings cost more to maintain than lawns and natural areas. As stated above, associations should provide services according to market niche. Rich retirees, for instance, are going to demand a different level of services than a starter-home population. The best policy at any level is to keep it as 
simple as possible and to clearly state the costs and services involved. Prospective buyers will seek out what they are comfortable with.

Roads present a dilemma. Private roads can provide more flexibility in width, slope, and drainage facilities. Towns will generally not make such "substandard" roads public, leaving homeowners with the cost. Towns should explore their road requirements and consider relaxing standards for width and drainage where conditions are favorable (such as low-traffic roads in areas with good natural drainage characteristics).

Stigmatization

This refers to some towns' policy requiring a sign at the front of the subdivision stating that "Common land is owned by a homeowner's association." Towns should reconsider this requirement and explore possible alternatives, such as placing smaller signs at various points around the outer edge of the open space so that trail walkers and other non-residents can see them. The inner boundary could be subtly delineated with small concrete markers to discourage resident encroachment on open space if necessary. 


\section{Maintenance}

Interviewees and literature revealed that municipalities are sometimes afraid of cluster because they do not want to be left maintaining open space and roads by neglectful homeowner's associations. This can be avoided by clear language in the deed or association agreement that assigns responsibility. This fact should be clear to all involved parties. The agreement should specifically give the town power to perform maintenance and attach liens to the owner's deeds if the association fails in its duties.

All of these ideas are very basic and the towns and developers seem to be aware of them. One final suggestion is to make information available to developers, board members, and the general public contrasting "successful" and "unsuccessful" associations. It could also list resources for anyone creating or charged with running an association. This could be in pamphlet form available at the planners, assessors, and code enforcement offices. 


\section{Developer Inflexibility}

\section{House Size Limit}

Several interviewees mentioned that the smaller lots resulting from cluster limit the potential house footprint size, and that this is a barrier to cluster for some developers. Design flexibility may alleviate this problem; it depends on underlying zoning, site characteristics, and house size. One potentially useful design solution is to vary the lot sizes in a cluster according to "desired" house size and yard size. For instance, some people do not want a large yard because of maintenance, while others like to mow their lawn and have lots of usable space. With a small plot size, land could be given over in the design to other large houses and yards, with common open space providing views and "openness." This would be a mixture according to need.

\section{Privacy}

Some developers are hesitant about cluster because they see smaller lots as less marketable. This is because prospective buyers oftentimes don't want to see houses when they look out their windows. People think they can answer this problem with large lots, which in the end are more difficult and expensive to maintain for the homeowner. A better solution is obtained by clever vegetated buffering between residences while preserving views of preserved open space (Arendt 1994: 231). Trim's Ridge on Block Island provides a good local example where houses are 
grouped in pairs on small buffered lots (Arendt 1994: 349). While vegetated buffering does not reduce noise, the distances gained from conventional lot sizes makes very little difference compared to compact lots. All development interests should realize that buffering and other design solutions can provide privacy while maximizing open space views and protecting natural resources.

\section{Institutional Barriers}

Incentives

The general consensus from North Kingstown interviewees and all of the developers is that shortened utilities and the ability to handle site constraints better provide enough incentive to do a cluster rather that a conventional subdivision. Middletown interviewees took a different view. Charlie Silvia recognized these advantages, but felt that sometimes the developers think that they do not provide a sufficient incentive because in some cases the utility savings are not enough to overcome perceived extra time and work to do a cluster. Bill Stratford supports the density bonus and sees it as a powerful incentive. With or without bonuses, however, the cluster technique should always benefit the town in some way. For example, cluster should always result in shared and usable open space, and it can also be used to improve development design and produce more affordable housing units. 


\section{Density Bonuses}

Towns should begin with goals for clustering that designate location and potential incentives according to clearly stated priorities. They should start with a standard cluster ordinance outlining baseline performance standards with no bonuses if they think they can get cluster in the locations their goals proscribe. Density bonuses can be a powerful incentive, but Middletown does not seem to be getting all they potentially could with this method. The findings indicate that they probably can get standard cluster subdivisions without a bonus. Towns should consider granting density bonuses only if they are getting an additional benefit from it. For example, bonuses could be an incentive for the developer to accept special design standards for the site and houses. They could also be an incentive for affordable housing, for which the town could also have special standards so that development matches the character of the community.

Density bonuses would provide an attractive incentive in exchange for hiring a design team. Towns should use incentives to create a different quality of development that will break and modify trends they currently follow. Once the trends change, towns might scale back incentives.

It order to obtain substantial concessions, the density bonuses would probably have to be in the twenty-five to thirty percent range. This seemingly large increase is necessary to entice developers away from familiar and comfortable (though not beneficial) development types. Also, the majority of rural and suburban developers 
in New England have not responded well in the past to bonuses in the ten to fifteen percent range (Arendt 1994: 229).

\section{Development Regulations}

Both towns expressed an interest in exploring "more flexible" regulations or more creative development and land ownership schemes. There are at least three distinct steps to changing the regulations to get what the town really wants: education, exploration/formulation, and advocacy.

\section{Education}

The first step is for the planning staff and entire planning board to educate themselves on the latest creative open space/cluster design techniques used in Rhode Island and other parts of the country. iii Workshops are useful for this especially if they are split between a dynamic visually-aided presentation and a practical component where participants can "get their hands dirty" designing a subdivision according to creative design principals. This is best done with an actual site in town which is slated for development. It could also be done for a site already developed with existing standards to show the town what they could have gotten instead.iv

After one or two of these workshops, participants will be more familiar with rural/open space design principals. Please keep in mind that in a cases like 
Middletown and perhaps even North Kingstown, professional and lay-planners may want to consider having a similar workshop on "neo-traditional" design concepts that may be more appropriate in denser zoning districts. Neo-traditional concepts also are very useful for infill development in some areas where character preservation is important.

\section{Exploration/Formulation}

In the second phase, planners and board members armed with fresh ideas need to explore how the ideas apply to their community. They have to determine the particular elements of landscape and streetscape they want to conserve and promote so they can begin to formulate performance standards. It is essential that the board and interested citizens evaluate their town's character for themselves using visual aids and sample measurements. They then should design regulations practically from scratch using concepts and perhaps only a small amount of language from other ordinances. The main point is that you can not just take an ordinance from another place and expect it to work (Gilstein, 1997). Provisions have to be developed and tested (as stated by Lee Whitaker and Marilyn Cohen) to fit an individual municipality according to clearly articulated goals. It is also essential in this stage that the planning board work closely with the town engineering department so they can arrive at realistic standards. Input is also necessary from the conservation commission and historic/cultural preservation interests. 


\section{Advocacy}

The third stage is very related to the second stage, in that the planning board and department had to carry the ideas forward and advocate them among the town departments and other interests. The next step is for the board to advocate the new techniques to the town council. Education through dynamic presentation is essential here. This will require a full visual presentation and handout materials summarizing the technique, how it is different from conventional and the standard cluster development provisions, and what the town stands to gain. When regulations are finally approved, the town will have to then sell the idea to developers with assurance that once they enter the process, they have certain vested rights to principles agreed on in the preliminary plans developed with the board. This will help alleviate the fear that they will invest engineering into a plan that the board might renege on.

An additional approach is to convene a statewide meeting of builders, public safety officials, consulting engineers, planners, and landscape architects to reexamine common subdivision standards for different kinds of development. They could produce a report such as "Best Practices Manual for Cluster and Rural Subdivision Standards" and perhaps propose changes to the State Enabling Legislation if necessary. 


\section{Lack of Coordination Between Town Departments}

Lack of coordination or disagreement between town departments was apparent as a potential barrier to "more creative" cluster subdivisions and other innovative forms of residential development. Planners and board members did not state this directly, but they did say that they are interested in more flexible regulations. The developer's general sentiment is that road and drainage requirements are "overengineered" and represent a "bureaucratic mentality that this is what the regulations say and whether it makes sense or not that's what we've got to do" (Baker 1997). It seems that planners, board members, and developers would like to do something more creative, but strict standards defended by the town engineering department stand in the way.

I recommend that both towns re-examine their road and drainage standards and modify them so they serve their purpose according to actual use and context. This would almost certainly reduce road width, lessen the amount of structured drainage, and retain a more natural landscape through less strict grade requirements. All of these measures can potentially preserve rural character and create a safer development. ${ }^{v}$

There also seems to be a lack of face-to-face contact between representatives of various departments during the development review process. Most contact seems to be through correspondence rather than at a meeting where changes can be negotiated all at once. A meeting with representatives from several departments may be difficult to coordinate, but the effort is worth it. After all, once the formal 
engineering starts, it is less likely that the design will substantially change. Many interests should have an active role. The meeting may be difficult to manage, but the product should be better.

\section{Modified Standards}

First off, because modified standards will probably reduce construction costs, towns can use the "reduced standards package" as an incentive to get the developer to formally agree to other measures that will preserve rural character, produce a more attractive development, and protect environmental resources. The largest concession would be for the developer to hire a professional design team with a site planner, landscape architect, and engineers that will work together to produce a truly creative result. This design team would have to be present at a preliminary meeting with certain involved parties so they can negotiate appropriate requirements (set according to performance standards). Perhaps cooperation and joint design is too much to ask of boards at a board meeting, but some board members could meet with the planner and developer to help clarify what the town desires. The next step in the process should be a meeting including town engineering, fire department, conservation commission and cultural/historical interests. This less formal setting allows genuine interaction and consensus building. This will reduce delays and conflict later in the process because the 
developer will have invested time and resources into something all parties can agree on, rather than trying to push a preconceived design on an unwilling board.

\section{The Need for Regional Planning}

Cluster and other creative development are good design techniques, but planners and decision makers have to keep in mind that design is no substitute for regional planning. If communities want to conserve natural and cultural resources, they have to take advantage of the full range of planning tools that are available. As illustrated in the Arendt and Daniels debate discussed in Chapter Two, creative design is only a second or third-best solution in some situations. Creative development techniques should be combined with agricultural zoning, urban growth boundaries, transfer of development rights (TDR's), and special protection overlay districts whenever politically feasible and environmentally appropriate. All of these tools serve well in a strong network of regional planning, a phenomenon that is rare to non-existent in New England.

\section{Limitations and Implications}

The main limitation of the study was that there were only four cases and two towns involved, limiting the breadth of its implications. In addition, the cost and underlying zoning differed substantially between Middletown and North Kingstown. The cases are, however, good examples of the type of development each 
town will continue to face due to land availability and the housing types demanded by the market. Two missing elements that would have been both interesting and useful are perceptions of residents and abutters of cluster developments. Perhaps a market survey is in order. Other useful studies would be a national or regional level quantitative survey of perceptions towards cluster and other creative development techniques or a state-level study of cluster regulations aimed at gauging cluster's effectiveness in conserving natural resources and elements of community character.

While case studies were only done for two Rhode Island towns, the basic findings of this project are probably applicable in most of New England and much of the country. The marketability and institutional issues seem like they may be common and would probably hinder creative development universally. If this is true, than there is a call for cluster/creative design advocates nationwide to educate planning interests and decision makers and participate in the ongoing debate between conventional boilerplate and creative possibility.

\section{Final Notes}

This research project contributes to the study of development by at least attempting to go beyond the arguments of experts and proscriptions of textbooks to the world of practicing planners, board members, and developers. Their opinions and perceptions are very meaningful to examine because they represent reality at the level of practice. While not always "objectively" accurate, perceptions convey great meaning and inform efforts to educate. 
i This is admittedly a broad and open-ended question for a research project of this scope, but I had originally counted on narrowing it down through the literature review process. My hope was that studies of this nature had been done in other parts of the country and that I could use these existing studies as guides. After a thorough literature search, I have come to the surprising conclusion that no studies of the type I envisioned have ever been performed and published in scholarly journals. The search included computerized sources such as ERIC, PAIS, the Expanded Academic Index, and CARL Uncover using many different euphemisms for cluster development and related terms. I also looked in the CPL Bibliography (315- Cluster Development), Sage Urban Studies Abstracts for the years 1990-1996, the Journal of Planning Literature for 1991-1994, and the Journal of the American Planning Association back to 1975. In addition, I looked in the references of every publication on cluster and site planning I could locate.

ii Severely constrained soils are subtracted from the buildable lot area in cluster following the rationale that it is more difficult to site a septic system on the smaller lot.

iii Rural or Open Space Cluster Ordinances were recently adopted in Scituate and Portsmouth, RI, but no projects have yet been built. Trim's ridge is a reasonably good example in.New Shoreham (Block Island), RI, but the town's cluster ordinance still requires one-hundred foot frontages which limit flexibility (Arendt 1994:349). Good examples can be found in Massachusetts, Connecticut, Pennsylvania, New Jersey, Vermont, Delaware, Maryland, Virginia, Michigan Illinois, and Colorado (Arendt 1994: 315).

iv It would be a good idea to have a site planner, landscape architect, and engineer (one sympathetic to creative design) present to guide participants and act as a "reality check," particularly with drainage issues.

"The development will be safer because reduced road width and curb radii effectively reduce the speed at which drivers feel comfortable. Wide streets designed for roadside parking where this type of parking is rarely used actually encourage speeding, endangering children and pets (Arendt 1994: 178-183). 
APPENDIX A: FIGURES 


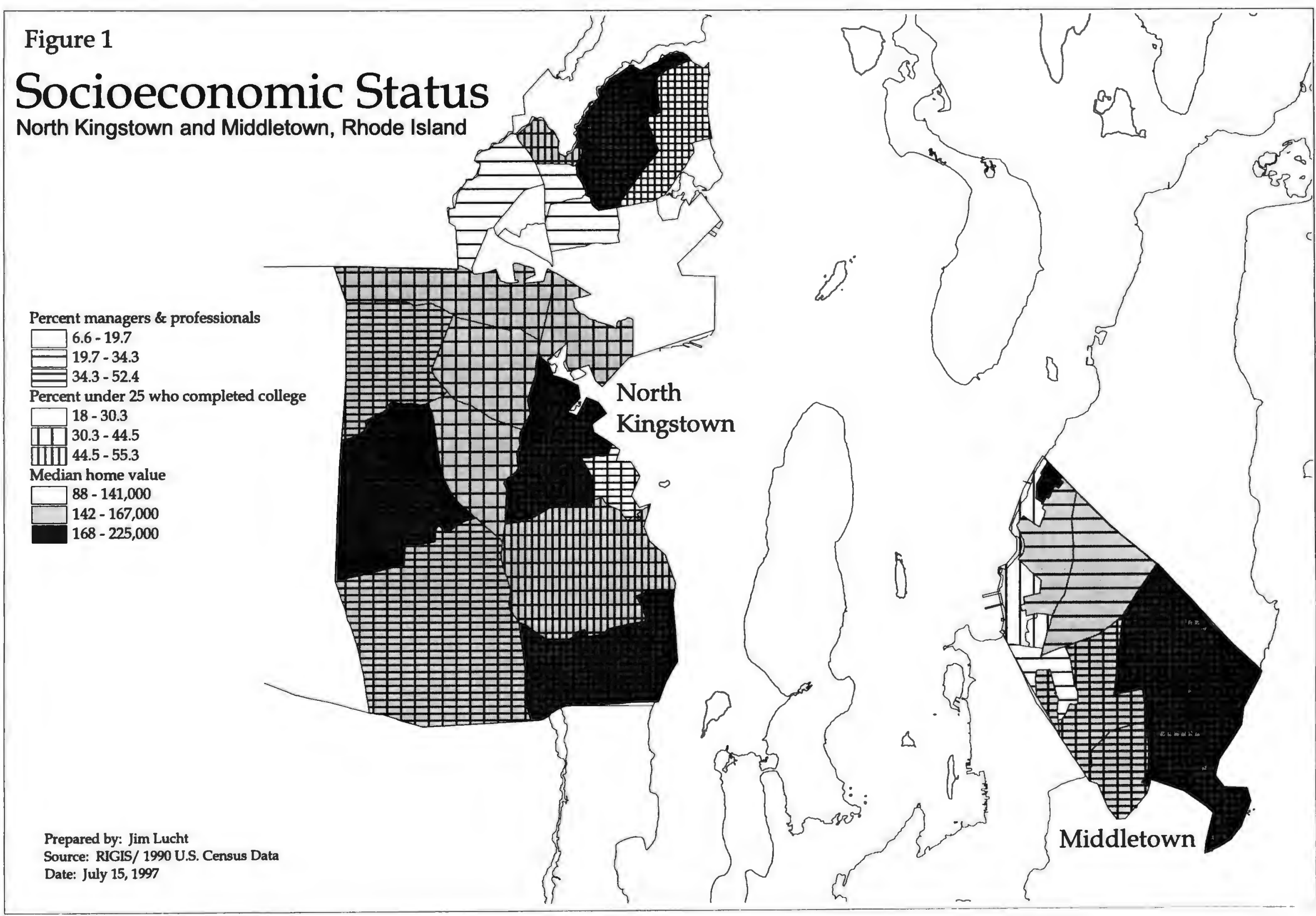




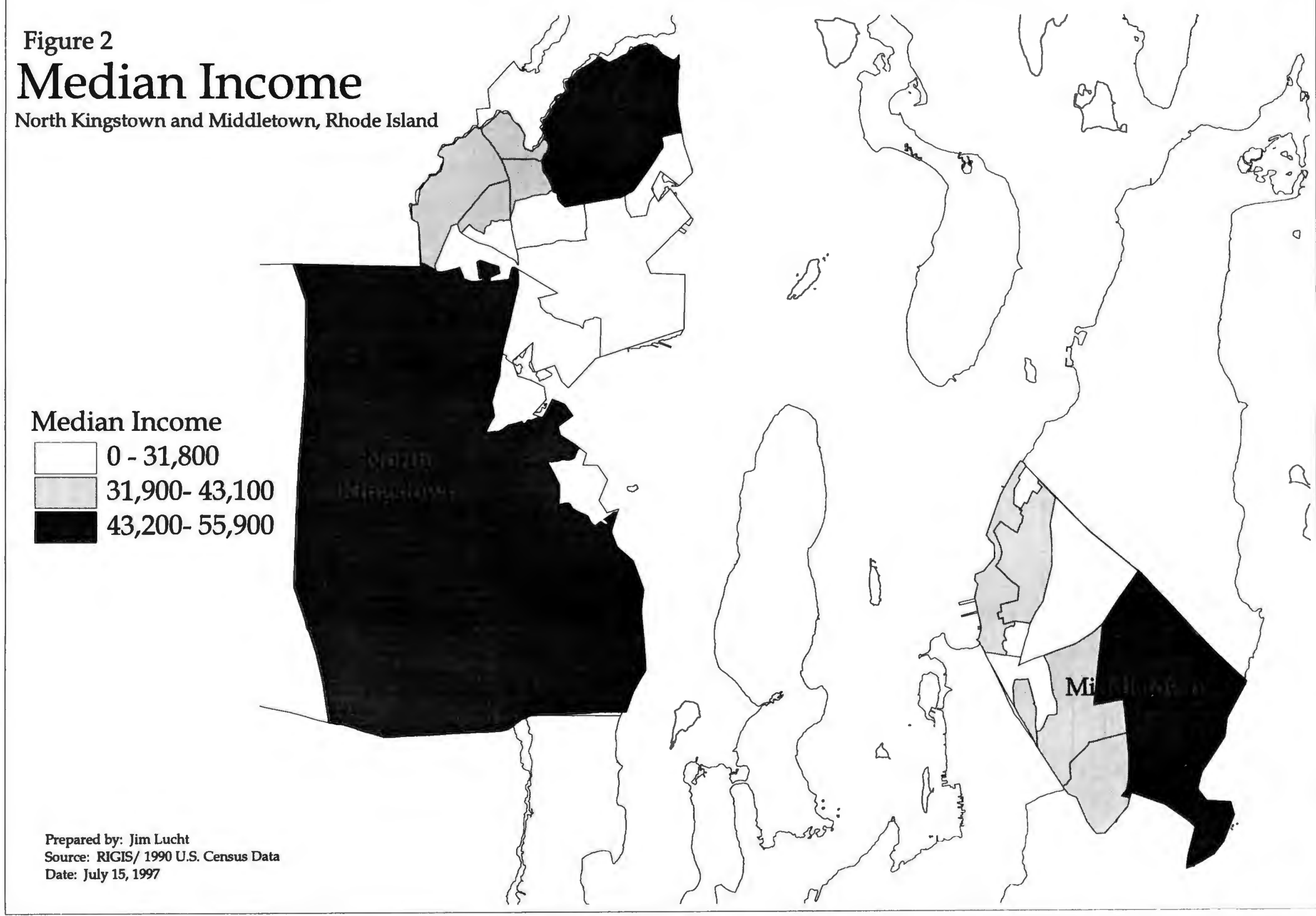




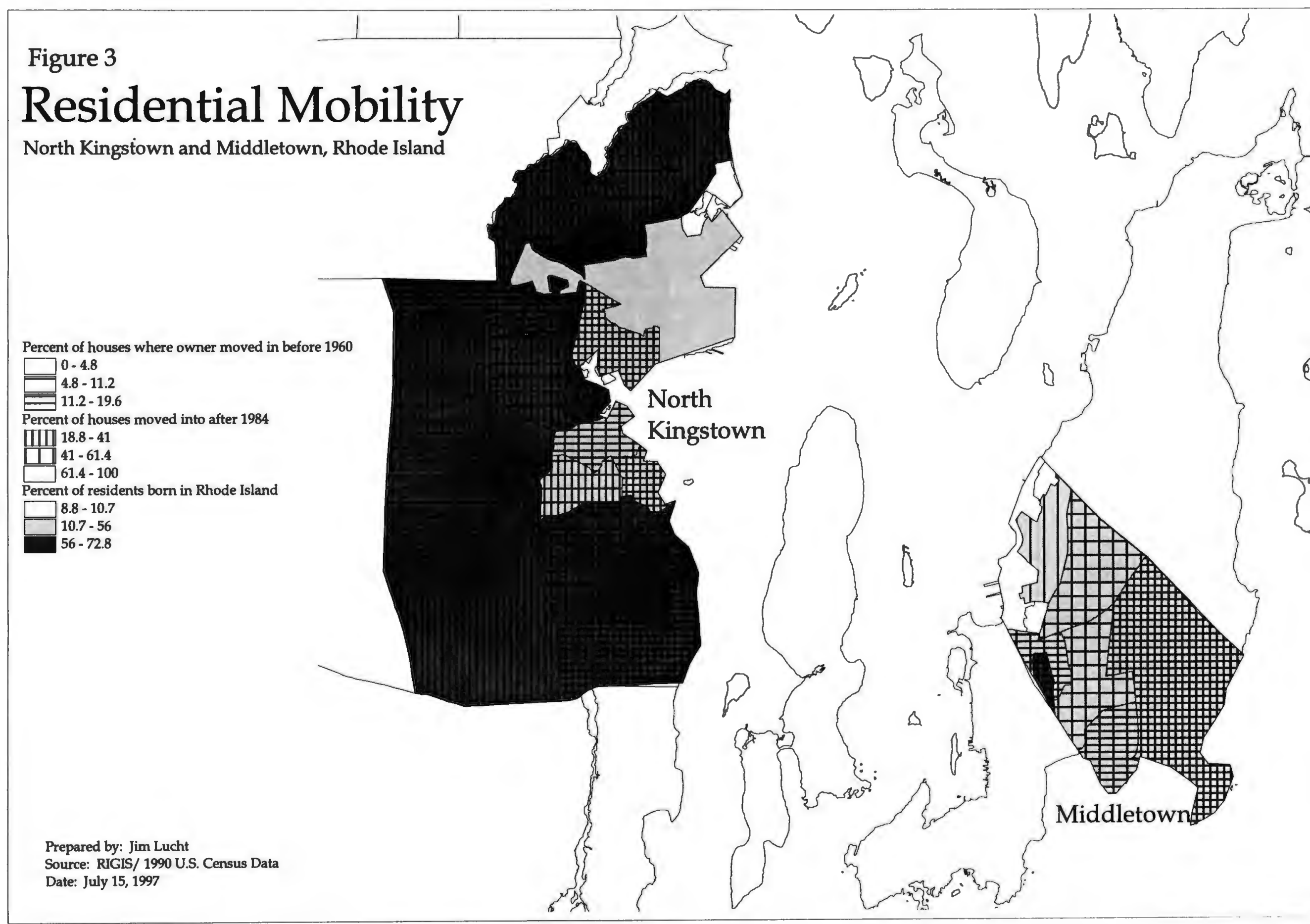




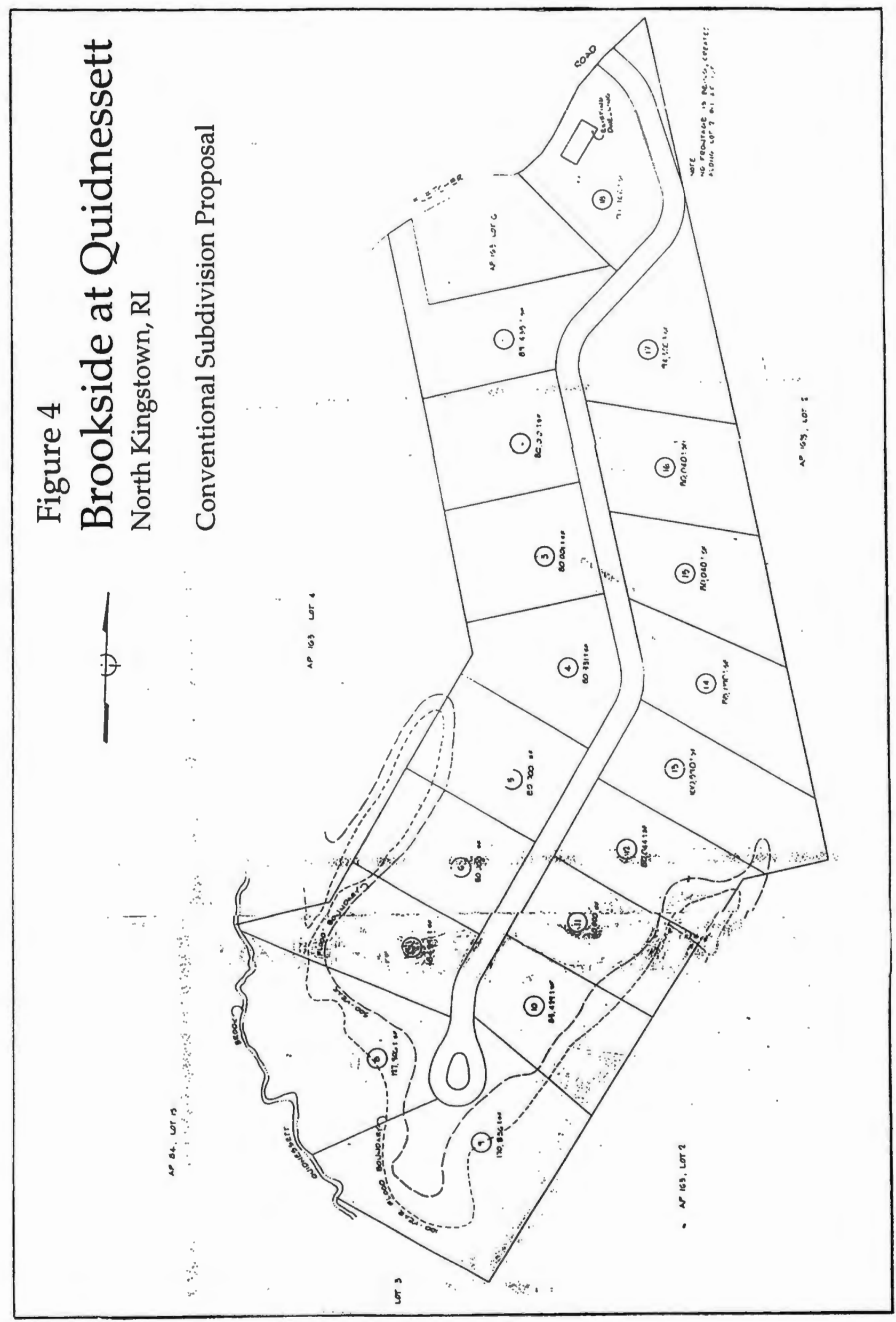




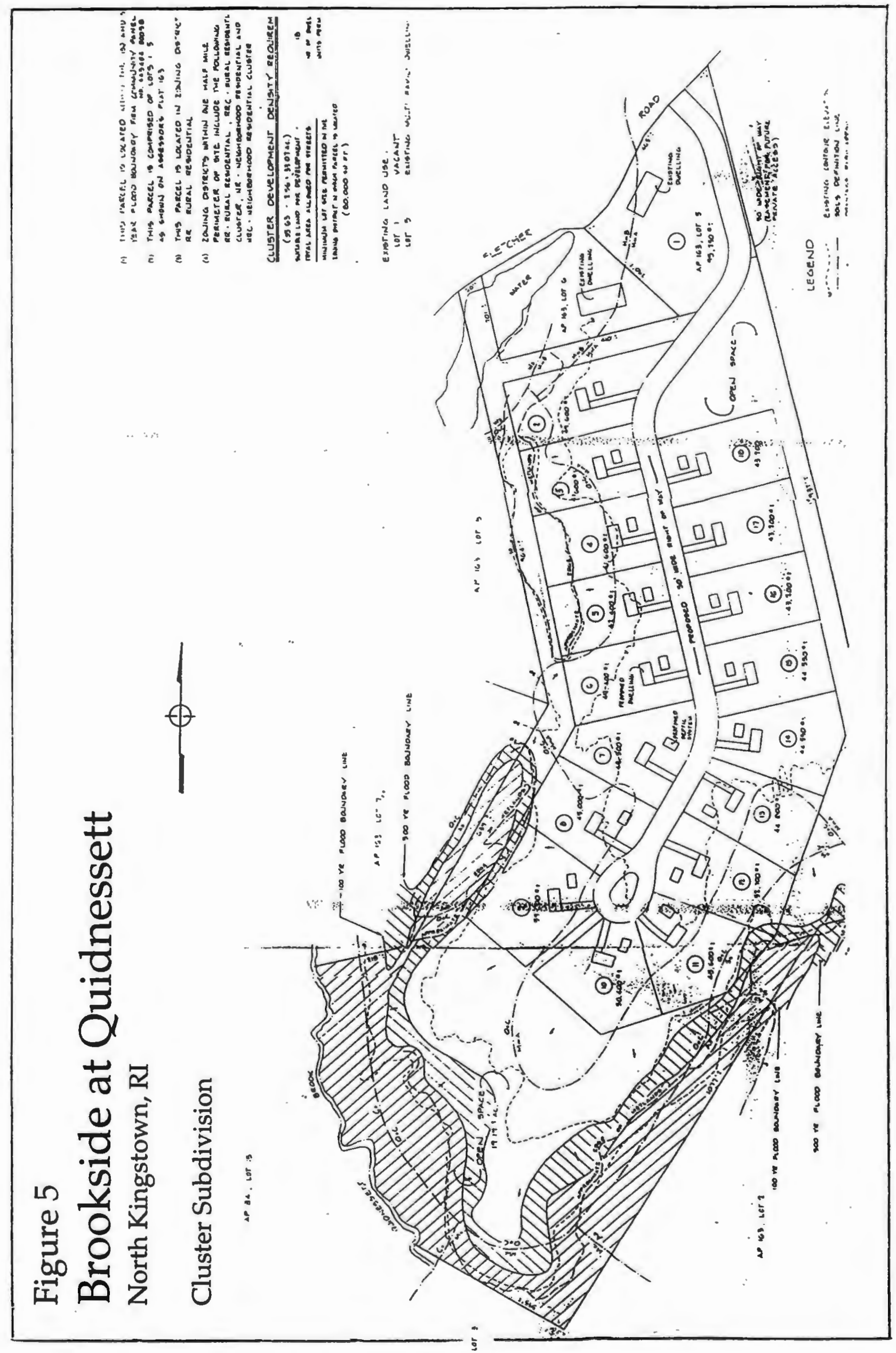




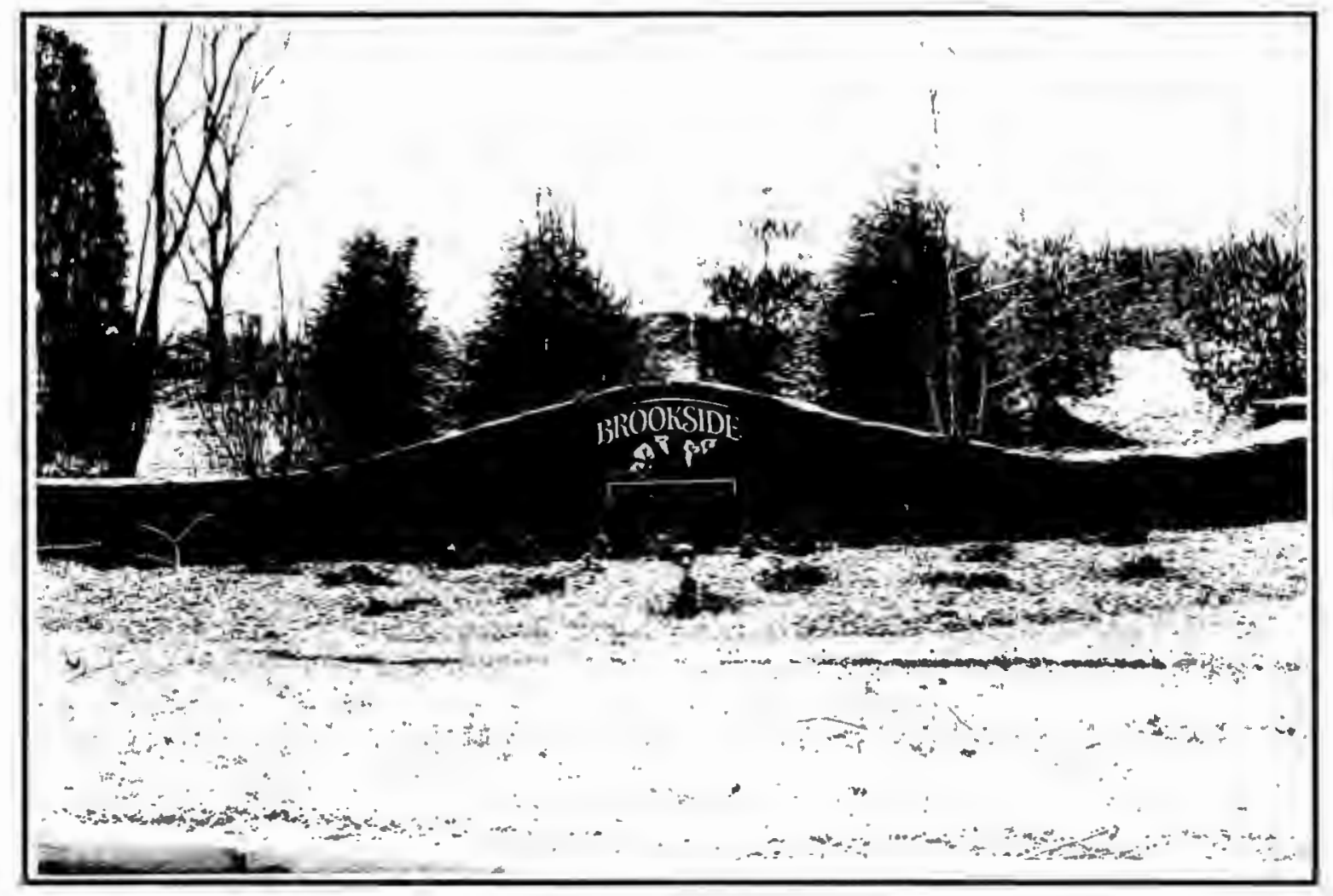

Figure 6. Entrance at Brookside. The developer Mr. Baker hopes the homeowner's association will maintain the sign.

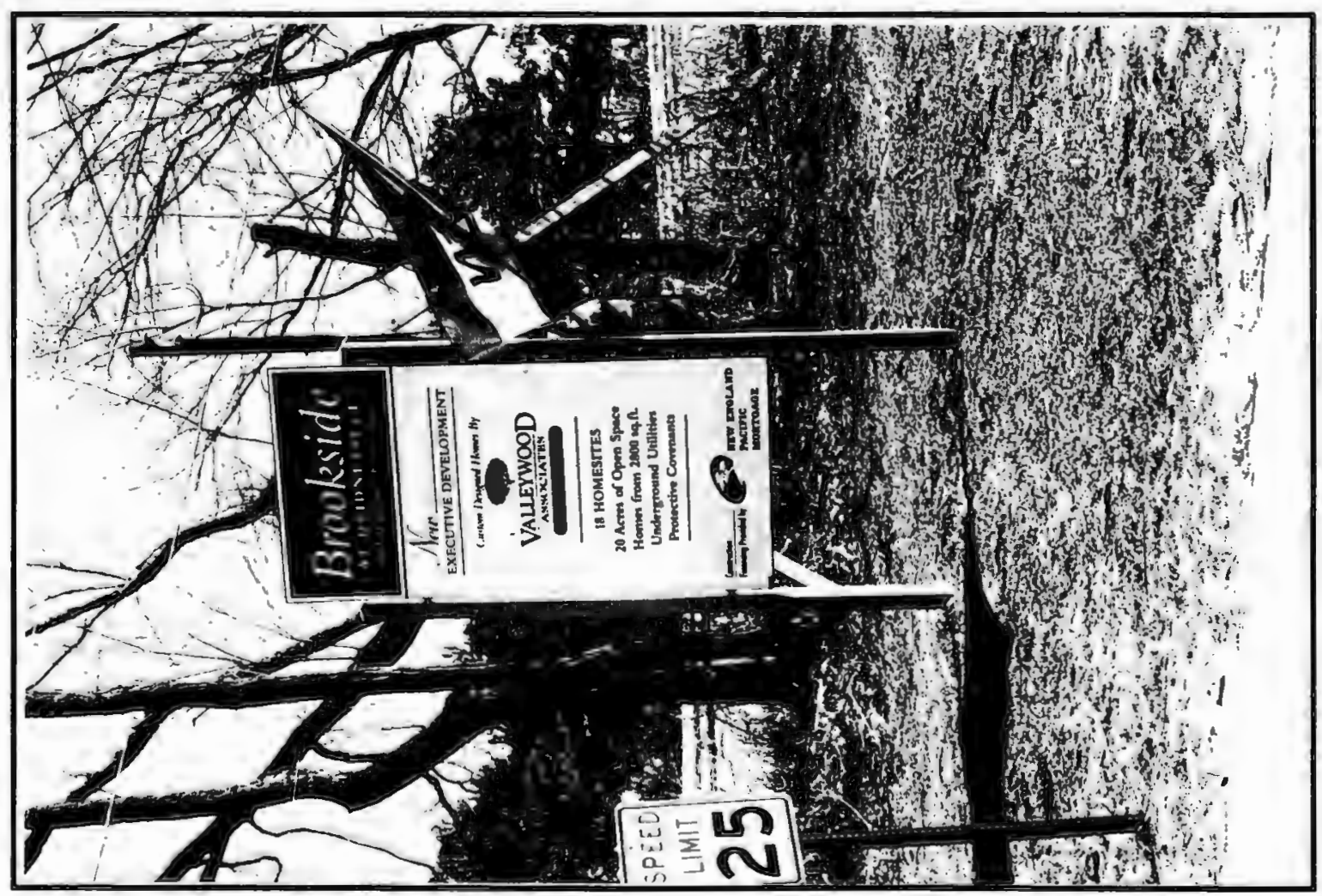

Figure 7. Note the marketing approach. Executive dev'elopment, protective covenants, and open space are selling points. 


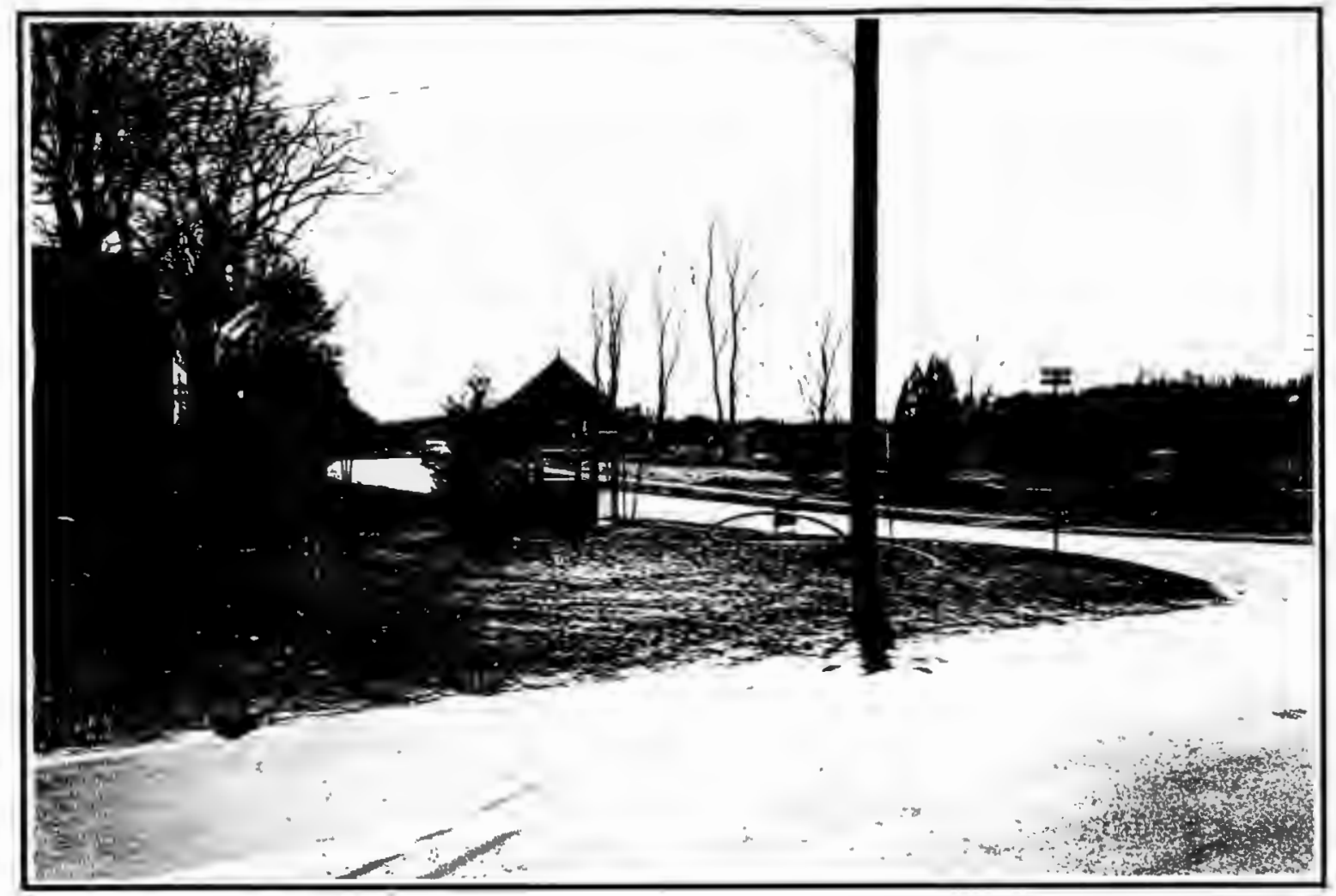

Figure 8. Entrance at Brookside. The gazebo is a plus. Note lack of trees due to former agricultural use.

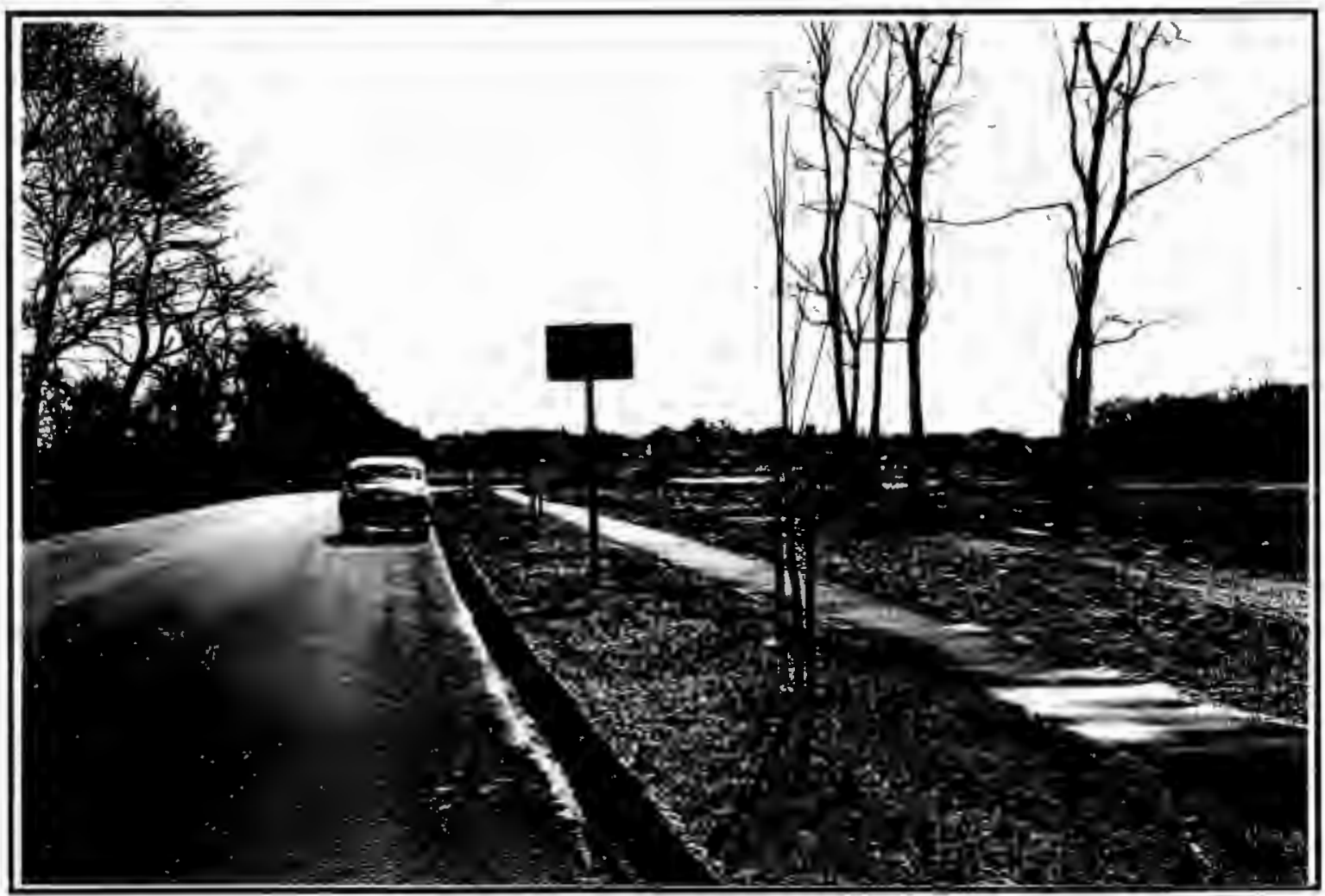

Figure 9. The mandatory homeowner's association sign. Note that the area to the right will be a house lot. 


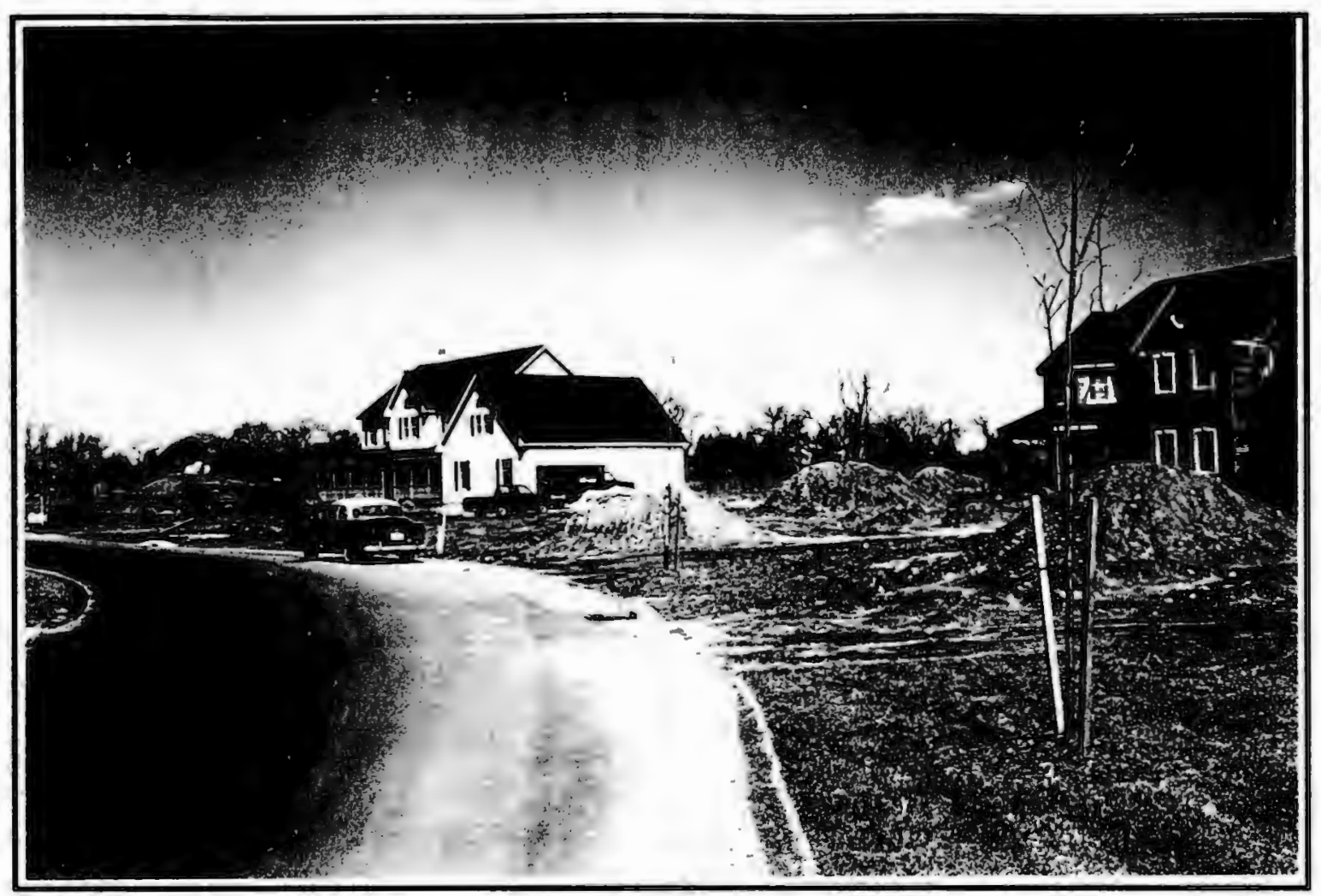

Figure 10. Even though it is a cluster development, Brookside still uses large frontages to give the effect of a traditional large-lot development.

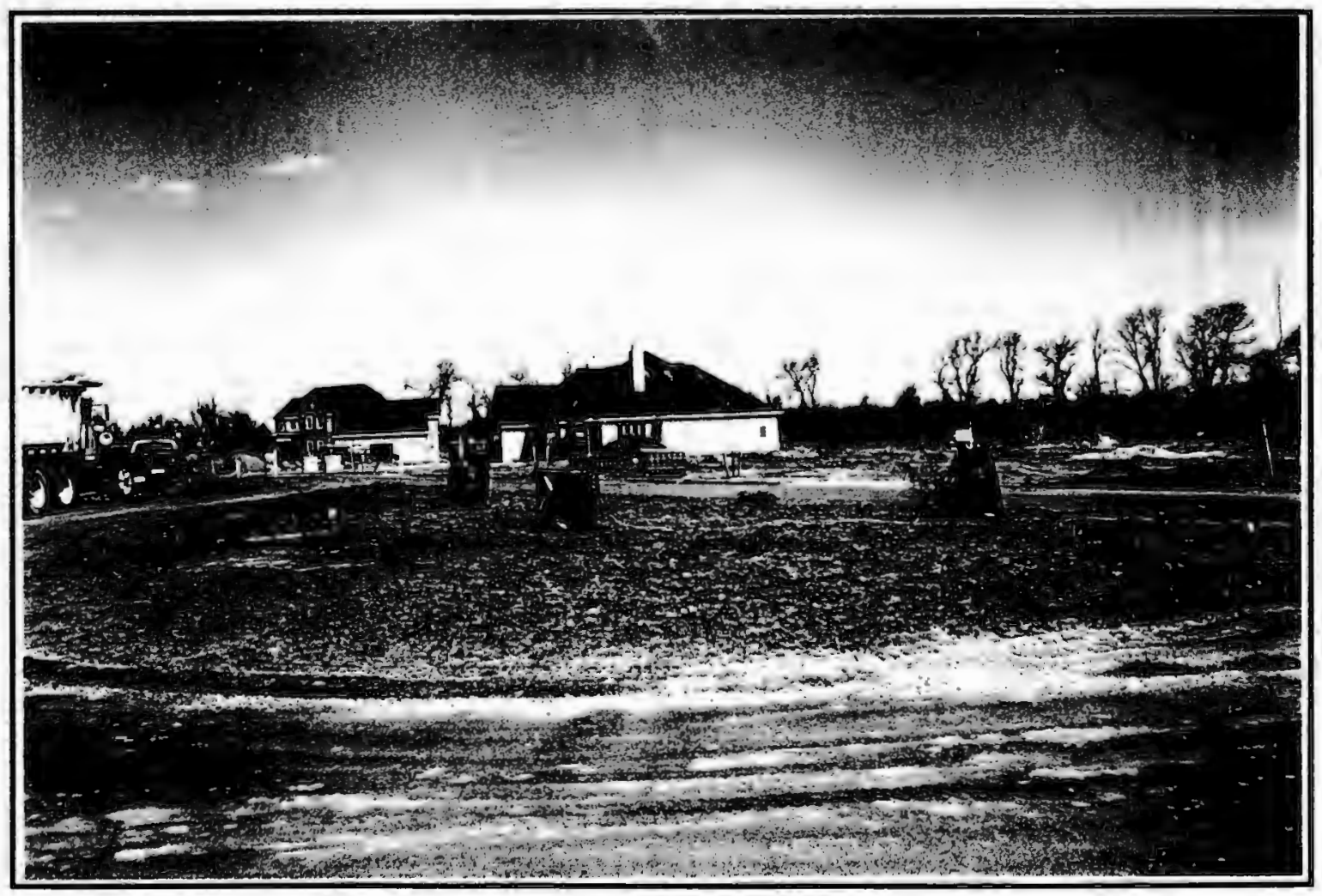

Figure 11. Brookside has very large custom-built homes in the $\$ 400,000-\$ 450,00$ range. 


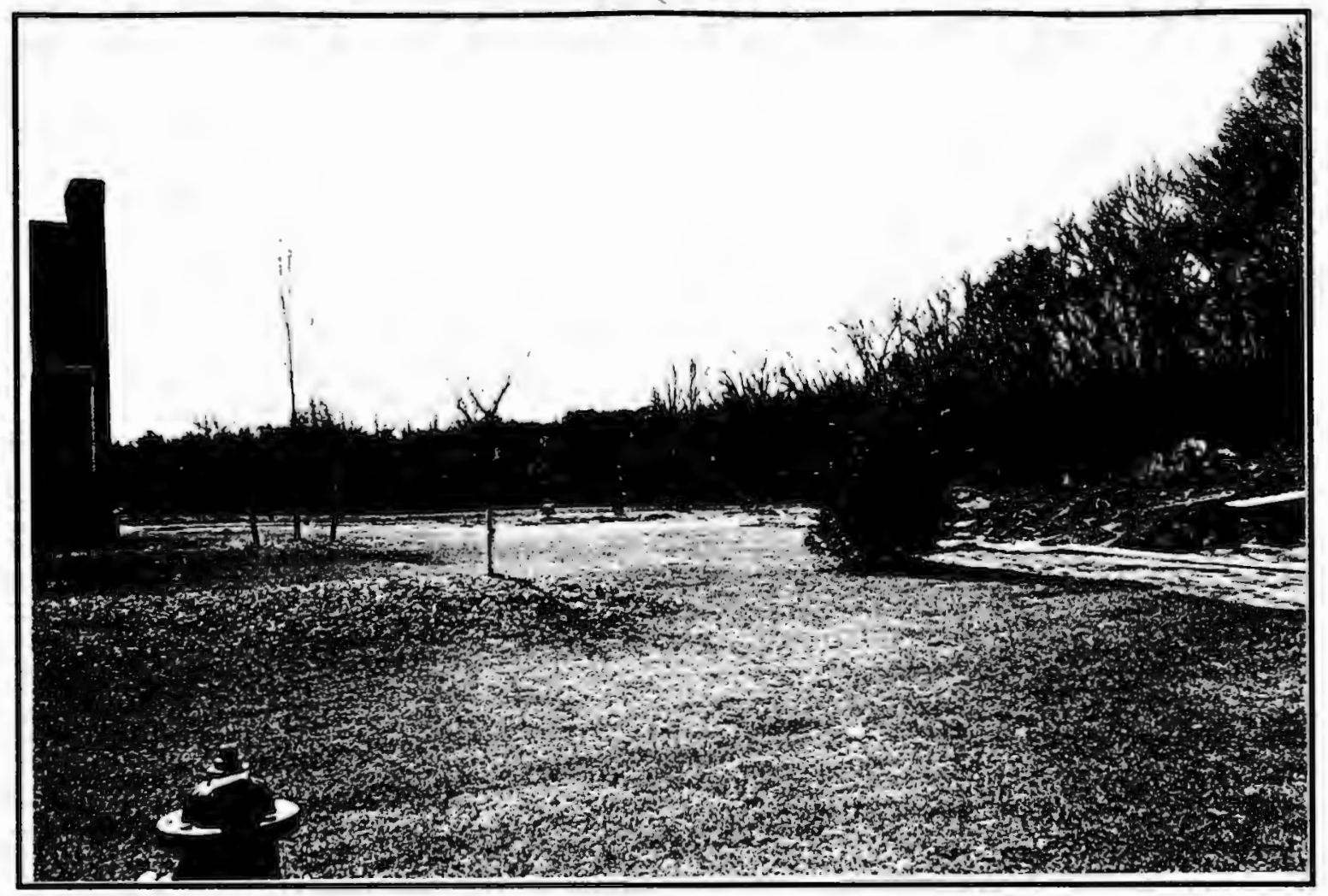

Figure 12. Open space in the western part of the site. It is not clear where the common open space boundary is.

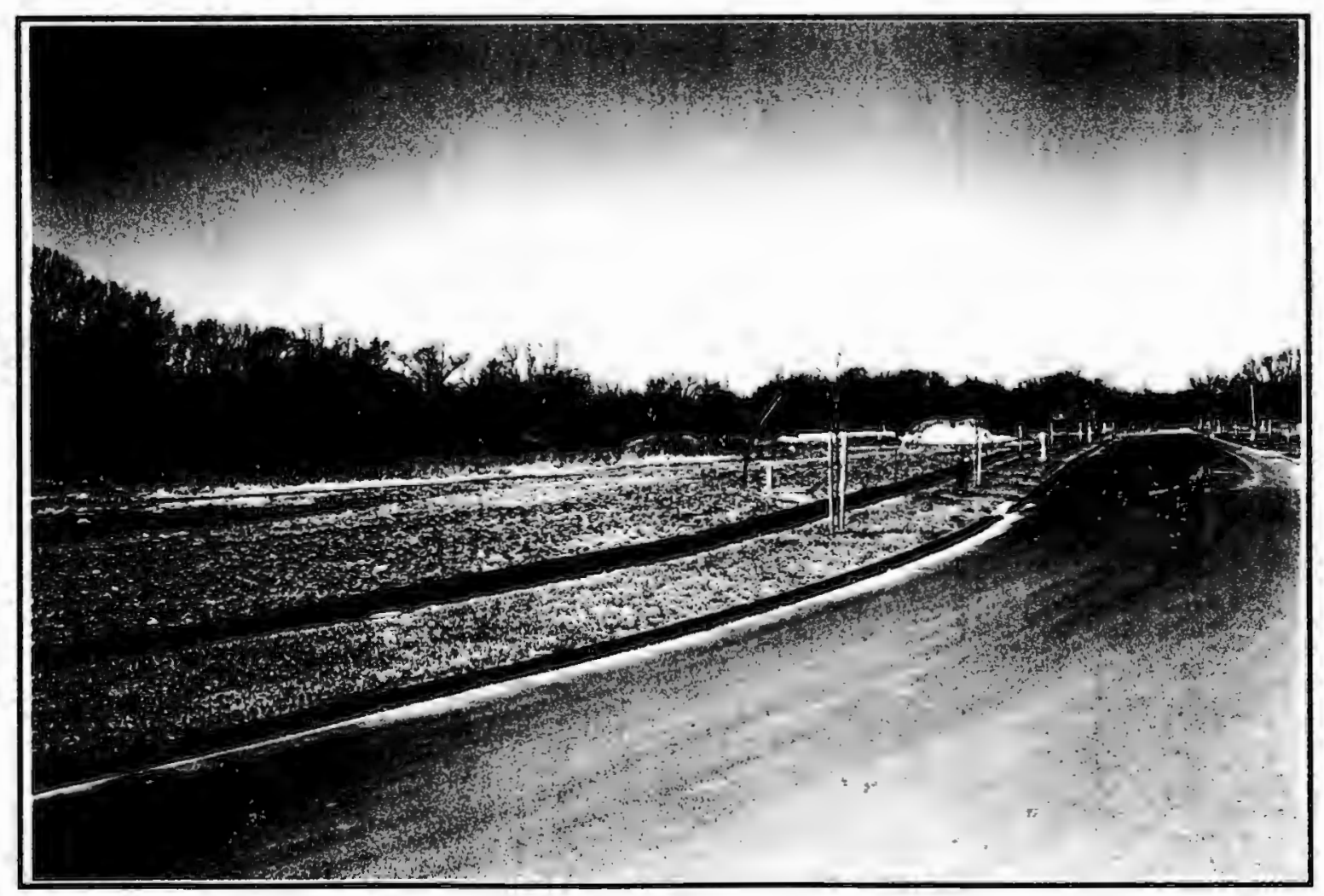

Figure 13. The site is long and thin, limiting design possibilities. 


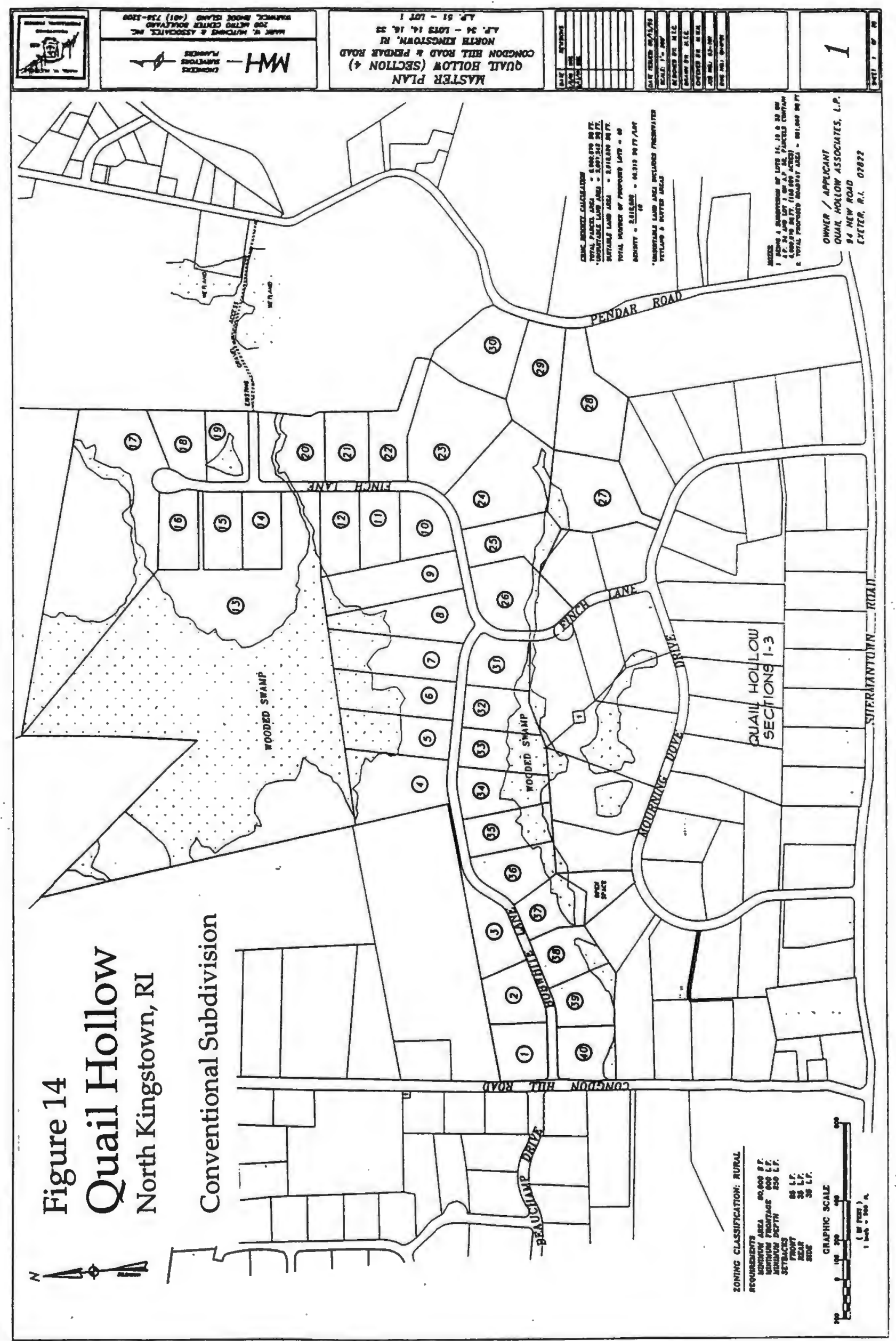




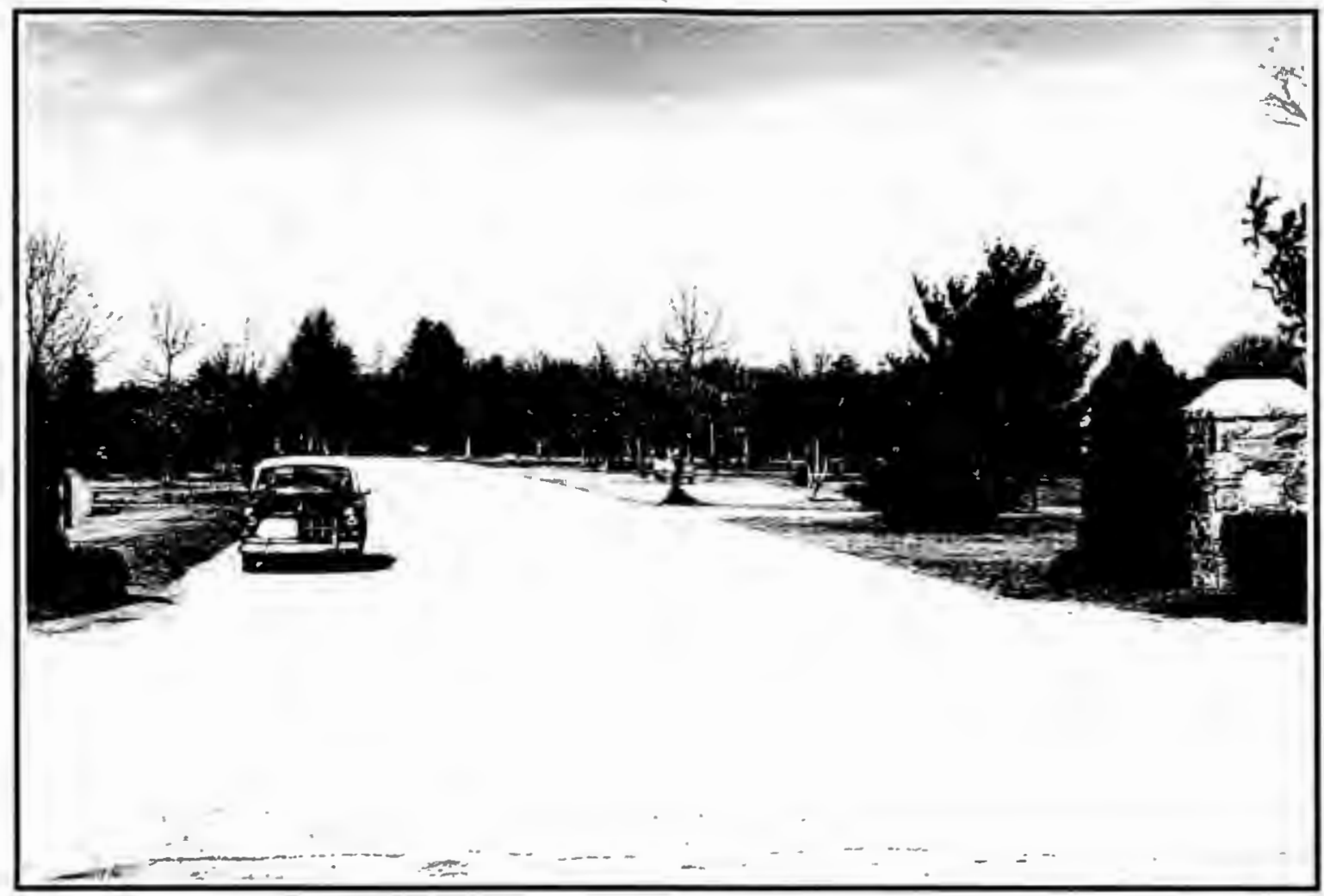

Figure 15. Entrance to Quail Hollow. This gives a good idea of house types and sizes. Note that the trees were moved from other areas on the site with a "tree spade."

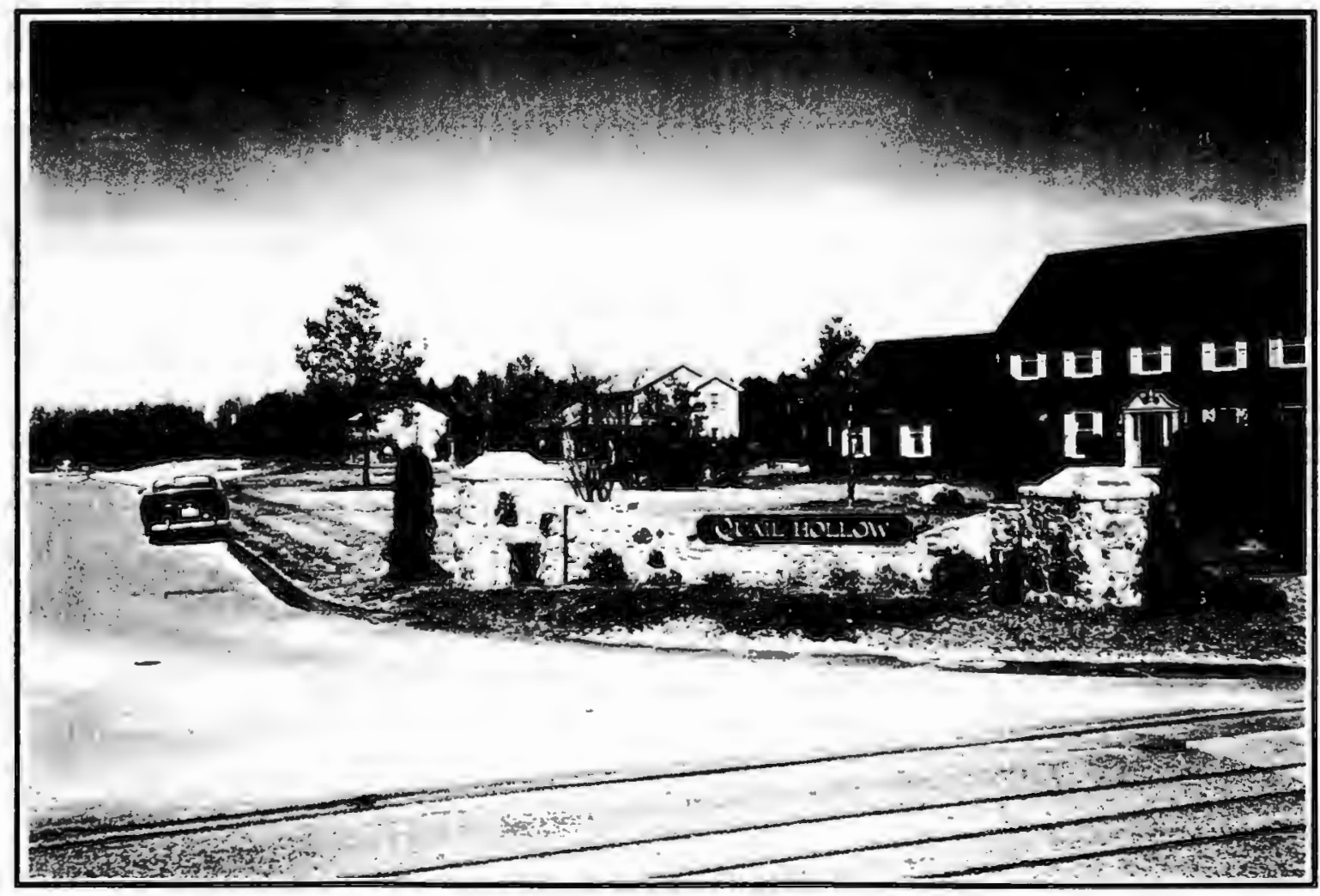

Figure 16. Entrance of Quail Hollow. Note the very large setbacks and lawn areas. I just missed getting a shot of the "Lawn Doctor" truck in a resident's driveway. 


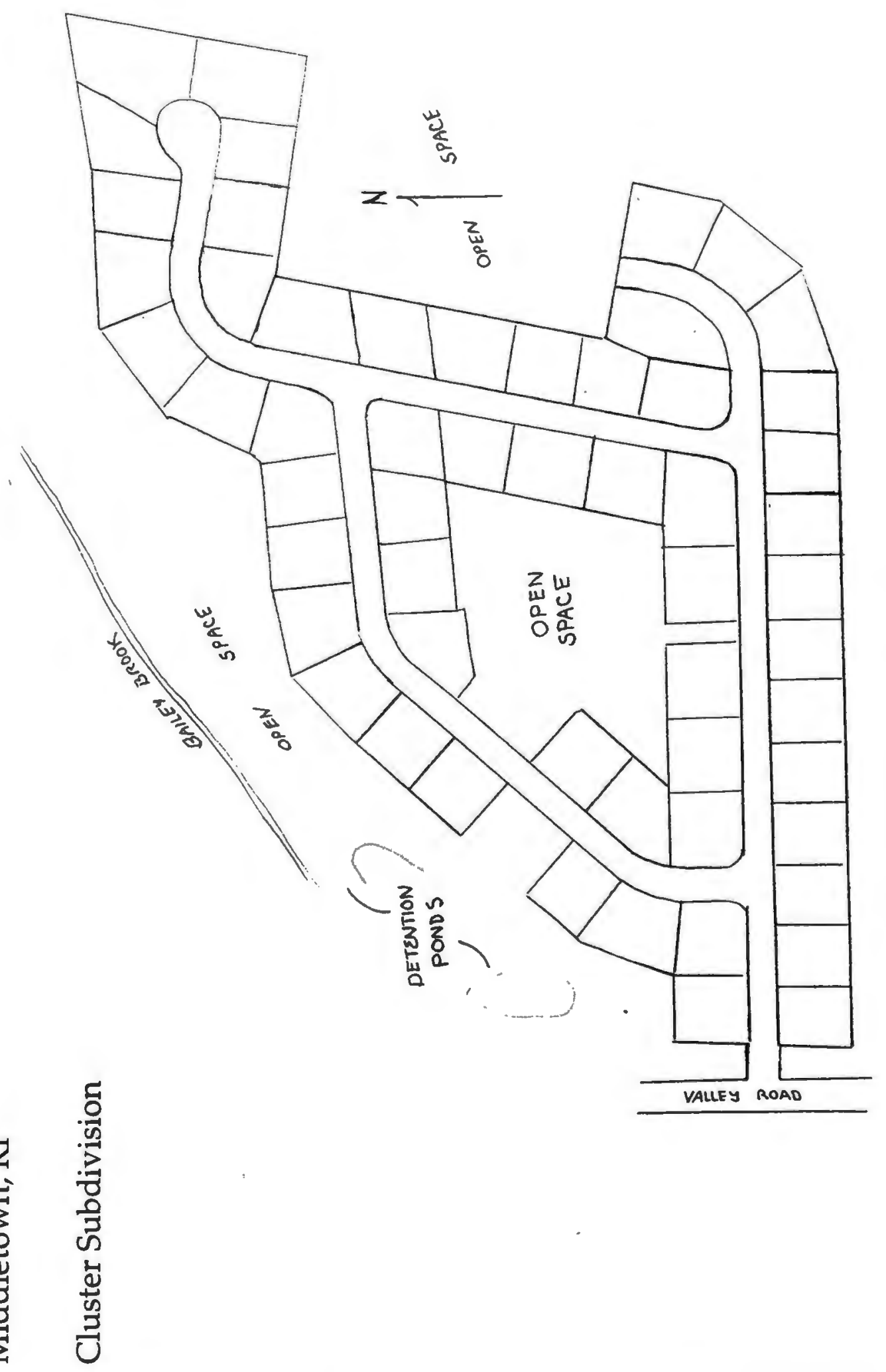




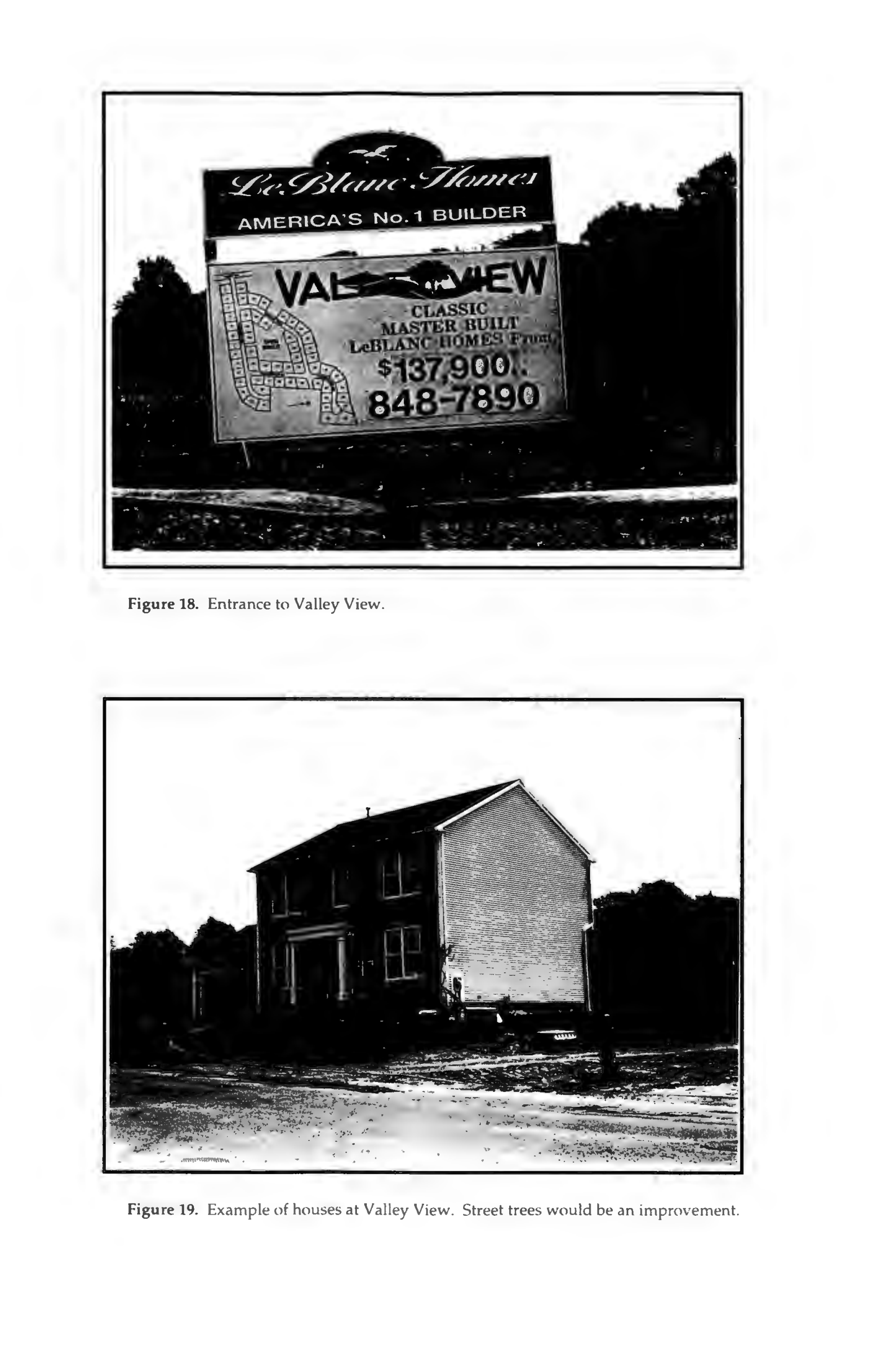




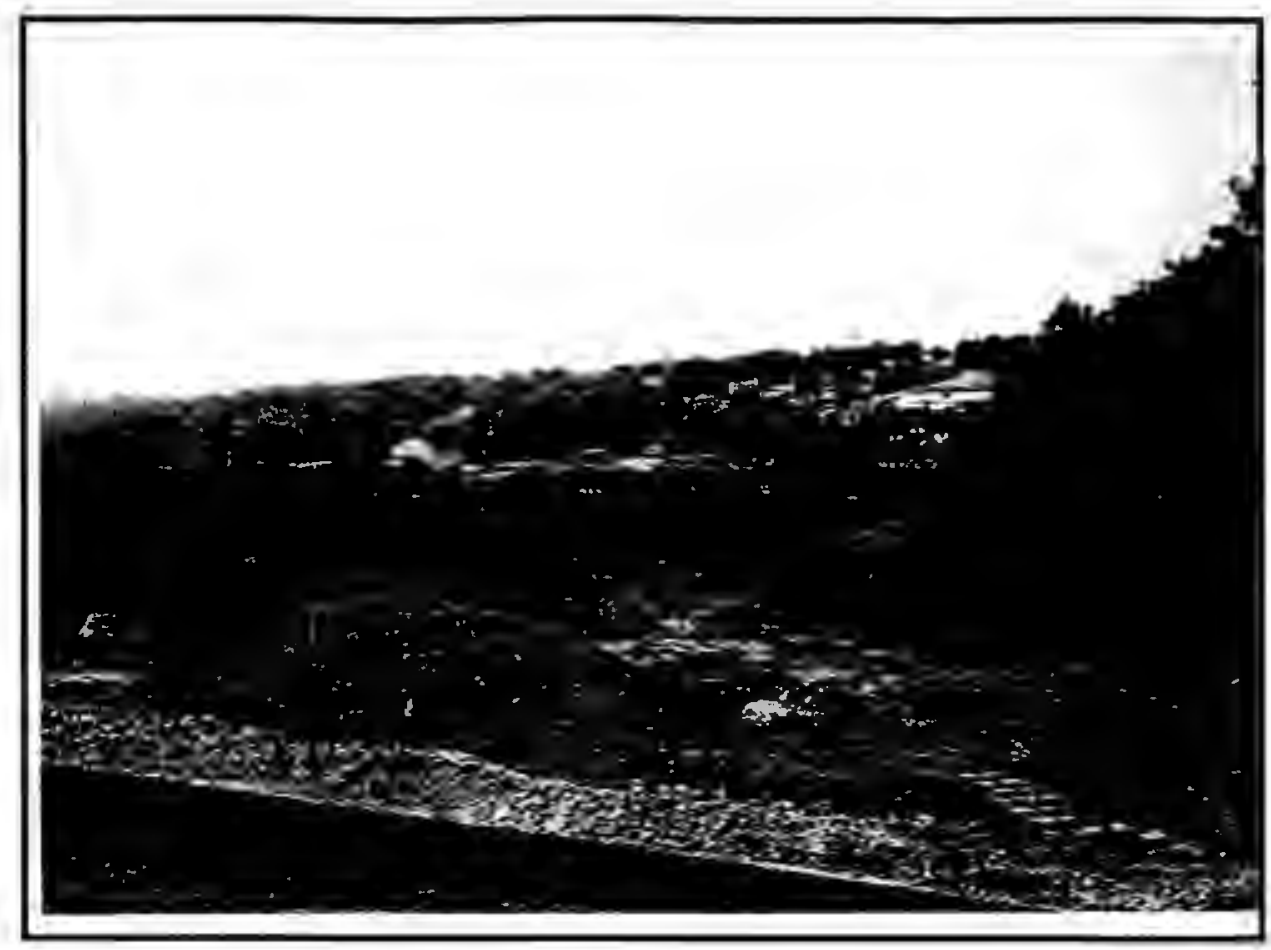

Figure 20. The valley viewed from "Valley View."

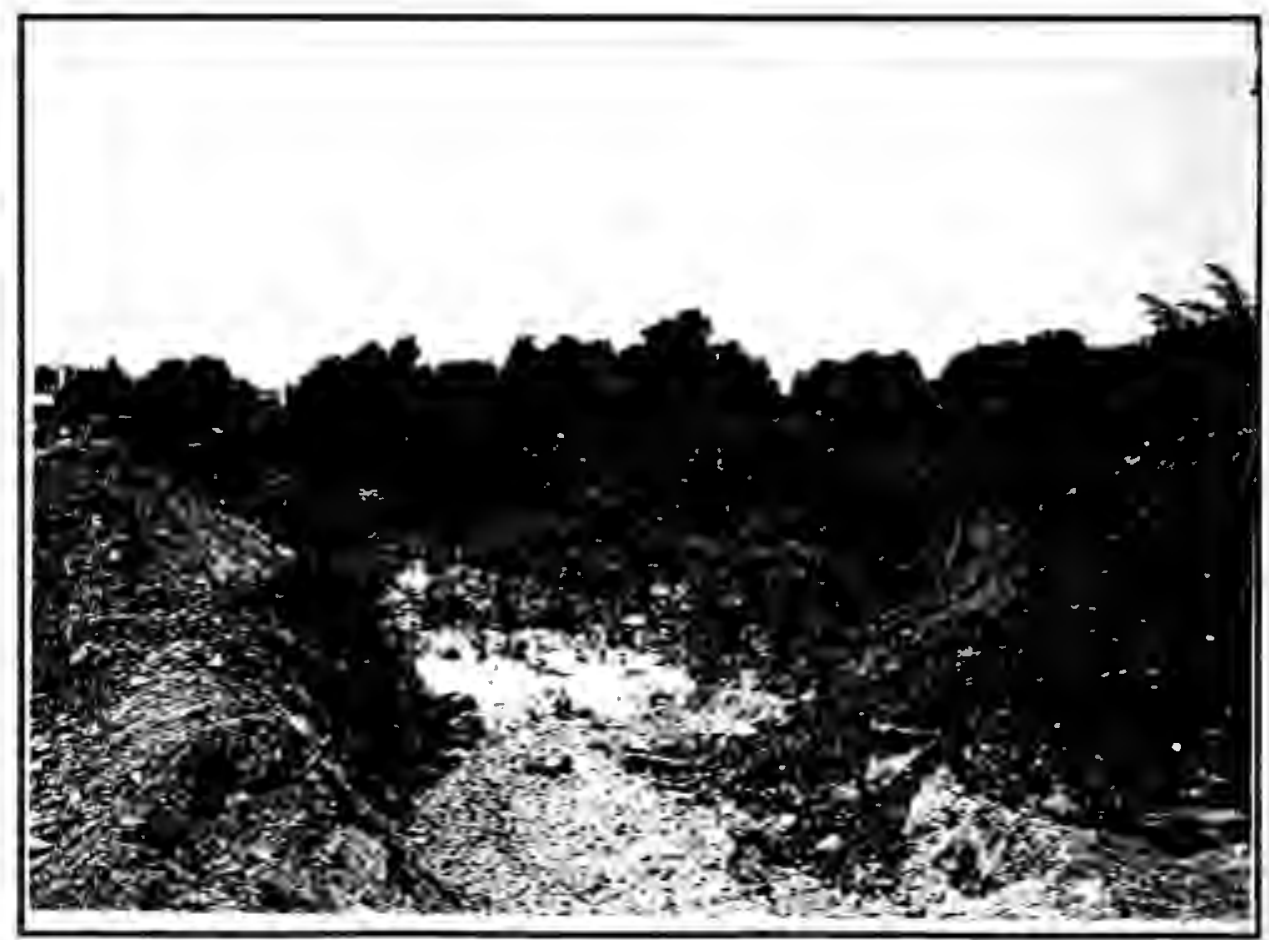

Figure 21. Valley View. Riverbank wetland along the east branch of Bailey Brook. 


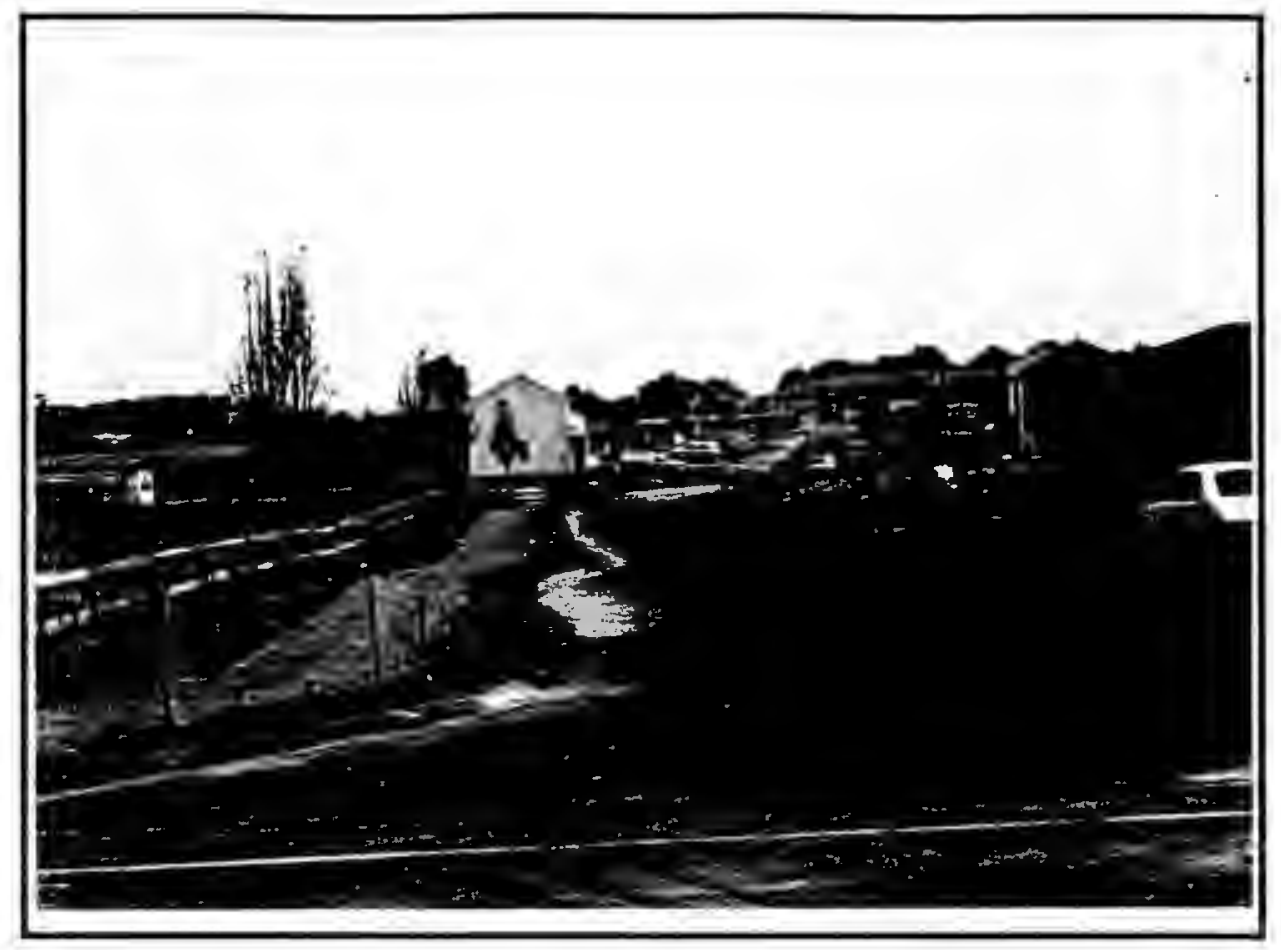

Figure 22. View of entrance of Valley View from Valley Road.

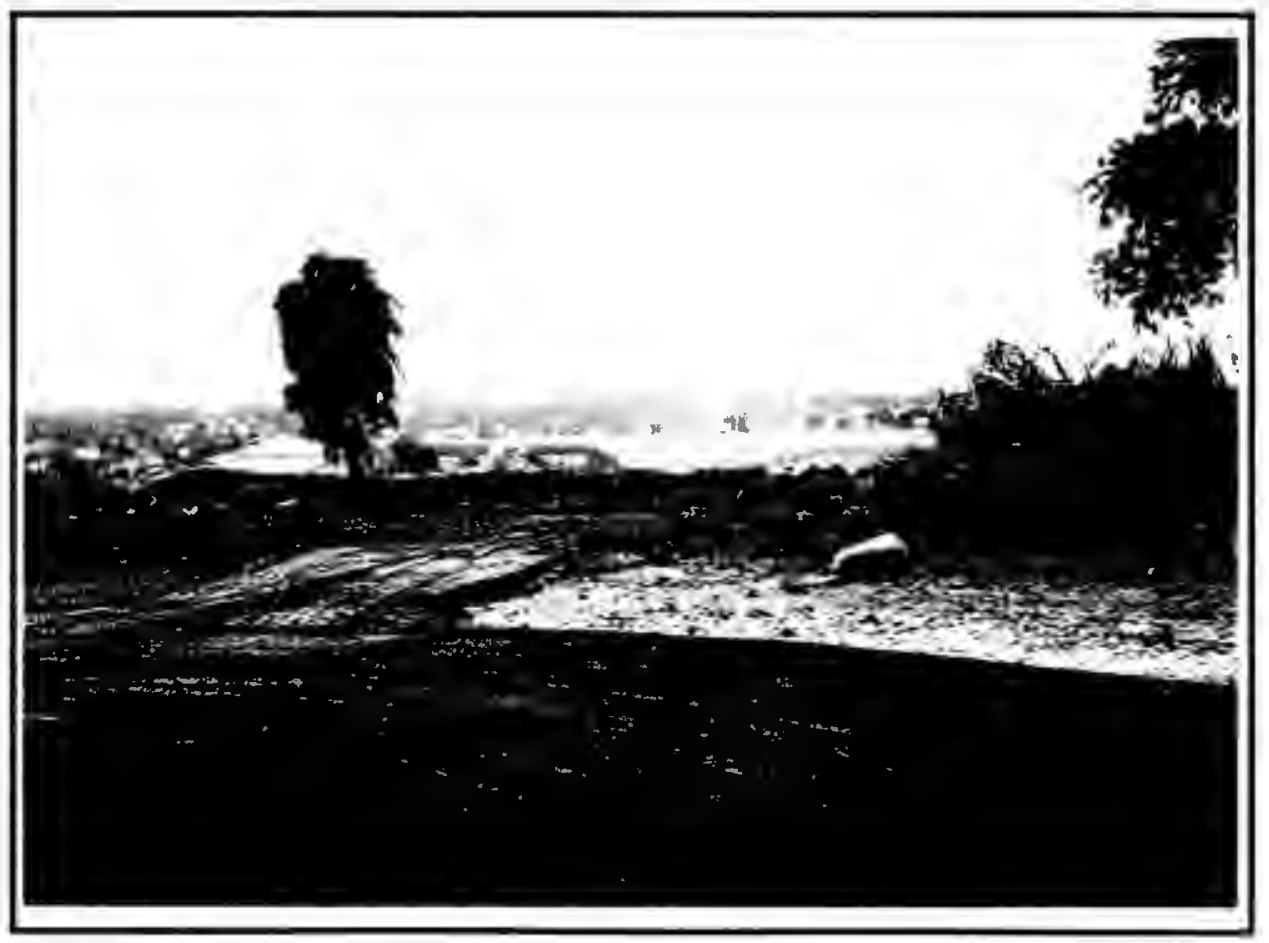

Figure 23. Valley View. It looks like the developer is trying to save any mature trees. 


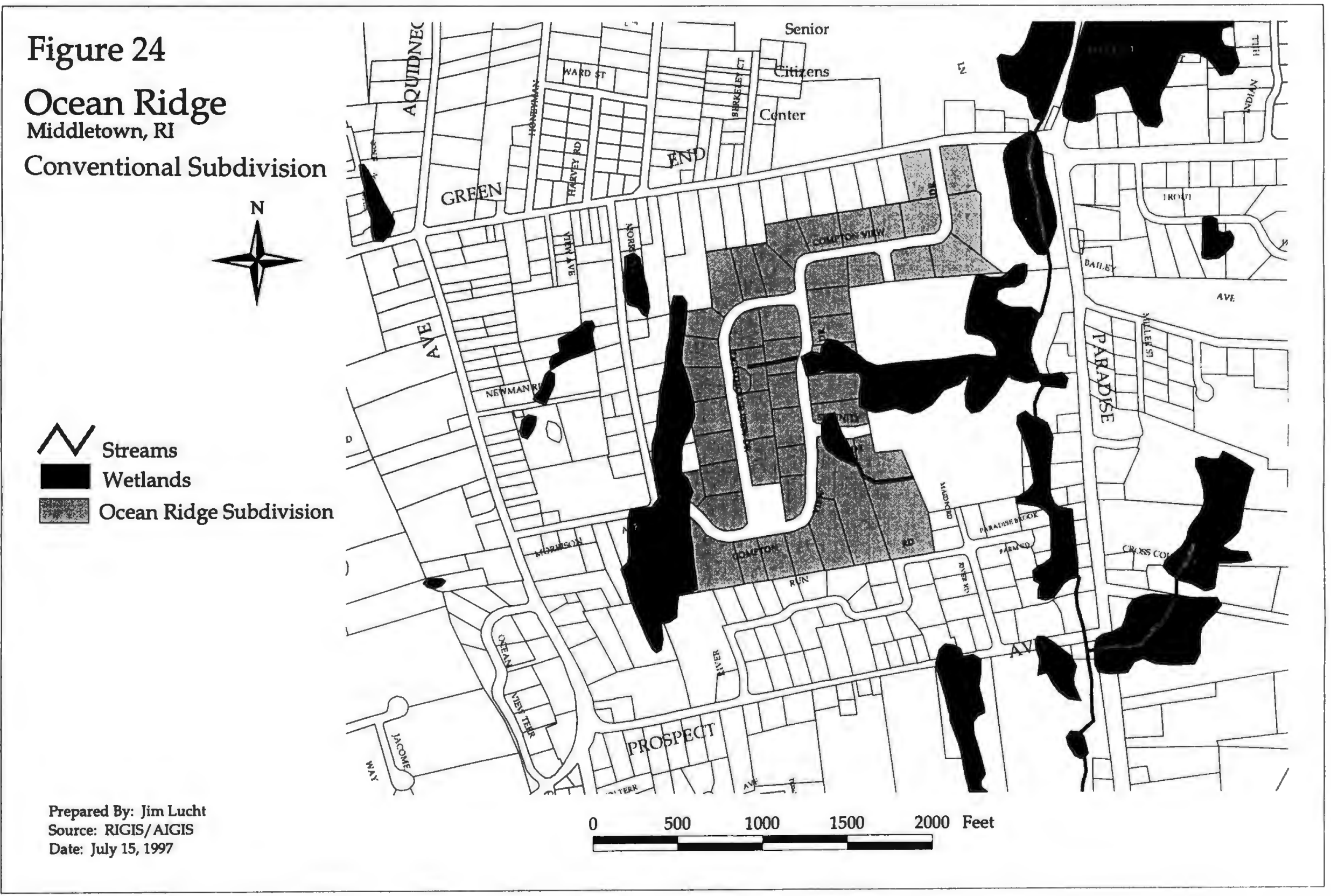




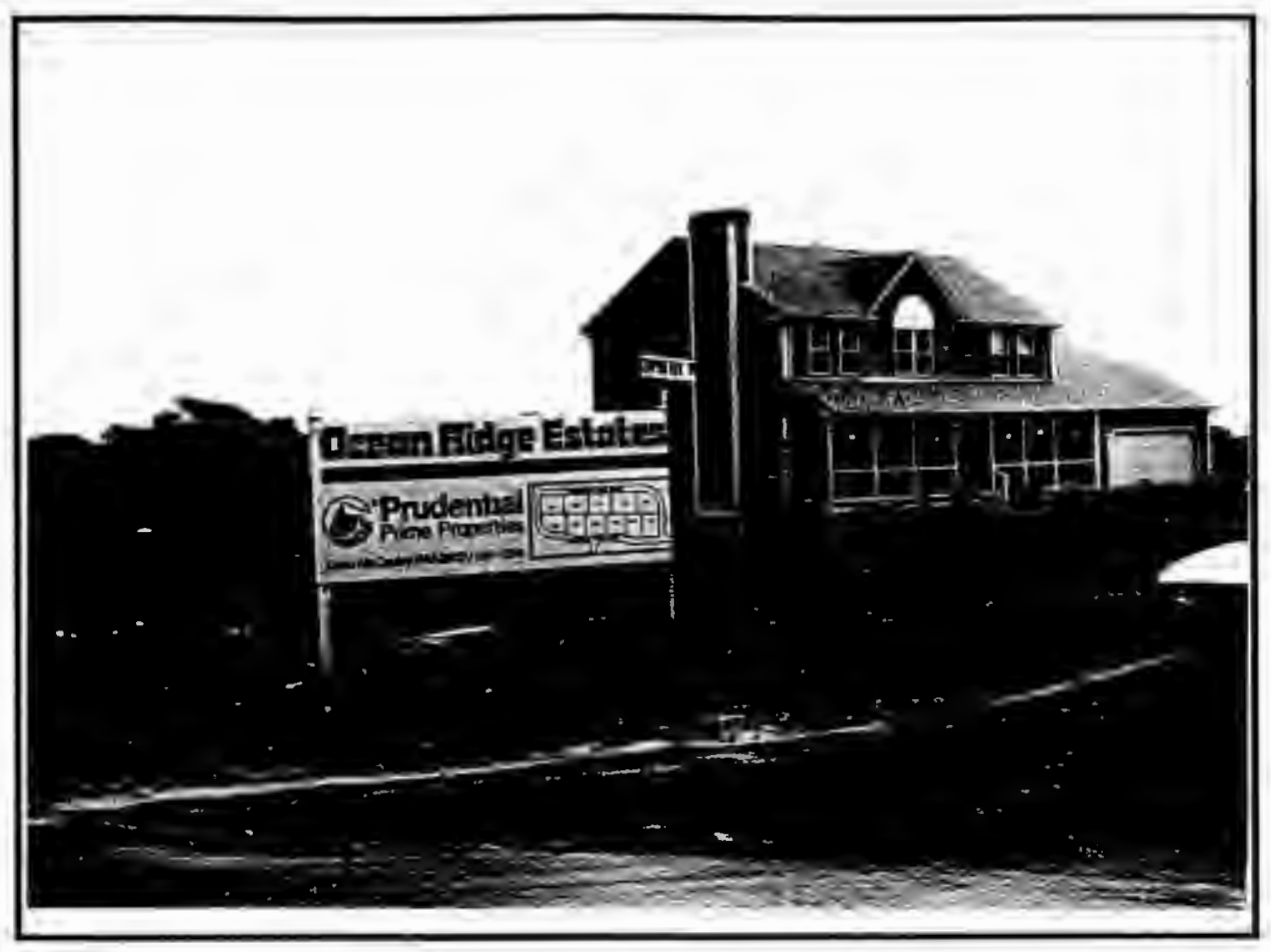

Figure 25. Entrance of Ocean Ridge showing a typical house. Picket fence is a nice touch.

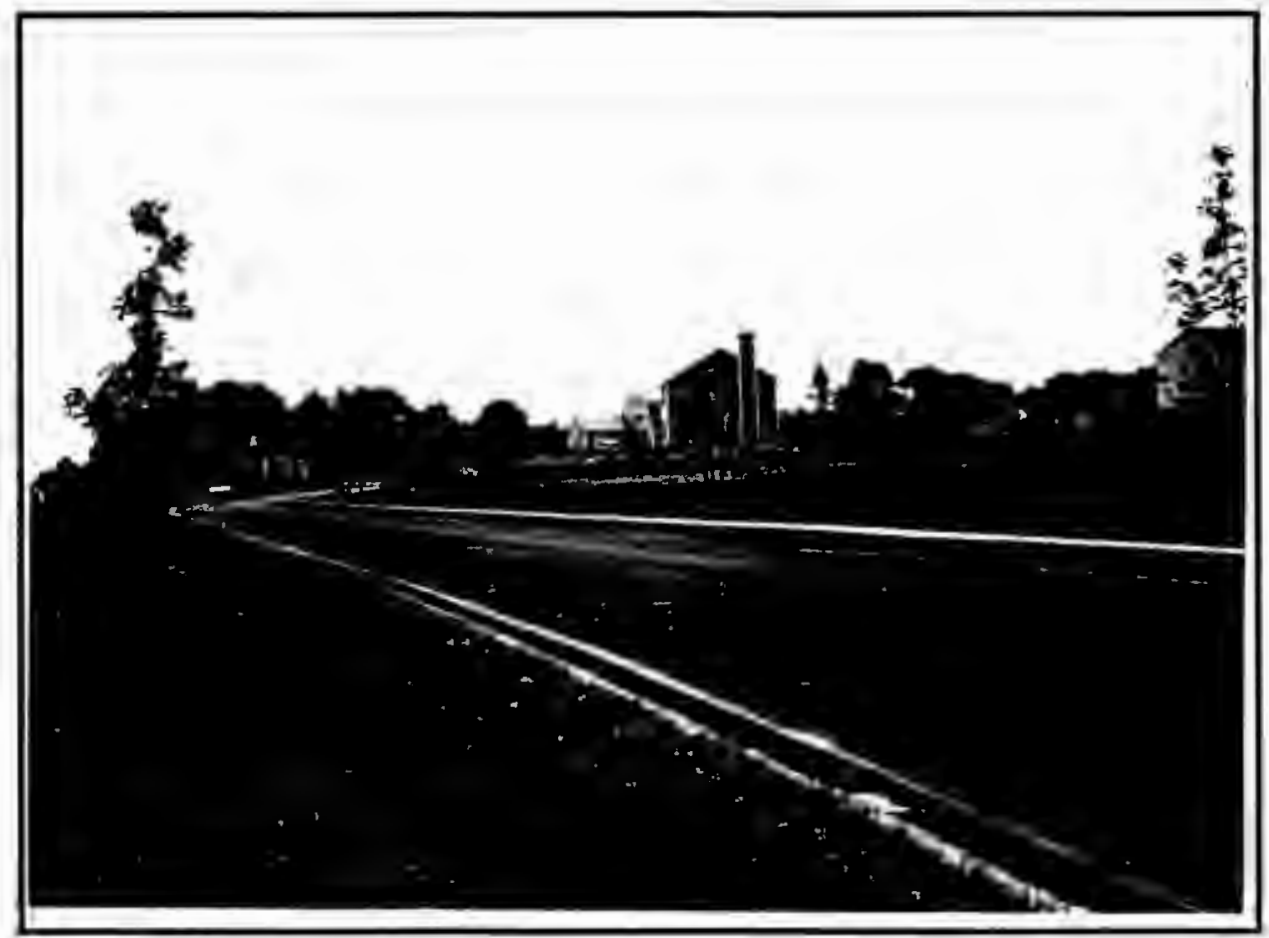

Figure 26. View of Ocean Ridge from the north entrance. R-40 zoning on this landscape produced large lawns with the conventional subdivision layout. 


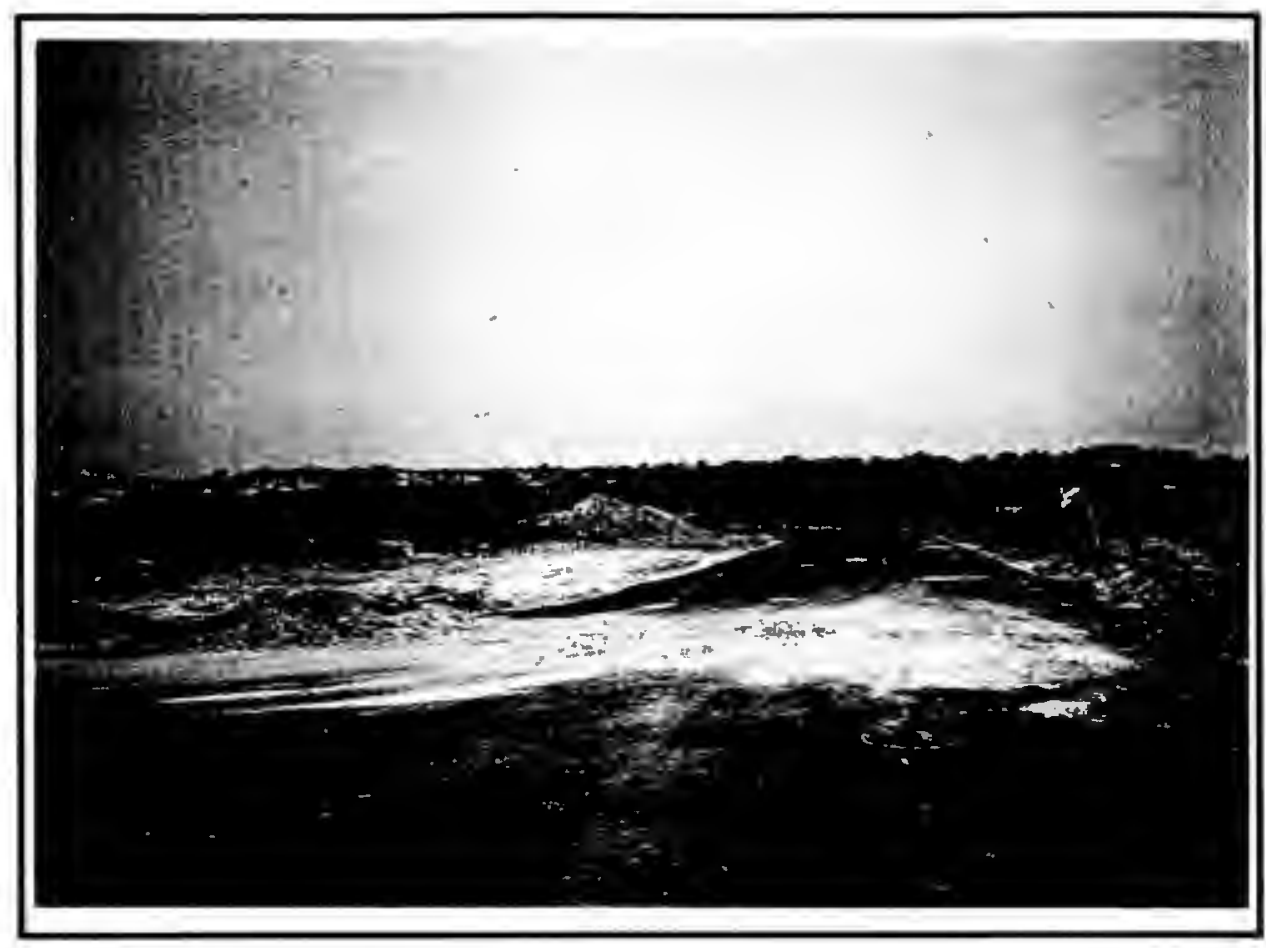

Figure 27. Looking south from south end of Ocean Ridge. Well-developed landscape in the background.

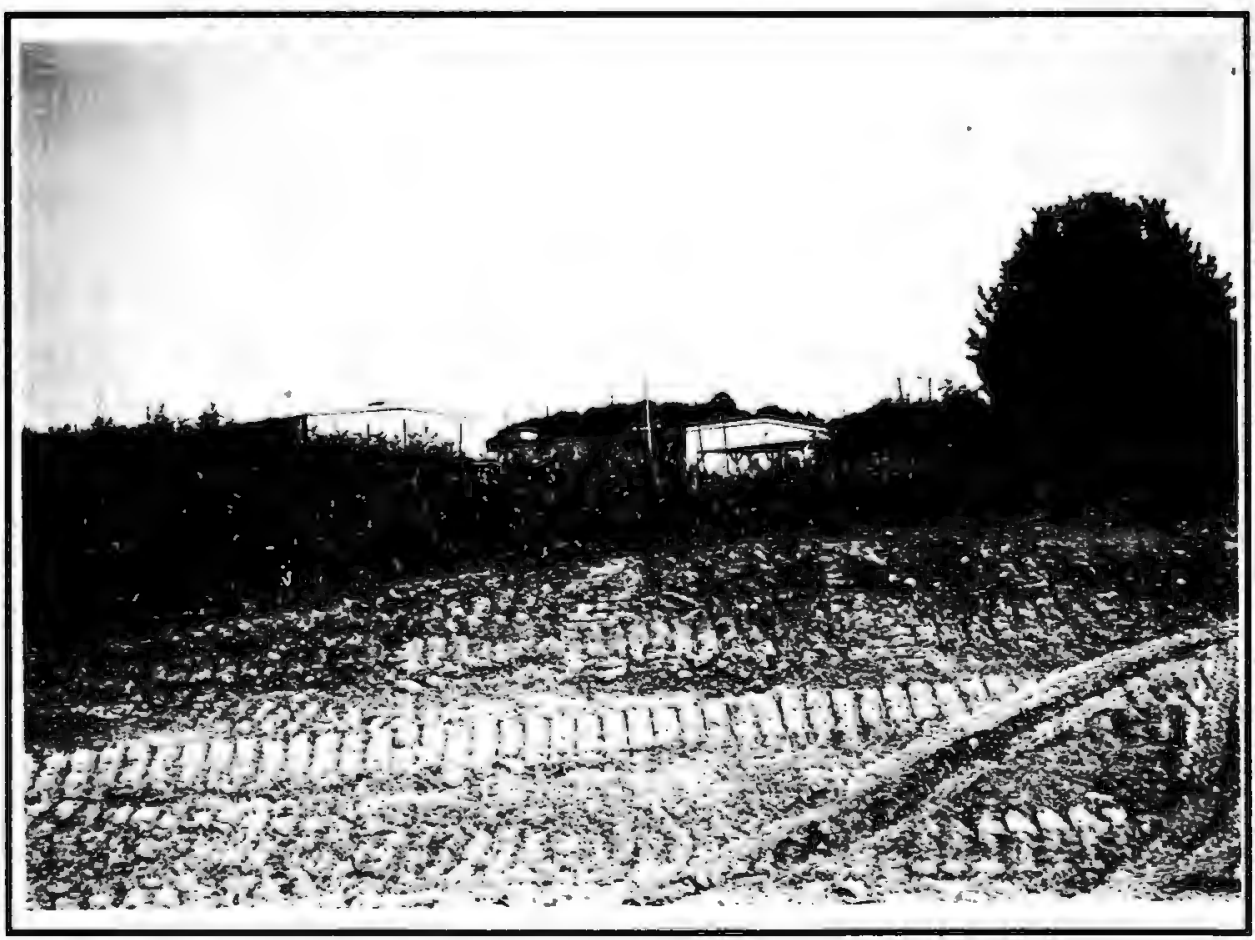

Figure 28. Commercial development to the east of Ocean Ridge. Needs better buffering. 


\section{REFERENCES AND BIBLIOGRAPHY}

*Arendt, Randall. 1997. "Basing Cluster Techniques on Development Densities Appropriate to the Area." Journal of the American Planning Association, 63: 137145 .

Planner's Press.

1994. Rural by Design: Maintaining Small Town Character. APA 1996. Conservation Design for Subdivisions: A Practical Guide for Creating Open Space Networks. Island Press.

*Armstrong, Melissa. 1992. "A Comparison of Private Development Costs." Planning and Zoning News, American Planning Association. (May).

*Audirac, Ivonne, Anne H. Sherman, and Marc T. Smith. 1990. "Ideal Urban Form and Visions of the Good Life." Journal of the American Planning Association, 57: $470-482$.

. 1991. Neo-traditionalism and Return to Town Life: Postmodern Placebo or Remedy for Metropolitan Malaise? Paper presented at the Joint ACSP/AESOP Conference, Oxford, England (July).

Baker, Michael. 1997. Developer. Personal interview with James A. Lucht, July 7. North Kingstown, RI.

*Ben-Joseph, Eran. 1995. "Changing the Residential Street Scene: Adapting the Shared Street Concept to the Suburban Environment." Journal of the American Planning Association 61: 504-516.

"Bookout, Lloyd W. and James W. Wentling. 1988. "Density by Design." Urban Land, June.

Boucher, Frank. 1997. Steel erector/ developer. Telephone interview with James A. Lucht, July 21 . Narragansett, RI.

Bowers, Deborah. 1995. "Farmland Preservation and Clustering: How do they Mix?" Farmland Preservation Report, 5 (10), 1-5.

Breheny, Michael. 1991. Sustainable Development and Urban Form: The Contradictions of the Compact City. Paper presented at the AICP's Planner's Training Service Conference on Neo-Traditional Town Planning, Newport Beach, California, June 27-28. 
Bussel, Abby and Thomas Fisher. 1993. "NIMBY." Progressive Architecture, 74 (9): 88-91.

*Canton, NJ Township Planning Services Division. 1993. Cluster Development: Issues and Alternatives.

Calthorpe, Peter. 1993. The Next American Metropolis: Ecology, Community, and the American Dream. New York: Princeton Architectural Press.

Cohen, Marilyn. 1997. Planning Director, North Kingstown RI. Personal interview with James A. Lucht, June 24. North Kingstown, RI.

Cote, David. 1997. Developer. Personal interview with James A. Lucht, June 18. North Kingstown, RI.

*Corser, Susan Ernst. 1994. "Preserving Rural Character Through Cluster Development." Planning Advisory Service Memo, July. Chicago: Planner's Press.

Crevero, Robert. "Planned Communities, Self Containment, and Commuting: A Cross-National Perspective." Urban Studies, 32: 1135-1161.

*Daniels, Thomas L. 1997. "Where Does Cluster Zoning Fit in Farmland Protection?" Journal of the American Planning Association, 63: 129-136.

Dear, Michael. 1992. "Understanding and Overcoming the NIMBY Syndrome." Journal of the American Planning Association, 58: 288-301.

Dear, Michael, and G. Laws. 1986. "Anatomy of a Decision: Recent land Use Zoning Appeals and Their Effect on Group Home Location in Ontario." Canadian Journal of Community Mental Health, 5 (1): 5-17.

Desmond, Michael. 1997. Planning Board Chairman, North Kingstown RI. Personal interview with James A. Lucht, June 20. Providence, RI.

Dobson, Jim. 1997. Former Planning Board Chairman, North Kingstown RI. Personal interview with James A. Lucht, June 20. North Kingstown, RI.

*Duany, Andres and Elizabeth Plater-Zyberk. 1992. "The Second Coming of the American Small Town." The Wilson Quarterly, Winter, 19-50.

"Eccleston, William. 1997. "The Rural Ravage of Cluster Zoning." Editorial in The Providence Journal. July 27, 1997. 
*Fishman, Robert. 1987. Bourgeois Utopias. Basic Books.

Frank, James E. 1989. The Costs of Alternative Development Patterns: A Review of the Literature. Washington, DC, The Urban Land Institute.

Forsyth, Ann. 1997. "Five Images of a Suburb." Journal of the American Planning Association, 63: 45-60.

Freudenburg, William R. and Susan K. Pastor. 1992. "NIMBY's and LULU's: Stalking the Syndromes." Journal of Social Issues, 48 (4): 39-63.

Gale, C., C.F.Ns, and L. Rosenblood. 1988. "Neighborhood Attitudes Towards Group Homes for People With Mental Handicaps." Mental Retardation and Learning Disabilities Bulletin, 16: 7-26.

Gilstein, Robert. 1997. Town Planner, Portsmouth, RI. Statements made at January 1997 meeting with Portsmouth Town Council on "Residential Open Space Development Ordinance."

Green, Brian M. and Yda Schreuder. 1991. "Growth, Zoning, and Neighborhood Organizations: Land Use Conflict in Wilmington, DE." Journal of Urban Affairs, 13 (1): 97-110.

Hall, Peter. 1989. "The Turbulent Eighth Decade: Challenges to American City Planning." Journal of the American Planning Association, 55: 275-282.

* _ 1988. Cities of Tomorrow: An Intellectual History of Urban Planning and Design in the Twentieth Century. Cambridge: Basil Blackwell.

"Handy, Susan. 1991. "Neo-Traditional Development: The Debate." Berkeley Planning Journal, 6: 135-144.

*Hanke, Byron R. et al. 1974. The Homes Association Handbook. Washington, DC: Urban Land Institute, Technical Bulletin No. 50.

Heyer, Fred. 1990. Preserving Rural Character. PAS 429. American Planning Association.

*Jackson, Kenneth T. 1985. Crabgrass Frontier: The Suburbanization of the United States. New York: Oxford University Press

Kaplan, Sam Hall. 1990. "The Holy Grid: A Skeptic's View." Planning (May). 
Kennedy, David J. 1995. "Residential associations as state actors: regulating the impact of gated communities on non-members." Yale Law Journal, 105: 761-793.

*Knack, Ruth Eckdish. "Selling Cluster." Planning, September 1990, pp. 4-10.

"Knack, Ruth Eckdish. "The One-Acre Habit is Hard to Break." Planning, August, 1991, pp. 8-11.

*Lacy, Jeff. 1990. An Examination of Market Appreciation for Cluster Housing With Permanent Open Space. Center for Rural Massachusetts, University of Massachusetts Department of Landscape Architecture and Regional Planning. From Web Site: www-unix.oit.umass.edu/ rural/LacyMarket.html.

Lake, Robert W. 1993. "Rethinking NIMBY." Journal of the American Planning Association, 59: 87-92.

LeBlanc, Larry. 1997. Developer. Telephone interview with James A. Lucht, June 19. Narragansett, RI.

Listoken, David and Carole Walker. 1989. The Subdivision and Site Plan Handbook. New Brunswick, NJ: Rutgers.

Livingston County Planning Department. Protect Environmental Agricultural and Rural Landscape (PEARL). November 1991.

Logan, John R. and Gordana Rabrenovic. 1990. "Neighborhood associations: their issues, their allies, and their opponents." Urban Affairs Quarterly, 26 (1): 6895.

McHarg, Ian. 1967. Design With Nature. New York: John Wiley \& Sons, Inc.

National Association of Home Builders. Cost Effective Site Planning. NAHB. Washington, DC; 1986.

Nasar, Jack L. and David A. Julian. 1995 "The Psychological Sense of Community and Neighborhood." Journal of the American Planning Association, 63: 178-184.

Nelson, Arthur C. 1985. "A Unifying view of Greenbelt Influences on Regional Land Values and Implications for Regional Planning." Policy, Growth, and Change, 16(2): 43-48. 
*Neuman, W. Lawrence. 1997. Social Research Methods: Quantitative and Qualitative Approaches. Allyn and Bacon.

Newport Collaborative Architects, Burk Ketcham \& Assoc., Cynthia G. Collins, Esq., and Kim Murdock. 1994-1996. Scituate Reservoir Zoning Project.

Norwood, Ken and Kathleen Smith. 1995. Rebuilding Community in America. Shared Living Resource Center.

O'Looney, John. 1993. "Framing a social market for community responsibility: governing in the age of NIMBY's and LULU's." National Civic Review, 82 (1): 4463.

Phillips, J. Brian. 1989. "Private Cities." The Freeman, 39 (3): 113-115.

Popper, Frank J. 1984. "Rural Land Use Policies and Rural Poverty." Journal of the American Planning Association, 52: 326-334.

*Porter, Douglas R. et al. 1988. Flexible Zoning: How it Works. Urban Land Institute.

*Porterfield, Gerald A. and Kenneth B. Hall, Jr. 1980. The Cluster Subdivision. PAS 356, Planning Advisory Service, American Planning Association.

Rohan, Patrick J. 1996. Zoning and Land Use Controls. New York, New York: Matthew Bender \& Co. Inc.

*Sayer and Morgan. 1995. "Social Research Methods." Sage.

Silvia, Charlie. 1997. Town Planner, Middletown, RI. Personal interview with James A. Lucht, July 7. Middletown, RI.

*Southworth, Michael and Eran Ben-Joseph. 1995. Street Standards and the Shaping of Suburbia. Journal of the American Planning Association 61, 1: 65 - 81.

Stratford, William. 1997. Planning Board Chairman, Middletown, RI. Personal interview with James A. Lucht, July 17. Middletown, RI.

Sutro, Suzanne. 1990. "Reinventing the Village." Planning Advisory Service Report Number 430. Chicago: Planner's Press.

Whitaker, Lee. 1997. Planner, North Kingstown RI. Personal interview with James A. Lucht. June 19. North Kingstown, RI. 
Wright, John B. 1994. "Designing and Applying Conservation Easements." Journal of the American Planning Association, 60: 380-388.

*Wyckoff, Mark A. 1992. "Overcoming Barriers to Effectively Implementing Open Space Zoning." In Planning and Zoning News, 10 (6). May. Lansing Michigan: The Planning and Zoning Center.

Yaro, Robert D. et al. 1988. 1988. Dealing with Change in The Connecticut River Valley. Lincoln Institute of Land Policy.

*Young, Dwight. 1995. Alternatives to Sprawl. Lincoln Institute of Land Policy. 